\title{
Hot Gas Cleanup Test Facility for Gasification and Pressurized Combustion
}

\author{
Quarterly Report \\ October - December 1994
}

February 1995

Work Performed Under Contract No.: DE-FC21-90MC25140

For

U.S. Department of Energy

Office of Fossil Energy

Morgantown Energy Technology Center

Morgantown, West Virginia

By

Southern Company Services, Inc.

Birmingham, Alabama

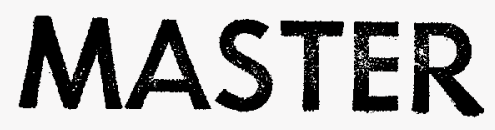




\section{DISCLAIMER}

This report was prepared as an account of work sponsored by an agency of the United States Government. Neither the United States Government nor any agency thereof, nor any of their employees, makes any warranty, express or implied, or assumes any legal liability or responsibility for the accuracy, completeness, or usefulness of any information, apparatus, product, or process disclosed, or represents that its use would not infringe privately owned rights. Reference herein to any specific commercial product, process, or service by trade name, trademark, manufacturer, or otherwise does not necessarily constitute or imply its endorsement, recommendation, or favoring by the United States Government or any agency thereof. The views and opinions of authors expressed herein do not necessarily state or reflect those of the United States Government or any agency thereof.

This report has been reproduced directly from the best available copy.

Available to DOE and DOE contractors from the Office of Scientific and Technical Information, 175 Oak Ridge Turnpike, Oak Ridge, TN 37831; prices available at (615) 576-8401.

Available to the public from the National Technical Information Service, U.S. Department of Commerce, 5285 Port Royal Road, Springfield, VA 22161; phone orders accepted at (703) 487-4650. 


\section{DISCLAIMER}

Portions of this document may be illegible in electronic image products. Images are produced from the best available original document. 


\title{
Hot Gas Cleanup Test Facility for Gasification and Pressurized Combustion
}

\author{
Quarterly Report \\ October - December 1994
}

Work Performed Under Contract No.: DE-FC21-90MC25140

For

U.S. Department of Energy

Office of Fossil Energy

Morgantown Energy Technology Center

P.O. Box 880

Morgantown, West Virginia 26507-0880

By

Southern Company Services, Inc.

800 Shades Creek Parkway

P. O. Box 2625

Birmingham, Alabama 35202-2625

February 1995 


\section{POWER SYSTEMS DEVELOPMENT FACILITY \\ QUARTERLY TECHNICAL PROGRESS REPORT \\ OCTOBER 1 - DECEMBER 31, 1994}

\section{TABLE OF CONTENTS}

\subsection{INTRODUCTION AND SUMMARY}

2.0 REVIEW OF TECHNICAL PROGRESS

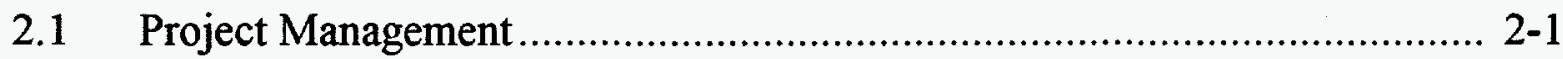

2.2 Phase 1 - Conceptual Design Activities ................................................ 2-2

2.2.1 Task 1.4 Transport Reactor Development Unit ........................... 2-2

2.3 Phase 2 - Detailed Design Activities........................................................ 2-2

2.3.1 Task 2.1 Detailed Design .......................................................... 2-2

2.3.1.1 MWK: PSDF Transport Train ...................................... 2-2

2.3.1.2 FW Team Activities .................................................... 2-2

2.3.1.3 Balance-of-Plant Activities........................................ 2-4

2.3.1.4 Process Hazard Review .............................................. 2-8

2.3.2 Task 2.2 Facility Design Document ............................................ 2-8

2.3.3 Task 2.3 Environmental Permitting and Compliance....................... 2-8

2.3.4 Task 2.4 Particle Characterization and Collection ........................... 2-9

2.3.5 Task 2.5 Particle Control Technologies........................................ 2-11

2.3.6 Task 2.8 Experimental Test Plan ............................................. 2-13

2.4 Phase 3 - Construction, Procurement and Installation ................................. 2-13

2.4.1 Task 3.1 Procurement .............................................................. 2-13

2.4.2 Task 3.3 Construction and Installation .................................. 2-17

2.4.3 Task 3.6 Preparations for Operations ........................................ 2-19

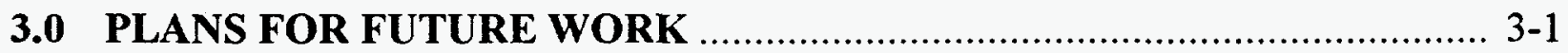


APPENDIX A: FW Detailed Project Schedule

APPENDIX B: Agenda from the FW/SCS Detailed Design Meeting Held on November 15-17, 1994

APPENDIX C: FW APFBC System: Topping Combustor/Gas Turbine Piping System

APPENDIX D: FW APFBC System: Expansion Joints in Lined Pipes D-1

APPENDIX E: FW APFBC System: PCD Temperature. E-1 APPENDIX F: FW APFBC Train: Detailed Component Schedule. F-1 APPENDIX G: WILSONVILLE INTERACTIVE LEARNING SYSTEM: MWK TRAIN FLOWCHARTS. 


\subsection{INTRODUCTION AND SUMMARY}

This quarterly technical progress report summarizes the work completed during the fourth quarter, October 1 through December 31, 1994, under the Department of Energy (DOE) Cooperative Agreement No. DE-FC21-90MC25140 entitled "Hot Gas Cleanup Test Facility for Gasification and Pressurized Combustion." The objective of this project is to evaluate hot gas particle control technologies using coal-derived gas streams. This will entail the design, construction, installation, and use of a flexible test facility which can operate under realistic gasification and combustion conditions. The major particulate control device issues to be addressed include the integration of the particulate control devices into coal utilization systems, on-line cleaning techniques, chemical and thermal degradation of components, fatigue or structural failures, blinding, collection efficiency as a function of particle size, and scale-up of particulate control systems to commercial size.

The conceptual design of the facility was extended to include a within scope, phased expansion of the existing Hot Gas Cleanup Test Facility Cooperative Agreement to also address systems integration issues of hot particulate removal in advanced coal-based power generation systems. This expansion included the consideration of the following modules at the test facility in addition to the original Transport Reactor gas source and Hot Gas Cleanup Units:

1. Carbonizer/Pressurized Circulating Fluidized Bed Gas Source.

2. Hot Gas Cleanup Units to mate to all gas streams.

3. Combustion Gas Turbine.

4. Fuel Cell and associated gas treatment.

This expansion to the Hot Gas Cleanup Test Facility is herein referred to as the Power Systems Development Facility (PSDF).

The major emphasis during this reporting period was continuing the detailed design of the facility and integrating the particulate control devices (PCDs) into structural and process designs. Substantial progress in underground construction activities was achieved during the quarter. Delivery and construction of coal handling and process structural steel began during the quarter. MWK equipment at the grade level and the first tier are being set in the structure. 
The detailed design of the PSDF continued with refinements to P\&IDs, preparation of specification bid packages and a move towards freezing the design. The integration of PCDs and the sampling system in the MWK and FW portions of the process structure continued and detailed civil, electrical, instrumentation and controls, and mechanical design information were exchanged between the design teams. SRI continued with simplifying the design and casting of the particulate sampling system cyclone manifold for the PSDF, working with the engineering design teams to resolve interferences and preparing to issue drawings for construction. The skid mounts for the insertion sampling probes are being fabricated and assembled.

Construction is progressing well at the site. Most of the construction activities at the beginning of the the quarter concentrated on completing most of the underground pipe trenches and electrical ducts. The MWK and FW motor control center (MCC) buildings are being erected. Final bolt-up on the coal handling structural steel has begun and the process structural steel erection is in progress. The installation of underground piping and associated fire hydrants and diesel pumps is being completed. The construction of the administrative building has begun and the building shell was completed during December. SCS began putting together a complete package of bulk materials (pipe, fittings, valves and other mechanical components) in the MWK process for procurement.

The contract negotiations between FW and its topping combustor subcontractor concluded and the subcontract was signed. Terms were negotiated between FW and its gas turbine supplier, and a purchase order was issued. Design of all equipment in the FW train are progressing well. The action items from the Design and Operability Hazard Review (DHR) of the APFBC System are being reviewed.

The PCD equipment designs are progressing well. Purchase orders for equipment fabrication and procurement have been issued. MWK has completed their design and engineering and issued all drawings, databases and other material for construction. The operating and instruction manual is scheduled for completion in the next quarter. Many of the $39 \mathrm{MWK}$ train major components were delivered to the site, and procurement activity of the remaining items is progressing.

It should be noted that this report includes accounts of progress made by Foster Wheeler (FW), M. W. Kellogg (MWK), Combustion Power Company (CPC), Industrial Filter \& Pump (IF\&P), Westinghouse, Southern Research Institute (SRI), Nolan MultiMedia, and Southern Company Services (SCS). 


\subsection{REVIEW OF TECHNICAL PROGRESS}

\subsection{PROJECT MANAGEMENT}

SCS met with DOE and EPRI in early November to discuss project, cost and schedule status along with the proposed test plan for the MWK train. The budget and cash flow information along with design and construction schedules and cost management reports were discussed. SCS presented the construction progress and the proposed construction sequence of coal handling and process structural steel and setting of equipment. Since the meeting, the delivery of structural steel for the coal handling structure began on November 14, and the Steel City Erection Company began erection of steel. Process structural steel erection was started in December.

SCS requested revised budget and cash flow information from all subcontractors for inclusion in the Continuation Application for Budget Period 4 which will be submitted to DOE in January, 1995. The cost information will be based on an updated project schedule. In the new schedule, the mechanical completion of the MWK train will be achieved by October 1995, followed by shakedown and characterization tests. Except for the topping combustor and the gas turbine, mechanical completion of the FW train will be achieved by January 1996, and the mechanical completion of the entire train is projected for May 1996.

All MWK design and engineering related activities came to a close during this quarter with the issue of all remaining drawings for construction. FW and SCS held a Detailed Design Discussion meeting in Livingston on November 15-17, 1994. The review of drawings and other documentation was followed by discussions on the level of completeness and schedule of all design areas and its impact on construction progress, APFBC design hazard review report, and approval of variance notices and bid tabulations.

FWUSA and Westinghouse signed a subcontract agreement for the Topping Combustor. FWUSA issued a formal purchase order to Allison for the Gas Turbine Generator. Delays in concluding the agreements with Westinghouse and Allison has impacted receipt by FWUSA of design information necessary to complete engineering, and is impacting delivery of FW equipment to the field. 


\subsection{PHASE 1 - CONCEPTUAL DESIGN ACTIVITIES}

\subsubsection{Task 1.4 Transport Reactor Development Unit}

The final report describing all the TRDU test runs, including the results of data analysis is being prepared by EERC and is due by the end of February, 1995.

\subsection{PHASE 2 - DETAILED DESIGN ACTIVITIES}

\subsubsection{Task 2.1 Detailed Design}

\subsubsection{MWK: PSDF Transport Train}

The PSDF detailed design was essentially completed with the remaining design documents issued for construction (IFC). These documents included all remaining piping isometric drawings as well as instrumentation and electrical drawings. The material take-offs for piping, instrument, and electrical bulk items were completed. Most of the action items from the "outstanding issues review meeting" were resolved. Comments on the transport reactor combustion mode test plan were issued. Several documents were issued for construction: (1) instrument index, (2) final equipment data sheets, (3) control wiring diagrams and receptacle layouts, (4) bill of material for piping, (5) piping paint and insulation summaries, (6) plot plans, (7) all remaining piping isometrics, (8) pipe support drawings with quantities, (9) cable tray layout conduit drawings, and (10) instrument conduit drawings. The Production check estimate was completed in December. About $65 \%$ of the operating instruction manual was completed. The on-site storage of MWK equipment was inspected and a report on storage recommendations was issued.

A two-day constructability meeting was conducted in Houston to discuss construction sequencing and other construction issues associated with the MWK portion of the project.

\subsubsection{FW Team Activities}

The Phase II detailed engineering and Phase III procurement activities continued. A copy of the FW Detailed Project Schedule, dated 1/10/95, is included in Appendix A. The following activities occurred during the fourth quarter of 1994.

A kick-off meeting was held with Westinghouse at Foster Wheeler's offices on October 20, 1994, with representatives from DOE, Westinghouse, Foster Wheeler, and SCS to 
review the execution and deliverables of Westinghouse's scope of supply. Discussions included the results of the 18" MASB/Topping Combustor testing at UTSI, features/design planned for Wilsonville's Topping Combustor, Westinghouse's project execution plan and schedule, and operation and control.

Foster Wheeler and SCS met in Livingston, NJ on November 15-17, 1994 to discuss the status of detailed design, including review of drawings and other documentation to ensure SCS and FW are in agreement on what is to be delivered (content and schedule), level of completeness and schedule of each design task (by discipline), and how the schedule fits in with SCS design and/or construction requirements. In addition, a preliminary review of the design hazard review report was held. Also, a review of manhours expended versus budgeted, percent completion for each detail design area/activity, and remaining schedule for each design area, all by discipline, was conducted. The agenda from the meeting is included in Appendix B.

Allison's exceptions to FW job specification 4161-72A23 were reviewed, and resolution or action recommended for each exception. Ten optional items which Allison quoted for consideration were reviewed and finalized.

FW has opted to take full design responsibility for all piping from the alkali getters through the topping combustor and into the gas turbine. This decision was made due to Allison's reluctance to take responsibility for the spool piece, and the fact that FW is responsible for the design of everything else in the system, which must be modelled for pipe stress as a single system under one company's control. (See FW letter no. 2.1-665, dated 12/14/94, "Topping Combustor/Gas Turbine Piping System" in Appendix C)

FW completed a review of refractory lined pipe expansion joint design with respect to possible corrosion attack. (See attacted FW Letter No. 2.1-616, dated 10/21/94, "Expansion Joints in Lined Pipes" in Appendix D.) As a result, the construction material of all expansion joint bellows shall be Inconel $625 \mathrm{LCF}$, and all the bellows shall be two-ply testable with leak detector between plies. Also, the expansion joint design will employ impervious castable refractory for the internal insulation (to minimize the migration of corrosive gases to the bellows) and ceramic fiber blanket for the external insulation (to maintain bellows temperature between 400 and $800{ }^{\circ} \mathrm{F}$ to prevent any possible gas condensation in the event the gas finds its way to the bellows wall). In addition, thermocouples will be attached to each bellows in the oxidizing combustor train, to provide the actual bellows metal temperature to ensure gas condensation will not take place. FW's experience in the reducing environment service similar to the carbonizer train showed that condensation corrosion is not a problem with the material Inconel 625 for design life of 2000 hours, therefore thermocouples are not 
considered necessary for the carbonizer train when the design precautions stated above are implemented.

FW evaluated the transient behavior of the gas temperature at the inlet and outlet of the carbonizer PCD to establish a design basis for Oak Ridge National Laboratories to use as input for analysis of tubesheet stress in the IF\&P PCD, which they are performing under a DOE contract. The evaluation of PCD temperatures, issued via FW Letter No. 2.1-636, dated 11/11/94, "PCD Temperature" is included in Appendix E.

Electrical and instrumentation detail design, drafting of plant \& piping layouts, and updating of the P\&IDs continued. FW issued 120 volts user list, and defined the 4.16 $\mathrm{kV}$ conduit stub-up for the Booster Air Compressor. The gas turbine generator requisition was revised based on ongoing discussions between FW and Allison. FW reviewed SCS comments on elementary drawings. FW issued an updated Instrument Reference Schedule and requisition index, instrument installation details, the Emergency Trip System interlock logic and electrical ladder diagrams, and power and control wiring drawings.

FW issued an updated tabulation of APFBC sample point descriptions, including an extracted list of blinded sample nozzles. Piping isometrics were issued for lined piping LP0612, 0801, 0806, 0814, and 0913. FW reviewed temperature indicating paints for refractory lined items. Also, the effect of combustor vibration on equipment, steel and personnel was reviewed. FW issued updated loads for the combustor system equipment, updated drawings with loads from refractory lined piping, and an electronic copy of the latest PDS model. FW updated the interface lists with IF\&P, Westinghouse, and SRI.

Nozzle details were finalized for SRI sample connections, and the source of the liner supply for the SRI extraction probes was defined. FW also issued a Westinghouse PCD (FL0352) nozzle stress summary. FW defined field refractory work for the alkali getters, reviewed the location of lifting blocks on lined pipes, and defined the procedure for vendor testing of lined pipe. In addition, the material of construction for on/off ball valves was reviewed, and utility station hoses and hose couplings were designed.

\subsubsection{Balance-of-Plant Activities}

Significant progress on several on the balance-of-plant systems was made during the last quarter. A summary of the balance of plant design activities arranged by engineering disciplines follows. 


\section{BOP Engineering - Mechanical}

Nitrogen System: The nitrogen system evaluation continued as clarifications to the bids and options were addressed and resolved. During December the preferred vendor was identified and the evaluation focused on resolving the remaining scope of supply. A more definitive cost analysis of the bids was performed, and the cost analysis of the alternatives required a significant amount of time in comparing the break-even points on liquid delivery versus on-site generation and lease purchase. The award of the contract is expected in January 1995.

Ash Handling Systems/Dense Phase Conveying Systems: Engineering continued its design layout of the ash handling systems. The detail design of the ash handling system, along with the other pneumatic conveying systems (ground coal and limestone, coke, LASH and other feed materials), will be performed by contractors based on specifications developed by SCS. A portion of the work being performed for the package is the preparation of drawings identifying the pickup points. These specifications continue to be prepared and are scheduled for release in January 1995.

Fire Protection: The installation of the underground fire protection piping and hydrostatic test of the system was completed. The design of the fire protection pump house was completed and sent to the job site. The remaining design items are the riser systems within the process structure. The designs are scheduled to be performed once FW and MWK have completed their designs within the process structure near the end of the first quarter of 1995.

Miscellaneous Utilities: The off-site utilities of potable water and demineralized water from Alabama Power Company have been discussed and agreed upon. Design of the potable water system are nearing completion with the near issue of the potable water booster pump system. The sanitary sewer system design was released to the field in November and the bids for the sanitary lift stations were reviewed by design and a recommendation made in December.

Final Gas Cleanup: The bids for the stacks were received in late December. The draft of the baghouse specifications were circulated for internal comments. The bid package issue date is early January 1995. The draft specifications for the dilution air fan were developed during December with an expected bid package issue date of January 1995.

Coal and Limestone Systems: The bids for the mill systems continue to be reviewed. Questions have been submitted to the bidders on clarifications to the bids. The projected award date is February 1995. The bids for the coal/limestone conveyor 
system were evaluated and a recommendation was made in late December based on final clarifications being submitted by the recommended bidder. The projected award is January 1995.

Tanks, Hoppers and Silos: The design of the miscellaneous tanks, silos and hoppers continues. The design of the service water tank was completed in December 1994. The designs of the crushed coal and limestone silos is complete except for the interfaces to the mill systems.

Steam and Condensate Systems: The P\&ID's for the FW cooling water and the MWK steam/condensate system are nearing completion. The drafts of the pump and heat exchanger specification packages were completed in December and are being reviewed.

Cooling Water and Service Water Systems: Detail design of the cooling water system continued. The bid package for the cooling towers is progressing with an expected release in January 1995. The design of the raw water system continued during December, and the pump sizing calculations were completed. The design of the 400,000 gallon service water tank was completed. The draft routing of the raw water pipe from the adjacent E. C. Gaston plant river intake structure to the PSDF site was issued to Construction for their comments.

Auxiliary Fuel: The preparation of the propane system bid package was completed in December. The projected release to bid date is January 1995.

\section{BOP Engineering - Electrical}

During the quarter, a new lighting supplier was identified which will offer acceptable quality yard and roadway lighting fixtures at a significant savings. Equipment arrangement for the MCC - L/O buildings was completed. The $230 \mathrm{KV}$ line tap and switch structure locations were determined. A meeting and equipment survey was held with MWK representatives at the site to verify equipment storage/maintenance requirements. A number of vendor electrical documents were reviewed. Work was resumed on the essential power engine generator specification and inquiry. About 150 new raceways were designed and added to the cable routing database. Electrical equipment arrangement was revised throughout the facility based on design evolution. Load tabulation for the DC system began. 


\section{BOP Engineering - Civil}

The Process Structure base slab drawing was issued to the site. These drawings utilize expansion anchors to anchor most of the equipment. Large diameter anchor bolts and bolts for rotating equipment will be poured in place. In December, the process structure base slab drawings was revised to include additional equipment anchor bolts, and to indicate revisions made during the construction activities.

The main air compressor concrete foundation drawings were issued to the site. This foundation will be poured adjacent to the process structure base slab and will utilize the process structure drain system to collect any leakage from the compressor. The process structure drain system will be routed to an oil-water separator prior to discharge through the approved NPDES discharge.

SCS continued to review and check the structural steel shop drawings for the process structure. SCS has received the shop drawings for Sequences $2,3,4,6,7, \& 8$. The contract drawings are being revised for Sequences $5 \& 7$, and will be issued to the fabricator in January 1995. Marked prints have been issued to the fabricator for his use until all of the contract drawings have been updated.

SCS reviewed the structural computer model of the process structure for dynamic loads associated with the FW equipment. SCS identified a potential problem with the maximum anticipated amplitude associated with the dynamic loads supplied by FW. After several discussions with FW, it was decided to begin operation of the facility and monitor any vibrations in the structure. SCS noted that a spring system would be required to dampen the loads as originally proposed by $\mathrm{FW}$.

SCS is reviewing the need for hoists and monorails in the process structure. This will be an ongoing activity as the need for hoists are identified in the process structure. The guy wire analysis for the process structure will be completed in January 1995. Several loading conditions will be required to complete the analysis. This analysis is required since the delivery of FW equipment will not be compatible with the construction of the process structure. SCS is reviewing to see if the MWK portion of the process structure can be erected without the FW portion of the structure in place.

SCS developed a preliminary computer model of the ash handling structure. As the ash handling process is developed, the model will be completed and the design of the structural steel and column foundations will be started. Work continued on the overhead crane inquiry package for the process structure. The drawings and specification will be completed and issued for bids in January. The proposals for the 
Process Structure elevator were received in December. The review process has started and the contract will be awarded in January 1995.

\subsubsection{Process Hazard Review}

Foster Wheeler completed a review of suggestions for 50 percent of the P\&IDs covered in the August Design Hazard Review. The majority of the suggestions were accepted as valid and the proposed modifications are being incorporated into the design of the advanced PFBC facility. The two filter vendors, Westinghouse and IF\&P, agreed to the suggestions made in their Design Hazard Review and have incorporated them into the design of the filters.

In December, SCS completed a review of FW vendor P\&IDs not available in August. These included conveying air and booster compressors from Ingersoll Rand, four propane-fired air heaters from Process Combustion Corporation, and the fuel gas and vitiated air quench system from Johnson March Systems. The review of the Balance of Plant P\&IDs is scheduled for March 1995, but dates have not been set for the reviews of the P\&IDs for the Westinghouse topping combustor and the Allison gas turbine.

\subsubsection{Task 2.2 Facility Design Document}

The PSDF design documents are being updated and issued periodically with material received from all participants.

\subsubsection{Task 2.3 Environmental Permitting and Compliance}

Visits were made to the PSDF construction site for environmental reporting and inspection purposes. In accordance with the NPDES Stormwater Construction Permit for the PSDF, an annual report of site inspections and analytical data from site stormwater runoff was submitted to the Alabama Department of Environmental Management on October 25, 1994.

On October 5, a meeting was held with Woods Trucking Company to discuss ash transportation and handling options. Woods Trucking is a local company that specializes in transportation of both hazardous and non-hazardous waste. Due to new environmental regulations for landfills, the number of disposal facilities in Alabama has decreased from about 120 to 17 since the regulation came into effect. Approved subtitle $\mathrm{D}$ facilities serve regional districts in Alabama. The PSDF is in Shelby County which is in the service districts of two approved landfills. 
A significant part of this quarter was devoted to developing a wastewater treatment plan for the PSDF. Primarily, the wastewaters that are expected to be generated from the PSDF originate from the utility equipment (boilers and cooling tower) and possibly contaminated stormwater runoff. The pollutants that are usually associated with these types of wastewater are primarily $\mathrm{pH}$, total suspended solids, and possibly oil and grease. Thus, the strategy will be to design and operate a facility that will successfully manage these pollutants to the satisfaction of the NPDES permit requirements. Also, the use of the existing facilities at Wilsonville for treatment purposes is being taken into consideration. This consisted of a single, concrete yard drainage basin that was used to collect coal pile runoff from a previous Physical Coal Cleaning project at Wilsonville. For the study, potential wastewater streams and their expected characteristics and volumetric flows were identified. Based on this information, the existing structure at Wilsonville would need modification in order to treat the PSDF discharge streams.

\subsubsection{Task 2.4 Particle Characterization and Collection}

SRI's work this quarter focused on:

- Coordination with SiCAM and with Howmet on the casting of the cyclone manifold

- Coordination with Santek Engineering on control panel layout and wiring of the particulate sampling systems

- Coordination with SCS and with MWK on SRI's requirements for electrical cables

- Coordination with SCS on plans for testing particulate samplers in the SRI combustor

- Coordination with SCS on cost projections and the Continuation Application for Budget Period 4

- Final revision of P\&IDs and wiring diagrams

- Procurement of linear actuators, motion control systems, electrical enclosures, switches, indicator lights, control valves, fittings, transducers, control cabinets, and impactor parts

In November, SiCAM modifed the CAD model of the cyclone manifold so that the sizes of the interconnecting tubes would match the sizes of available ceramic rods to be used as cores in the wax patterns. SiCAM then made a plastic model based on the stereolithography file produced from the modified CAD model. In December, a rubber vacuum-cast mold was made from the plastic model. The mold will be used to produce 
the first wax pattern in January 1995. The first wax pattern will contain plastic rods inserted into the interconnecting tubes to show Howmet the proper location and orientation of the ceramic cores. After inspecting the first wax pattern, Howmet will make the ceramic cores and ship them to SiCAM. SiCAM will then produce four wax patterns containing the ceramic cores. The four patterns will be shipped to Howmet in January. In February, Howmet will use the wax patterns to prepare the ceramic molds that will be used to cast the manifold. Howmet expects to deliver the prototype manifold in March 1995.

In November and December, SRI prepared a layout drawing for the control panels on the particulate sampling systems. The control panel layout and the final version of the electrical wiring diagrams will be delivered to Santek Engineering in January. Santek will then be able to proceed with assembly of the sampling systems as soon as all of the parts are delivered.

On November 10, SRI met with MWK and SCS to discuss SRI's requirements for cables. During the meeting, SRI marked the locations of all SRI junction boxes on the MWK electrical layout drawings. After the meeting, SRI developed a detailed listing of all cables running from the I/O building to SRI's sampling and monitoring systems. The listing was sent to MWK and to SCS on November 16.

On October 13, SRI met with SCS to discuss arrangements for testing SRI's particulate and alkali samplers in the SRI pilot-scale coal combustor. The SCS personnel were given a tour of the coal combustion facility, and the group discussed various methods of evaluating the performance of the samplers. It was agreed that the new configuration of the five-stage cyclone assembly should be tested alongside the conventional five-stage cyclone train to ensure that the cyclone cutpoints are the same. The comparative tests of the two cyclone trains would be done ahead of the baghouse, where the flue gas temperature is typically about $300^{\circ} \mathrm{F}$. These tests would be followed by tests of the new cyclone configuration at higher temperatures to identify any problems with sealing or with materials of construction.

SRI's P\&IDs are now undergoing the final round of revisions before release of the construction issue, which is scheduled for January. The P\&IDs are being changed to better reflect the arrangement of the SRI systems in the FW train, to replace some rotameters with flow indicators, and to update instrument tag numbers. Draft versions of the SRI wiring diagrams have been completed for the inlet batch sampling system and for the sniffer system in the MWK train. Draft wiring diagrams for the systems to be installed in the FW train will be completed in January, and the wiring diagrams will be finalized as soon as terminal numbers are assigned by SCS. 


\subsubsection{Task 2.5 Particle Control Technologies}

The following presents a summary of progress made in the last quarter in the design, engineering and procurement of the Particulate Control Devices (PCDs) for the PSDF.

\section{Combustion Power Company PCD for the MWK Transport Gasifier}

Comments on revised P\&IDs and electrical diagrams were received from MWK and SCS in October, 1994. CPC has responded to some MWK comments. CPC's vendor engineering is in progress. Many details on the pressure vessels are being settled. CPC's vendor engineering on the refractory, baghouse, and recuperative/air-cooled heat exchanger should be nearly completed by the end of 1994. CPC's vendor engineering on the boost blower will be completed during January 1995. Work on routing of interconnecting piping for filter components has continued during the last quarter. Drawings received from MWK have defined the locations for interfaces for utilities.

\section{Industrial Filter \& Pump PCD for the FW Carbonizer}

IF\&P has established consulting relationships with a team from Mallett Technologies, Inc. Mallett Technologies will assist IF\&P in finalizing the flanged nozzle stress calculations for the external PCD design, as well as the finite element analyses and other related work directed to the ceramic tubesheet and other internal components of IF\&P's PCD. All of the external design and stress issues have been resolved and procurement of materials for fabrication has begun. Supported by efforts from Oak Ridge National Laboratory, Mallett Technologies will use data provide by Oak Ridge on the physical, material, and mechanical properties of the ceramic tubesheet and other ceramic components within IF\&P's PCD. This data will be used to help insure that the materials selected will be suitable for the process conditions and transients involved in the operation of the plant.

A materials evaluation program has been established with Martin Marietta Energy Systems in which samples of the IF\&P tubesheet will be sent to Oak Ridge for thermal and materials properties evaluations, including creep strength, modulus of rupture, modulus of elasticity, and coefficient of thermal expansion.

Members of the PSDF team visited IF\&P. The purpose of the visit was to review the IF\&P PCD internal design and provide comments on the detailed drawings. Other issues such as the delivery date of the PCD and procedures and recommendations for curing and shipping of the refractory lined vessel to Wilsonville were discussed. IF\&P 
has provided SCS with a Risk Quantification (Process Development Allowance) statement, assigning weighting factors and levels of development to the various PCD components and subsystems.

With regard to the internal design of the PCD, two outstanding issues remain, namely the use of a bellows versus a sliding seal for the inlet pipe design, and the support mechanism and sealing configuration of the tubesheet. IF\&P is closely focusing efforts on the critical sealing of the internal piping arrangement of the PCD with regard to the use of a bellows or other suitable expansion joint. Two suppliers have suggested the use of a bellows type seal in this area, although many bellows suppliers consider the high temperature and reducing atmosphere of this application to be problematic for bellows usage. A more promising approach involving the use of a sliding joint seal appears to be warranted, and two vendors have suggested this method in lieu of a bellows type seal.

\section{Westinghouse PCDs for the MWK Transport Gasifier and FW CPFBC}

Westinghouse is under contract to SCS to design and supply two PCDs to the PSDF at Wilsonville, Alabama. One PCD (FL0301) is to be located in the MWK transport reactor train. The second PCD (FL0352) is to filter gases from the combustor of the FW APFBC process. Contract start date for equipment delivery is October 1, 1993 and delivery of the PCD to the site was projected to be in the December 1994 - February 1995 time frame. The schedule has been adjusted by SCS to provide delivery of FL0301 by February 13, 1995 and FL0352 by June 3, 1995.

Detailed design of the two PCDs is complete. Some modifications to both sets of P\&IDs, created by review of the FL0352 drawings at FW and SCS, and also as a consequence of the Design Hazard Review at FW, are now being undertaken. A set of updated drawings has been issued for both PCDs.

During the Design Hazard Review for FL0352, Westinghouse was asked to review the materials design for the tanks and pulse pipes for low temperature operation created by gas expansion during the pulsing event. Westinghouse has analyzed the tanks and pulse pipes and has concluded that the stresses imposed on the pipe and tanks are well below allowable ASME code stress limits. Thermal analysis is ongoing to determine the steady state temperature distribution in the pipe walls assuming $10{ }^{\circ} \mathrm{F}$ ambient temperature. In the most extreme case, pulse pipe temperatures could reach below -20 ${ }^{\circ} \mathrm{F}$. Therefore, Westinghouse has concluded that the most cost-effective solution will be to heat and insulate the tanks to keep the gas temperature at around $100^{\circ} \mathrm{F}$. If that is done, the pulse pipe temperature will always be above $10^{\circ} \mathrm{F}$. Since SCS will be heat 
tracing other components in the plant, one option is that SCS will heat and insulate the two accumulator tanks on each of the two skids for FL0301 and FL0352. Westinghouse will supply the heat input and insulation requirements.

FW has provided Westinghouse with a new set of nozzle loads for FL0352. Westinghouse is repeating the ASME code calculations for the vessel to ensure that the design is adequate and to calculate the new resultant loads on the structure.

\subsubsection{Task 2.8 Experimental Test Plan}

Two draft test plan documents were issued for the MWK train, one dealing with operation as a combustor and the other with operation as a gasifier. MWK, Westinghouse, and Combustion Power Company responded with comments and were in general agreement with the proposals. A fruitful meeting between SCS and the DOE was held in Morgantown to discuss the test plans and vendor comments. The general appproach was endorsed, but a number of changes were recommended. These included an earlier start to gasification testing, an increase in combustion test hours, and closer alignment of PCD test conditions with operating conditions for CCT demonstration plants. The DOE agree to document some of their views to assist in the preparation of the next draft of the test plan.

\subsection{PHASE 3 - CONSTRUCTION, PROCUREMENT AND INSTALLATION}

\subsubsection{Task 3.1 Procurement}

\section{MWK Advanced Gasifier train}

Ten items were shipped to the site during the quarter: transport reactor (RX0201), heat transfer system (ME0540), the spent solids silo (SI0602), sulfator (SU0601), combustion heat exchanger (HX0203), conductivity analyzer (AE0402), spent solids screw cooler (FD0206), fines screw cooler (FD0502), sulfator solids screw cooler (FD0602), and feeder system air dryer (DY0210). The last remaining piece of the transport reactor and the filter section of the spent solids silo were also shipped. About fourteen pieces of equipment remain to be delivered which include two heat exchangers, the reactor primary cyclone and disengager, the solids handling equipment from Clyde Pneumatic (6 items), the analyzer shelter and instruments, the refractory lined slide valve, the shutdown relay system and the refractory lined pipe and transition pieces. 


\section{FW APFBC System}

Phase III procurement activities continued. FW issued instrument requisitions for vortexmeters, dial thermometers, pressure switches, knife gate valves, dP flow transmitters, rotameters, field mounted control switches, control valves, gage glasses, purge assemblies, thermocouples, orifice plates, and temperature transmitters. FW issued bid tabulations for Char Cooler (HX0255) and the emergency trip system. FW and SCS are reviewing the refractory lined pipe fabrication and delivery based on construction requirements to prioritize and expedite critical path pieces. The FW Component Schedule, dated 1/9/95, is included in Appendix F.

\section{Combustion Power Company}

Pressure vessels, internals, and refractory lined pipe were ordered in September, 1994 from Plant Maintenance Service Corporation (PMSC) in Memphis, TN. Expediting was considered, but costs were prohibitive. Completion of these items is expected in midJanuary, 1995. A trial fit-up of pressure vessel and piping components is scheduled for mid-January, 1995 at PMSC. Anchors for refractory installation will be installed by the refractory contractor, J.T. Thorpe, after preassembly in January, 1995. Support shelves for the refractory are being installed by the pressure vessel contractor. These activities will be followed by hydrotesting at PMSC.

After they have been hydrotested, items to be refractory lined will be shipped from PMSC at Memphis, TN to J.T. Thorpe in Houston, TX for refractory installation, thermal drying $\left(700-750^{\circ} \mathrm{F}\right)$ and painting. Refractory lined equipment will then be shipped to Wilsonville, AL for installation. CPC is expediting the two main pressure vessels and expect them to be shipped to Wilsonville in mid-March 1995. The remaining refractory installation will be complete in late April, 1995.

The recuperative and gas/air heat exchanger were ordered as a unit in September, 1994 from Phoenix Metallurgical in Houston, TX. Preliminary drawings were received in mid-November, 1994. There are a number of design details that have not been defined, primarily those dealing with thermal expansion. Expected delivery date is March, 1995.

The baghouse has been ordered from Aeropulse Corporation in Pennsylvania. A sketch was submitted to the supplier showing critical dimensions. Confirmation was given on the support pad location and the hold down bolt information requested by SCS. A vendor drawing was received in early December, 1994. 
Programmable logic controller components were ordered for delivery in early November, 1994. The boost blower was ordered in December, 1994 from Susquehanna Valley Systems, Inc. in Berwick, PA. No drawing submittals were expected this quarter.

\section{Industrial Filter and Pump}

With the IF\&P PCD external design nearly complete, SCS has extended authorization to begin procurement of the necessary components pending a final review of the Bills of Materials of the external components. Fabrication of the PCD vessel commenced in December, 1994 and the unlined pressure vessel is expected to be completed in March 1995.

\section{Westinghouse Filters}

The fabrication of the system for FL0301 is proceeding. The vessel has been fabricated and will be hydrotested in January. The fabricator for the tubesheet and the clusters has been selected and purchase orders for the tubesheet and cluster material have been placed. Fabrication is in progress and is on schedule. The purchase order for the FL0301-ME01 skid has been placed. The small skid FL0301-ME02 will be fabricated at Westinghouse Science and Technology Center. Fabrication is on schedule. Quotes on internal back pulse pipes and nozzle covers have been obtained and purchase orders are being placed.

A fabricator for the vessel FL0352 has been selected and a purchase order has been issued. Detailed code design is on-going and is presenting Westinghouse with some problems that are being resolved. The dome height will increase by 15 inches but no interface points will be affected. With a redesign of the dome insulation, the weight of the vessel and dome will not increase beyond the 101.5 Ton estimate provided on September 6, 1994. However, reaction loads on the structure will change due to the new nozzle loads. Westinghouse does not anticipate any change in the June 30, 1995 delivery date.

The anchor bolts for FL0352 are 1-3/8 inches in diameter. The purchase order for fabrication of the tubesheet and clusters has been placed and the fabrication is proceeding on schedule. Fabrication for the back pulse skid (FL0352-ME01) and instrument skid (FL0352-ME02) is also proceeding on schedule. 


\section{SRI Particulate Sampling}

During the past quarter, SRI made considerable progress on the procurement of sampling system components. Bids were received for the linear actuators, motion control systems, electrical enclosures, switches, indicator lights, control valves, fittings, transducers, control cabinets, and impactor parts. The procurement packages for these items were reviewed and approved by SCS, and purchase orders were issued. Table 1 gives a summary of the orders placed thus far. All remaining components of the sampling systems will be ordered in January. The remaining components include the impactor stages, the ceramic liners for the bauxite cartridges, regulators, electric heaters, and computers.

Table 1. Purchase Orders Issued to Date by SRI

\begin{tabular}{|l|l|l|}
\hline Item & Supplier & Date \\
\hline \hline Probe insertion mechanisms & Santek & $07 / 28 / 94$ \\
\hline Port sleeves & Santek & $09 / 19 / 94$ \\
\hline Steady rest parts & Santek & $09 / 19 / 94$ \\
\hline Structure and sleeve changes & Santek & $10 / 25 / 94$ \\
\hline Ball valves & Marpac & $09 / 29 / 94$ \\
\hline Limit switches & Marpac & $11 / 10 / 94$ \\
\hline Probe assemblies & Alloy Engg. & $10 / 04 / 94$ \\
\hline Cyclone manifold model & SiCAM & $10 / 07 / 94$ \\
\hline Cyclone manifold prototype & Howmet & $10 / 11 / 94$ \\
\hline Cyclones & Alloy Engg. & $10 / 13 / 94$ \\
\hline Cyclone nozzle and caps & Allog Engg. & $10 / 25 / 94$ \\
\hline Control systems & Regan Controls & $11 / 02 / 94$ \\
\hline Linear actuators & Thomson & $11 / 08 / 94$ \\
\hline Enclosures, switches, lights & Southern Electric & $11 / 09 / 94$ \\
\hline Terminal blocks, clamps & Southern Electric & $11 / 09 / 94$ \\
\hline Manifold wax patterns & SiCAM & $11 / 17 / 94$ \\
\hline Control valves and fittings & Control \& Power & $12 / 05 / 94$ \\
\hline Transducers & Rosemount & $12 / 13 / 94$ \\
\hline Control cabinets & Optima & $12 / 14 / 94$ \\
\hline Relays for DCS interface & Ack & $12 / 27 / 94$ \\
\hline Impactor parts & Alloy Engineering & $01 / 06 / 95$ \\
\hline
\end{tabular}




\subsubsection{Task 3.3 Construction and Installation}

\section{Construction - Civil}

Many support activities for electrical and mechanical underground installations continued during the last quarter. The establishment of storage/laydown areas was completed. The foundations for the MWK and FW MCC buildings were poured and the erection of the building structure is in progress. All process structure concrete was completed with the exception of the equipment pads. The structural steel for the pipe trench access platform was set. Several MWK equipment arrived at the site. These were unloaded and prepared for storage.

Steel City completed the setting of the structural steel in the coal building and began final bolt-up. Steel City set sequence 2 Bay 2-3/B-C structural steel in process structure and continued modularizing other sequence 2 bends in laydown area.

\section{Construction - Electrical}

The main focus of electrical work for the quarter was underground duct runs and temporary power for the site. During the quarter, approximately 20,000 feet of four inch diameter conduit was installed. Duct runs completed in the quarter are as follows:

1. Pull Box \#1 to MWK Analyzer Building.

2. Pull Box \#1 to FW Analyzer Building.

3. Pull Box \#1 to Electrical Building started.

4. Pull Box \#2 to Pull Box \#3.

5. Pull Box \#2 to Propane Vaporizer Slab.

6. Pull Box \#2 to equipment slab west of pipe trench.

7. Pull Box \#4 to FW Analyzer Building.

8. Pull Box \#4 to Coal handling Structure.

9. Pull Box \#4 to Pull Box \#9.

10. Pull Box \#4 to Administration Building started.

11. Pull Box \#4 to Combustion Turbine started.

12. Pull Box \#5 to Combustion Turbine started.

13. Pull Box \#7 to Pull Box \#10.

14. Pull Box \#9 to Pull Box \#10.

15. Pull Box \#10 to Pull Box \#11.

16. Pull Box \#11 to Pull Box \#12.

17. Pull Box \#12 to Pull Box \#13.

18. Pull Box \#13 to Old Administration Building. 
19. Conduit stub-outs for process structure air compressors.

20. Conduit stub-outs for yard drainage/oil separator structure.

21. Conduit stub-outs for diesel fuel storage tank structure.

22. Various conduit stub-outs for site lighting structures.

23. Roadway lighting west side of site.

24. Yard lighting south side of site east to substation

Duct runs started in December but not completed include various yard lighting stub-outs around the process structure, equipment storage area, and coal/limestone area. The temporary power board for the process structure was completed and will be energized during the first week of January. The motor space heaters on equipment stored in the lay-down yard were energized. Also, some site ground rods were driven to verify proper drive depth requirements, and the problems encountered are being analyzed.

\section{Construction - Mechanical}

Fire Protection Pump House: Installation of the fire hydrants and post indicators was completed. The two existing diesel pumps were moved, set and shimmed to proper elevation on the pump house foundation. The underground piping was completed and tested. The jockey pump has been placed and piping to and from is being installed. Two pipefitters continue to work installing the fire pump suction and discharge piping at the pump house.

Potable, Raw and Demineralized Water System: The on-site installation of underground pipe for these systems continued. The route to Plant Gaston for the raw and demineralized water was determined. Materials for these lines was ordered and a contractor selected to bore under the roadways and railways. Material will be delivered and the boring contractor will begin work in January. Installation of the raw water line will begin in January. Approval from the railroad company is being sought before boring beneath railway lines can proceed.

Sewage Disposal System: Work continued on on-site installation of underground sewage disposal lines. In January the work will progress on off-site installation and should complete installation of the 2" HDPE lines to the sewage treatment plant east of the old administration building.

Bulk Material Order for MWK Process: SCS construction began working with MWK on putting together a complete package of pipe, fittings, valves and other components for procurement. Pipe sizes $3 "$ and over will be fabricated and procured from a fabrication shop. Pipe under 3 " size will be procured from a piping vendor and 
fabricated in the field. This decision was made after meetings with MWK revealed that their design supported procurement in this manner. The bid packages will be issued in January.

Warehouse/Maintenance and Administration Buildings: Sunbelt Builders is essentially complete with the warehouse facility. Final acceptance is pending a facility walkdown which will occur on January 12 between Sunbelt and Southern Company Services. Sunbelt Builders erected the administration building steel frame, installed the outside shell walls and continued with work on the building. The building shell was completed during December and HVAC and electrical work began. These activities along with architectural work will continue during the next quarter.

\subsubsection{Task 3.6 Preparations for Operations}

\section{Wilsonville Interactive Learning System (WILS)}

The WILS project is an extremely innovative interactive multimedia application for documenting the experience and knowledge gained at the PSDF through a vast storehouse of well organized visual, audio, and text-based information. When completed, WILS will contain a series of Technology Transfer Modules to provide highly usable, visually-based information on each technology at the Wilsonville facility. WILS will also contain a series of Interactive Video Training (IVT) modules on a variety of tasks. The Tech Transfer and Training modules are being developed concurrently with construction of the facility using 2D and 3D graphics and animation. Training modules will be completed prior to commissioning of each train to allow time for operator training; they will be revised and augmented with video following the shakedown period.

The third and final component of WILS is a multimedia archive designed to document operational experiences and equipment modifications that may occur at the PSDF, primarily through text, still photographs, live-action video, graphics and audio. WILS is being developed for delivery via a series of Windows-based interactive CD ROMs.

Significant progress on the WILS project was made this quarter in a number of areas:

- the review and revisions to the Real-time Monitors \& Sampling (RM\&S) module,

- the launching of the Advanced Gasifier/Transport Reactor train module (dubbed "K-train" for purposes of the WILS project), and

- script review by SCS of the HGCU modules and subsequent script revisions. 
During October, SCS visited Nolan's facility and reviewed the RM\&S module and WILS Introduction. A number of suggestions were made and a subsequent list of revisions was prepared and executed. The revised RM\&S module (not including the P\&IDs) was then submitted on a Syquest cartridge for review by SCS and SRI. Further discussions with SCS and SRI resulted in some changes in audio, a few text changes, and a number of graphics changes. Narration was re-recorded and replaced in the program. The most time-consuming change to make was the addition of cyclones to the empty manifolds on the probe device, which appears throughout the module in various configurations. Most of the changes were completed by the end of December.

Also during this period, graphics production on the K-train (MWK train) Technology Transfer module got underway. To facilitate development of the K-train, detailed storyboards were prepared, using 3 boxes of MWK vendor-supplied materials (largely P\&IDs) received from SCS. A total of 55 P\&IDs and other drawings were selected from these materials for use in the IVT programs.

Colorization of process gas and solids streams was addressed during the K-train kick-off meeting and later during the development of the storyboards. A list of 14 colors was chosen to designate different process gases, liquids and solids. A rainbow-colored key will be created and reside in the icon bar whenever a process flow diagram is shown. Clicking this key will display a color legend in a small vertical field that can remain open, be dragged by the user to any part of the screen, or be closed.

Based on K-train storyboards, new flowcharts were prepared (see Appendix G). These flowcharts represent the initial development of the K-train module. It shows the current branch points for P\&IDs, process performance tables, and chemical reactions. Safety related items will be covered in the training module. Additional branching will be added later to incorporate stills of major components. By mid-December, SCS completed revisions to the Integraph files for the MWK sections, and Nolan was given the go-ahead to proceed with plans for converting the appropriate images for use in the WILS project. Individual PICT files for the fly-around animation and the "You Are Here" locator feature will be created.

Scripts for two of the four PCD modules in the HGCU section (on K-train PCDs) were revised based on a review by SCS. Script revisions for the remaining two modules (on A-train PCDs) will take place in January. Storyboards for all four HGCU modules will then be prepared.

Production of training modules for the K-train can get started once MWK and SCS has completed the operations manuals for the MWK train. The current projected start date 
is soon after completion of the manuals in May 1995. Completion of the initial training modules for the K-train is projected to be July 1995 to allow time for operations personnel to absorb training materials prior to commissioning the Transport Reactor train. This is a very tight time frame for producing multimedia training. 


\subsection{PLANS FOR FUTURE WORK}

1. Complete work on the TRDU final report and orderly closure of the contract with UND/EERC.

2. Work on the MWK operating and instruction manual was interrupted in December with the unfortunately sudden illness and death of Jim Patey. This activity, which is about $65 \%$ complete, will resume in January and completion is delayed. The final report on the MWK train design hazard review is to be issued.

3. For the next reporting period, FW will continue detail design of electrical and instrumentation. SCS and FW should complete review of the APFBC Design Hazard Review findings, determine recommended action for each of the findings, and incorporate applicable comments in the APFBC P\&IDs and detail design. Other ongoing activities include finalization of the P\&IDs and logic diagrams/descriptions, and drafting of plant \& piping layouts.

4. SCS will continue with construction activities at the site. The MCC buildings, the coal storage foundation, most of the coal structure, and most of sequence 2 steel should be nearly completed. Process equipment will be set in place as needed to accommodate structural steel erection. The sequence 3 structural steel is being scheduled to be received during the next quarter. Relocation of the fire protection tank should occur in late January. Electrical will continue on the yard lighting, temporary power for the process structure, and duct runs into the Administration building for temporary power and telephone service. Mechanical will work on the fire protection pump house and process water lines and demineralized water from the E. C. Gaston steam plant pending railroad approval for boring under the railroad.

5. SCS engineering will continue to work on the balance-of-plant design and specifications. Technical evaluation of the nitrogen system will be completed. Bids and performance tests of the coal/limestone grinding mills will be evaluated. Also, the coal/limestone conveyor system vendor will be selected. Bids for the MWK and FW stacks will be evaluated. The ash handling/dense phase transport design will be performed by vendors based on specifications developed by SCS. Potable water and fire protection design will be completed except for the riser systems in the process structure. Design of miscellaneous tanks, silos and hoppers will continue. The configuration and building of display screens of the MWK 
portion of the DCS will be started. The specification for the emergency power generator will be completed and issued for inquiry. Raceway and cable routing design will continue. SCS will continue to check structural steel shop drawings for the process structure and evaluate whether guy wires will be needed since the FW portion of the structure will not be erected simultaneously.

6. During the next quarter, $\mathrm{CPC}$ will continue fabricating major equipment in its system. The Granular Bed Filter vessel is being expedited to allow it to be assembled into the structure concurrently with steel erection. CPC data acquisiton system tests and instrumentation requirements such as nuclear level detectors will be resolved over the next quarter. IF\&P will also continue with the fabrication process. The detailed internal design of the IF\&P PCD will be finalized. Material characteristics data for the ceramic tubesheet will become available over the next quarter and will allow finalization of the tubesheet design. Refractory pouring, refractory curing, procedures for transporting the finished vessel and shakedown activity requirements will be defined. Westinghouse will complete the fabrication of the FL0301 vessel and will continue the fabrication of the FL0352 system. The nuclear level detector requirements and recommendations on both vessels will be specified by Westinghouse. The fabrication of the backpulse skids and instrumentation skids will continue.

7. In the coming quarter, the SRI control panel layout and wiring diagrams will be delivered to Santek, and Santek will begin the assembly of the sampling systems. All of the required components should be delivered by February. Programming of the control systems will begin in February, and the sampling systems should be completely assembled and ready for testing by the end of March. The only major remaining design-related tasks are the final revision of the P\&IDs and wiring diagrams, which should be completed next quarter. SRI will then release the construction issue of SRI's P\&IDs and wiring diagrams, provided that terminal number assignments are available. The sampling cyclones and prototype cyclone manifold will be received in March and tested in the SRI wind tunnel and in the SRI combustor in April.

8. SCS will continue preparation of an integrated test plan for the Advanced Gasifier train components and system for shakedown, characterization and normal operations. The development of operation precedures for the MWK train will be started upon completion of operation and maintenance instructions manual that is being written by MWK. 
APPENDIX A

FW DETAILED PROJECT SCHEDULE 


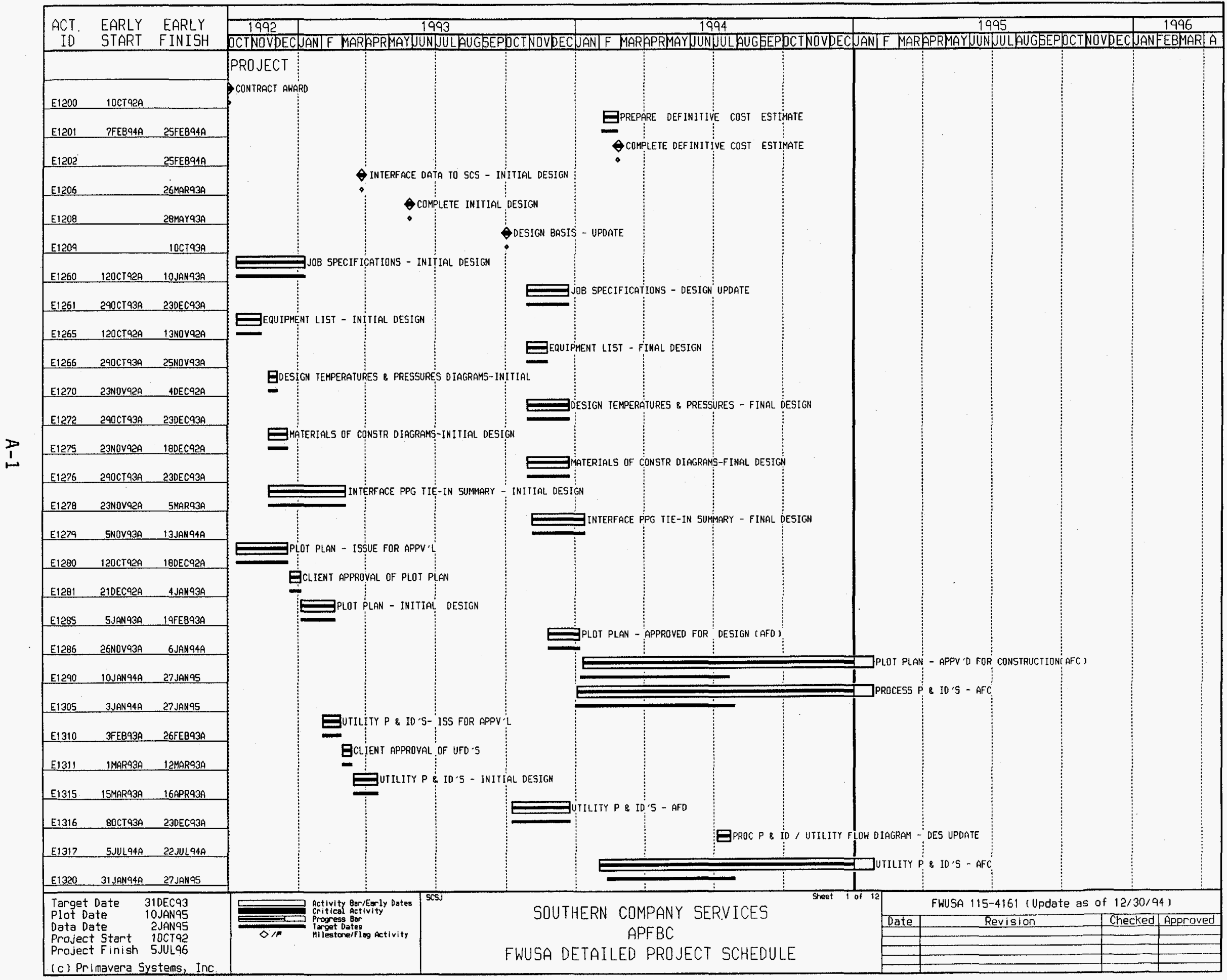




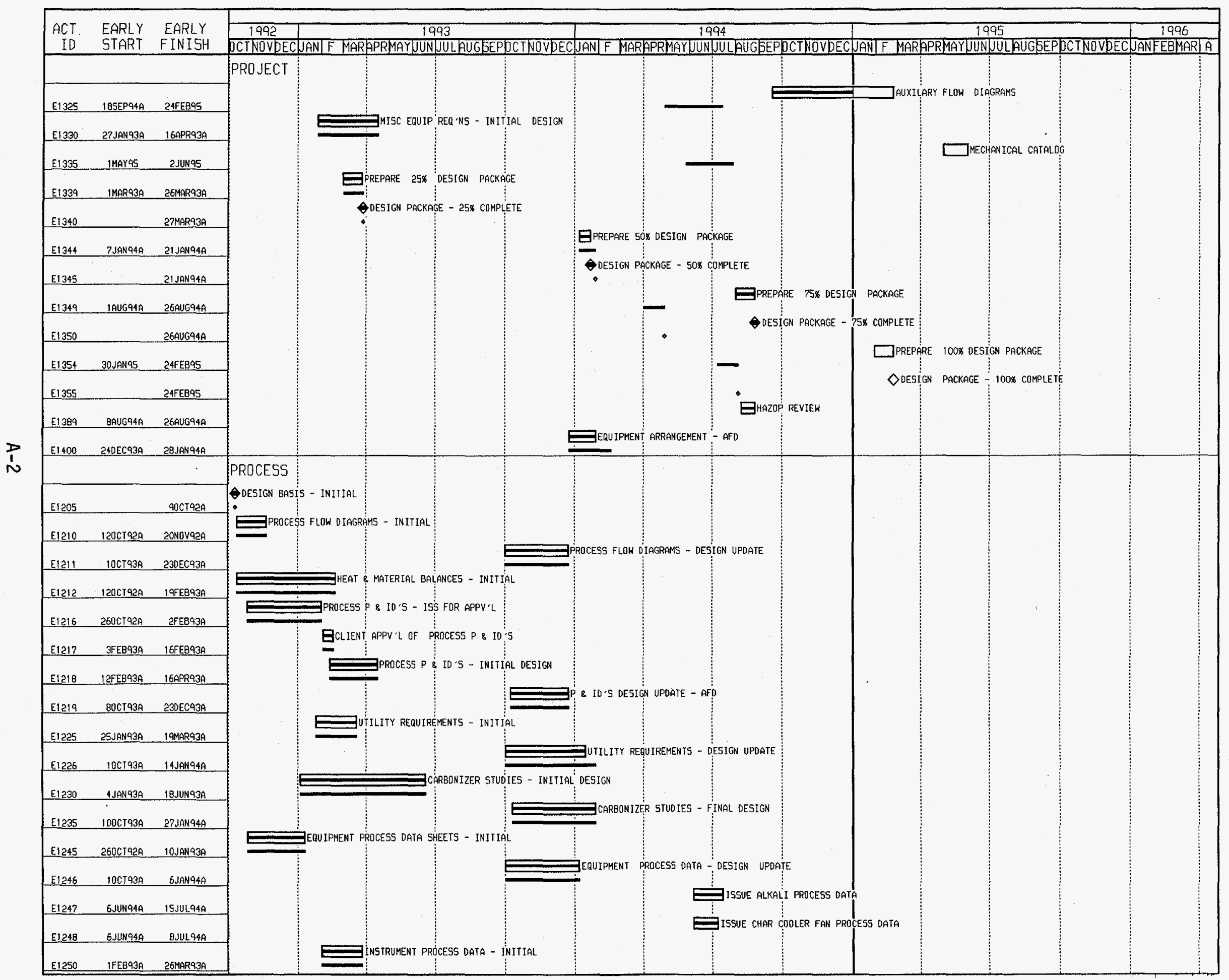




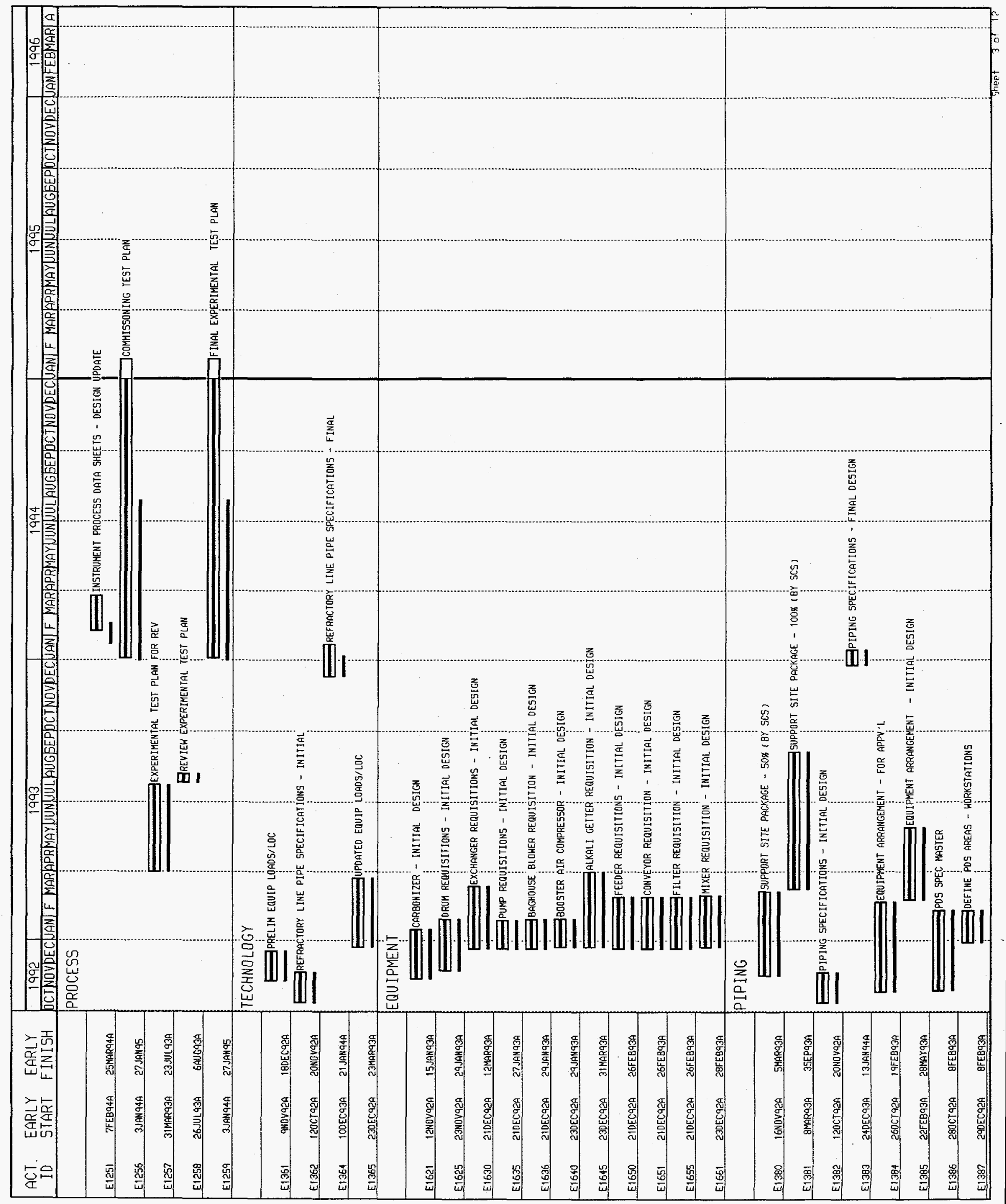

$$
\text { A-3 }
$$




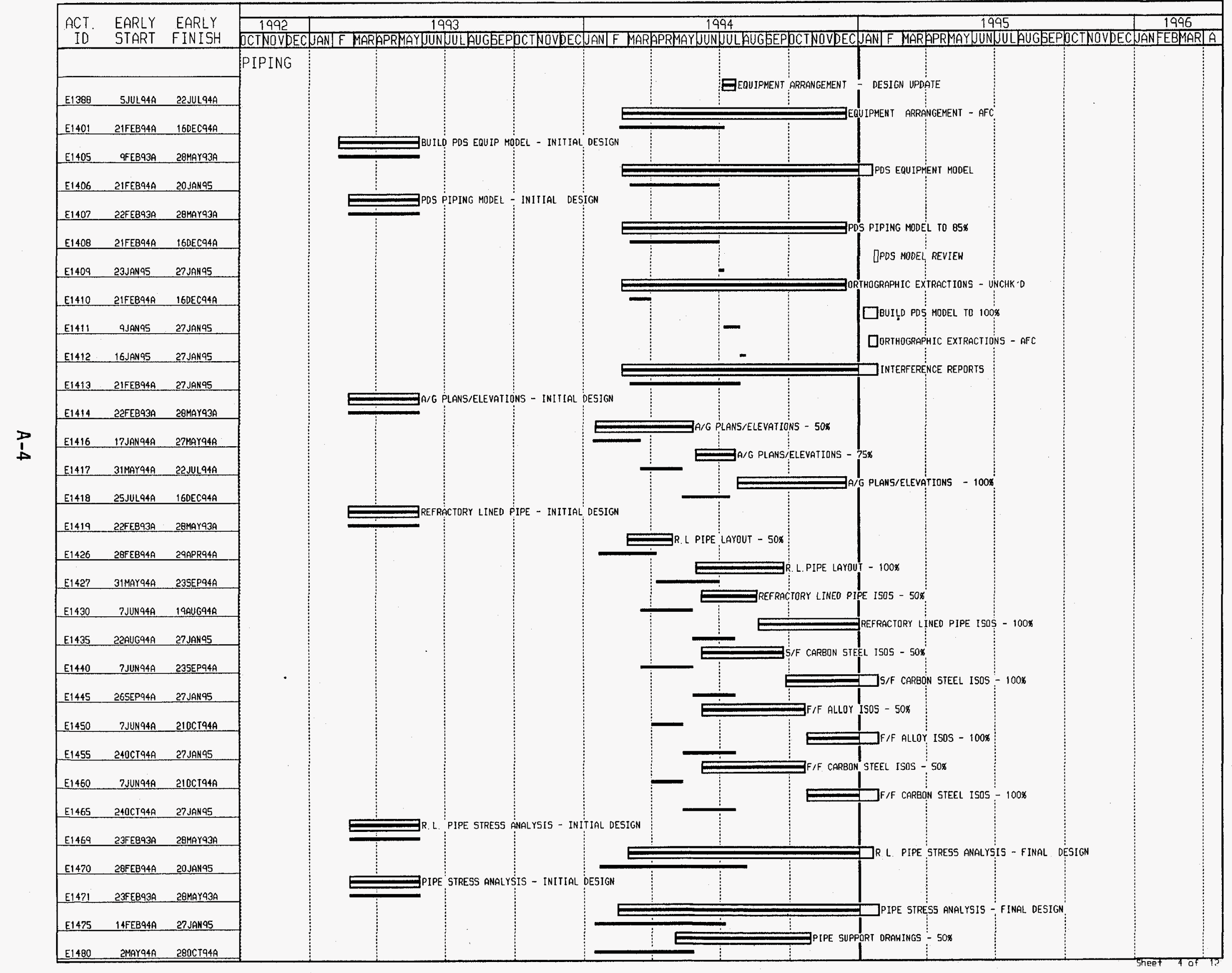




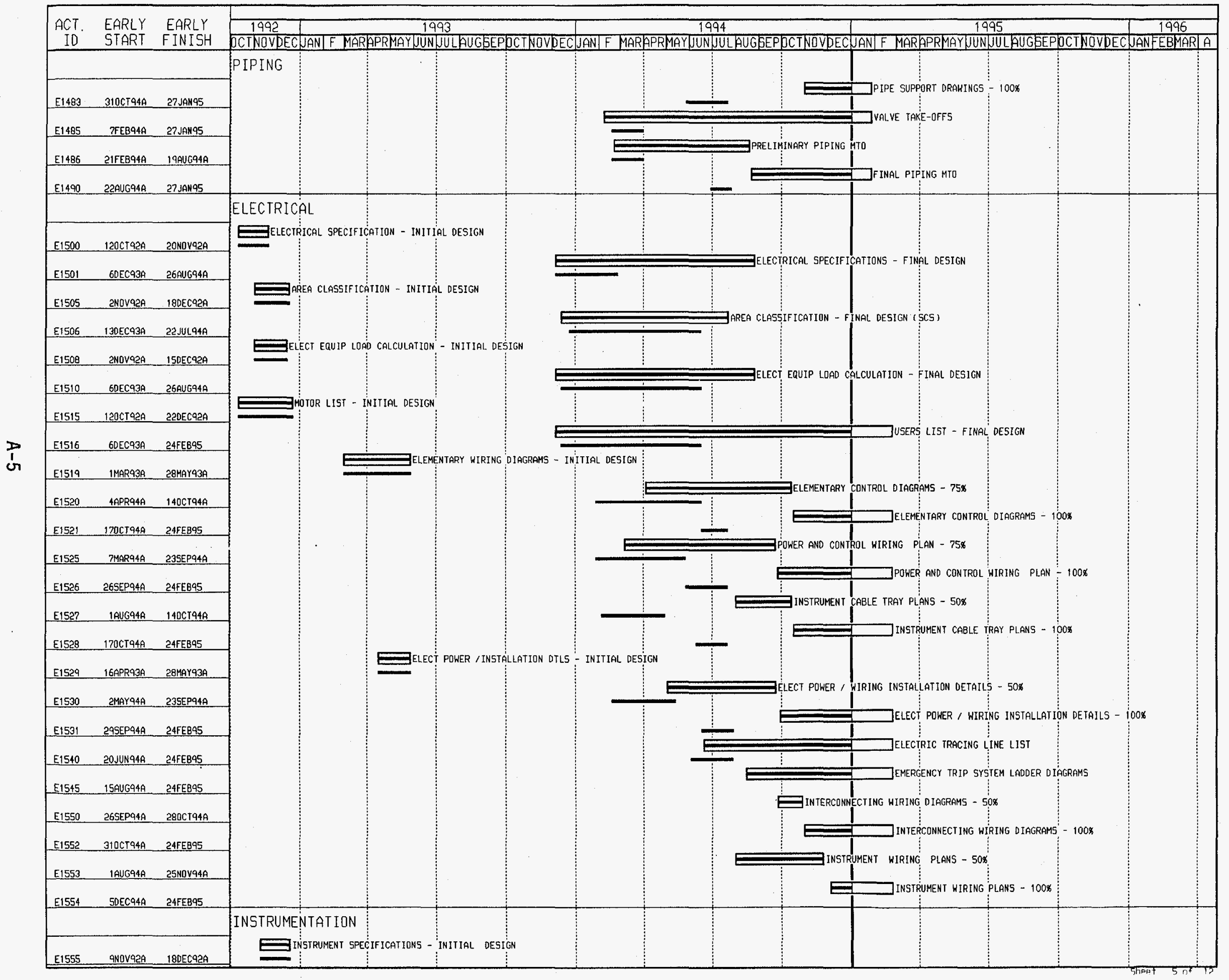




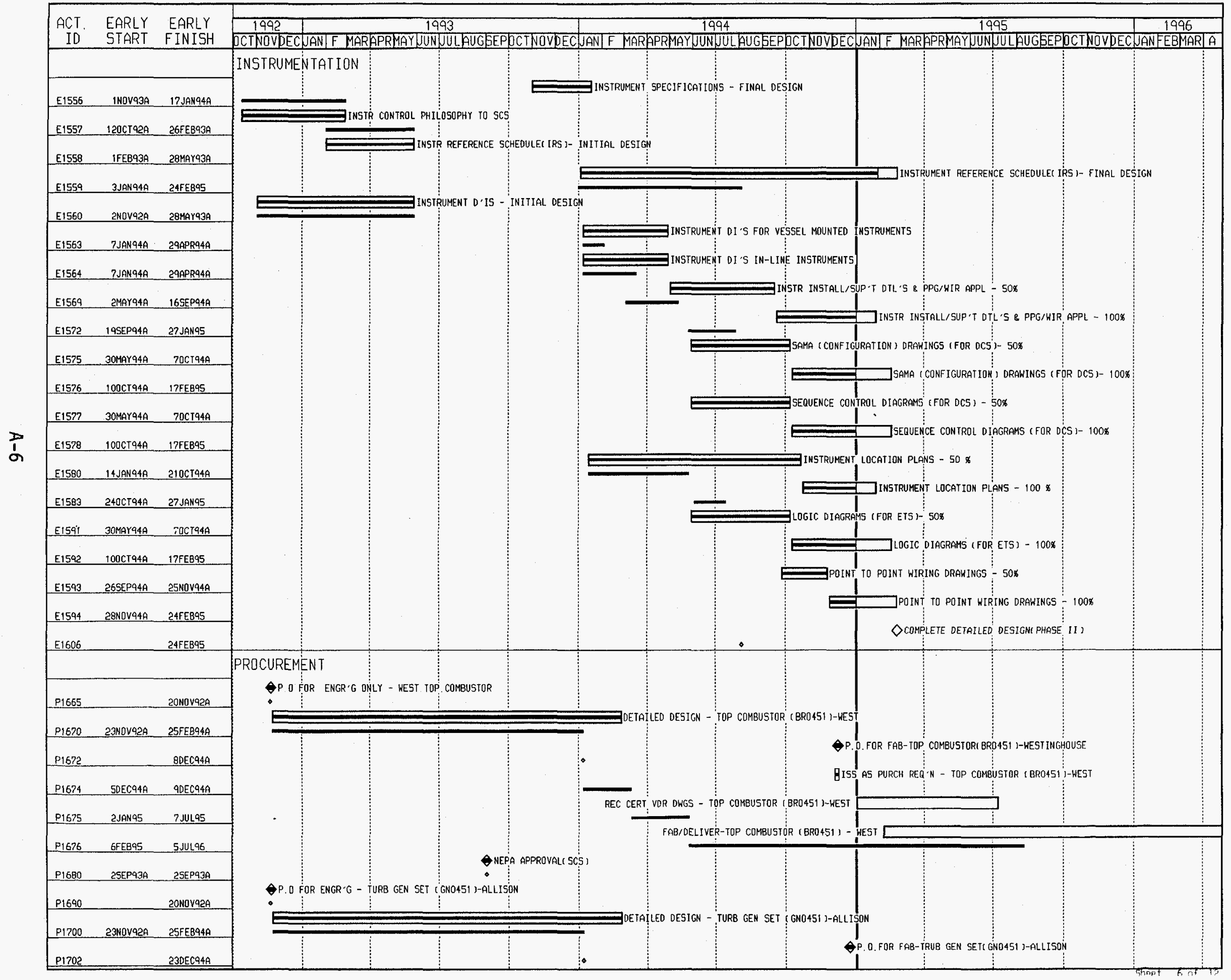




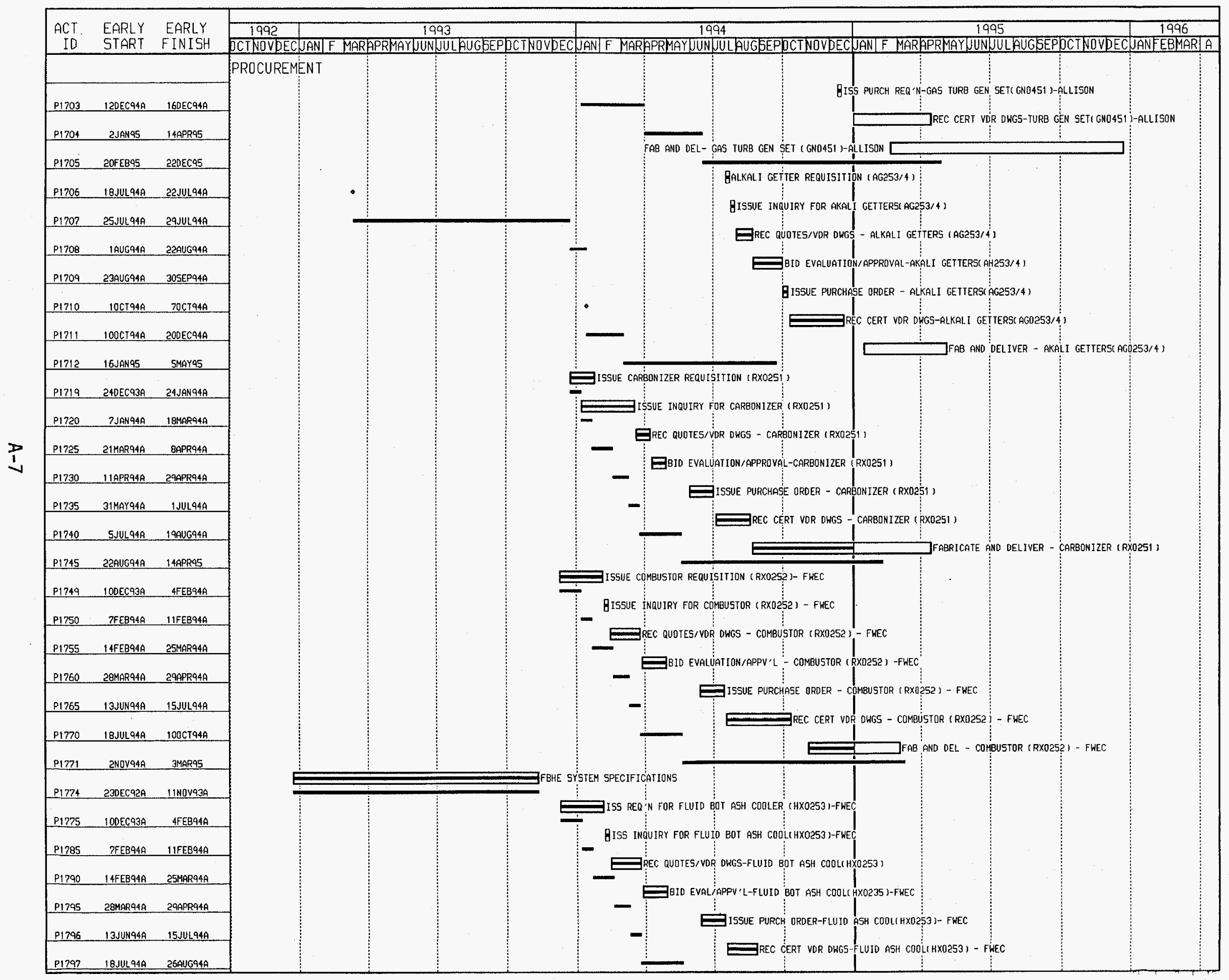




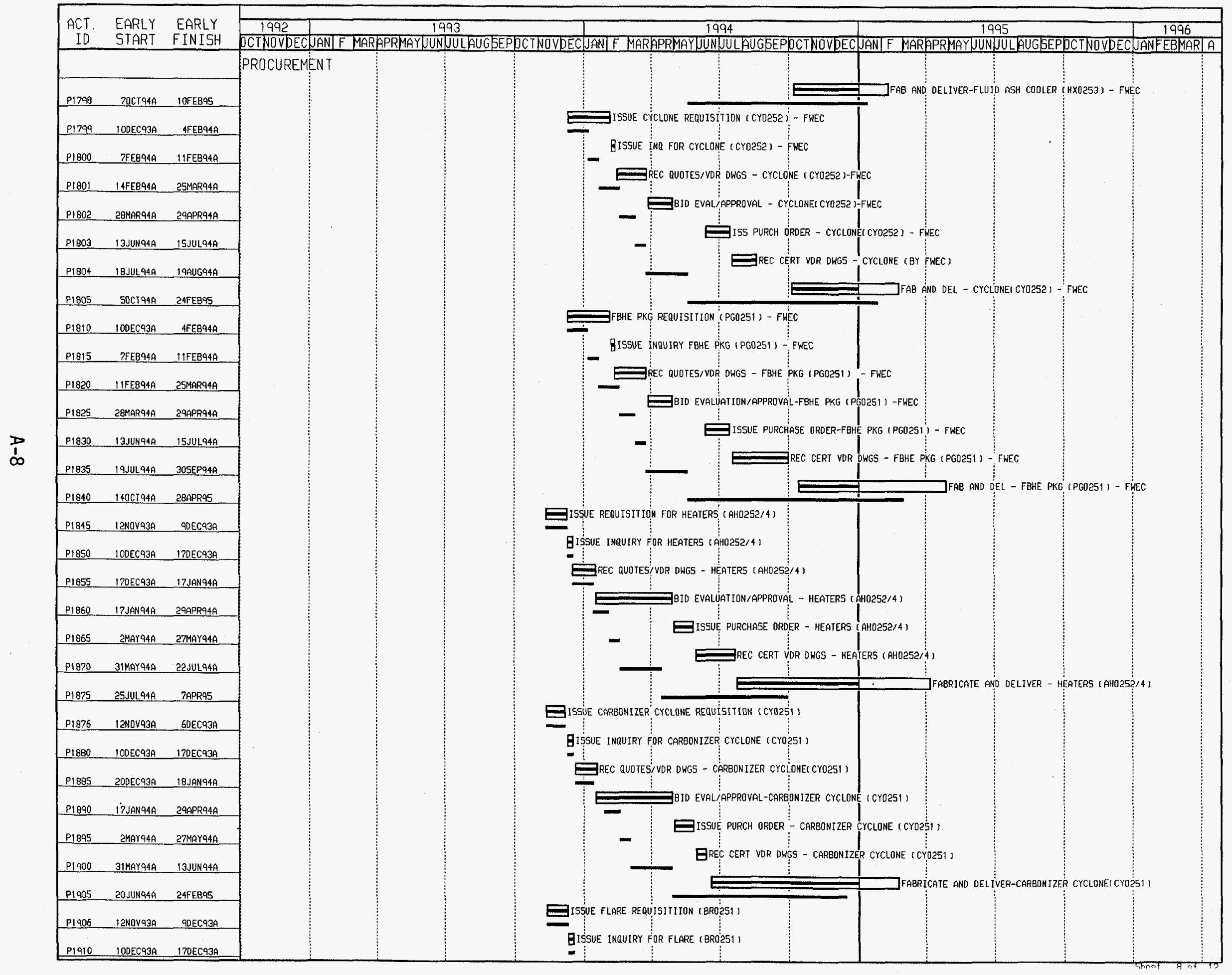




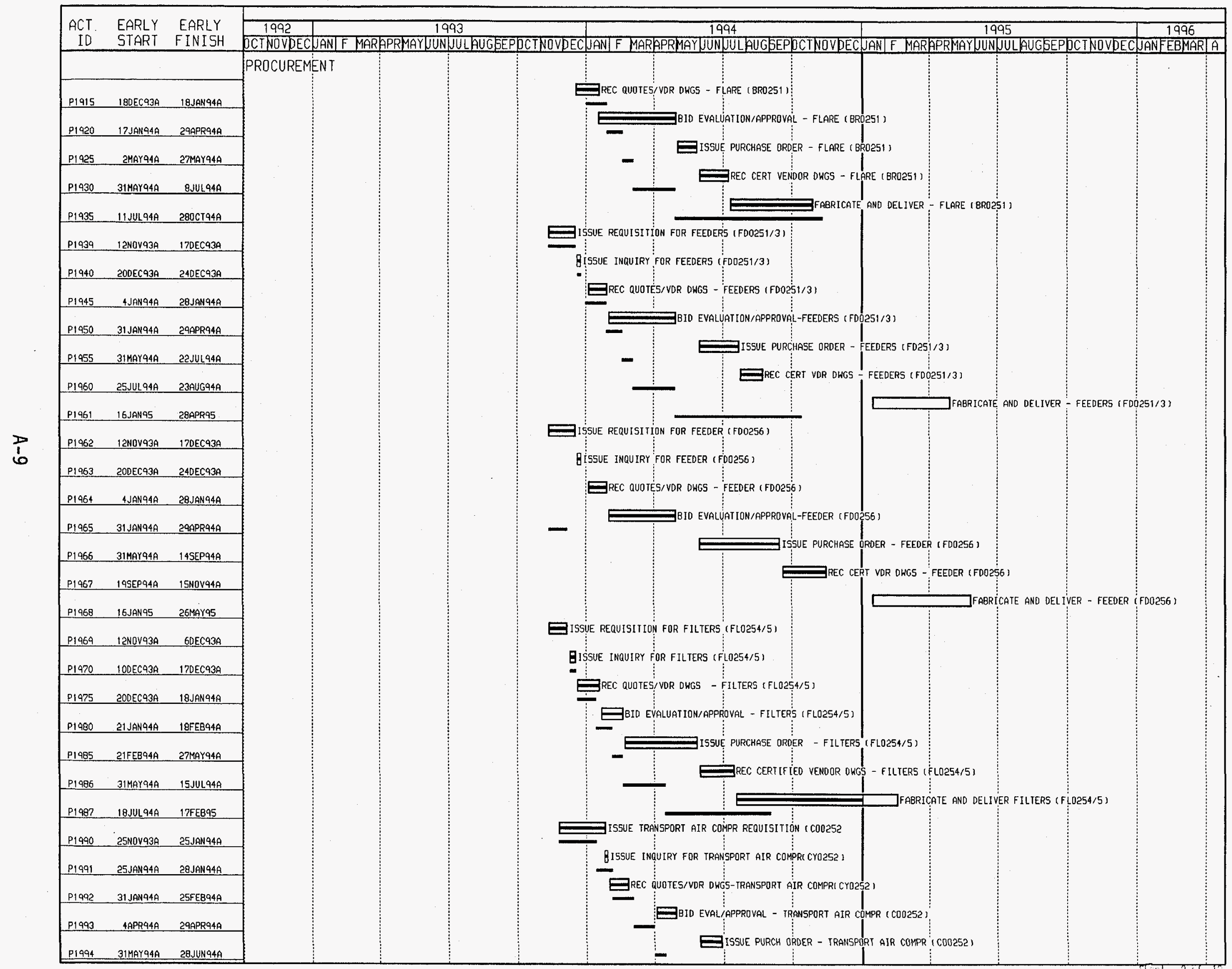




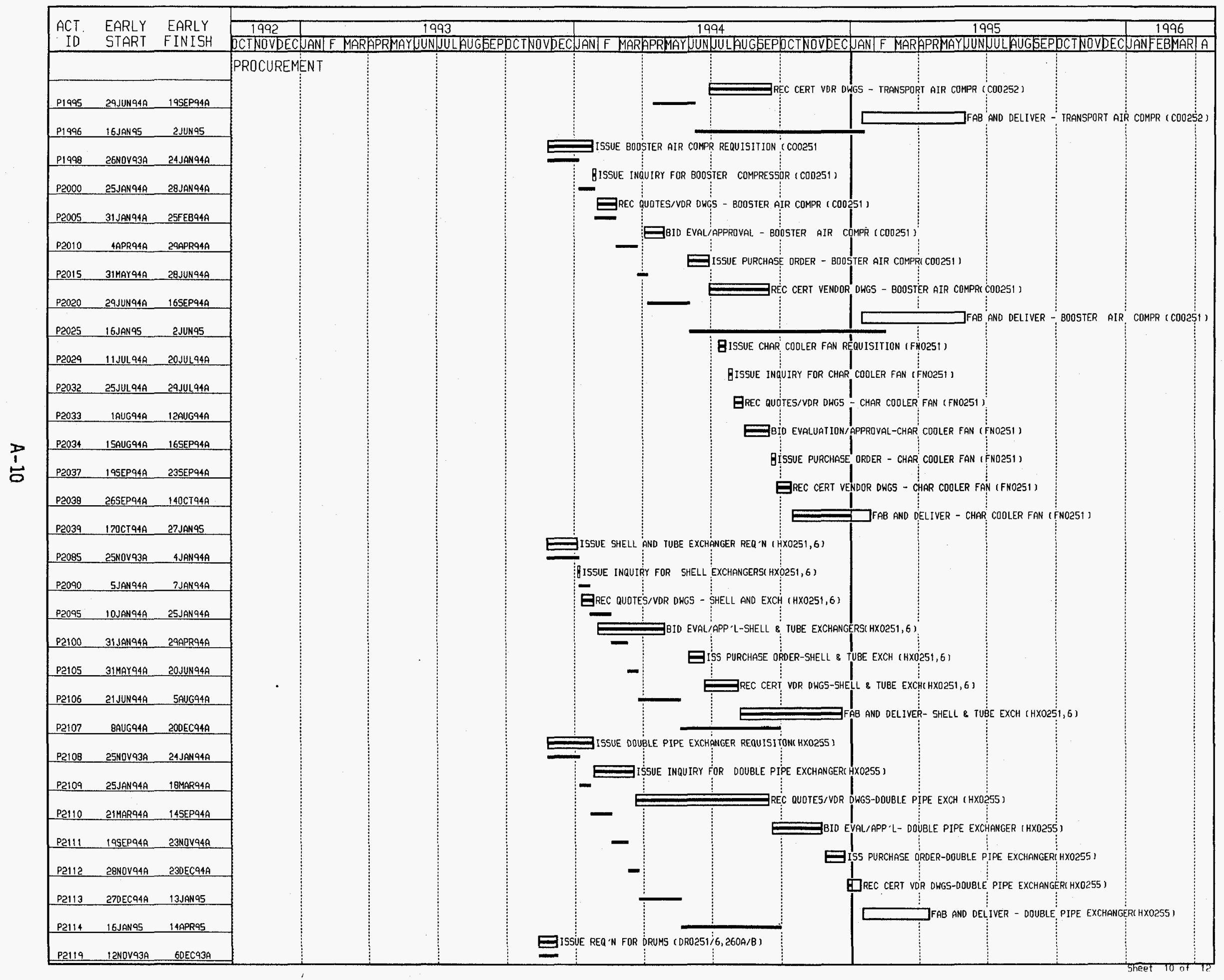




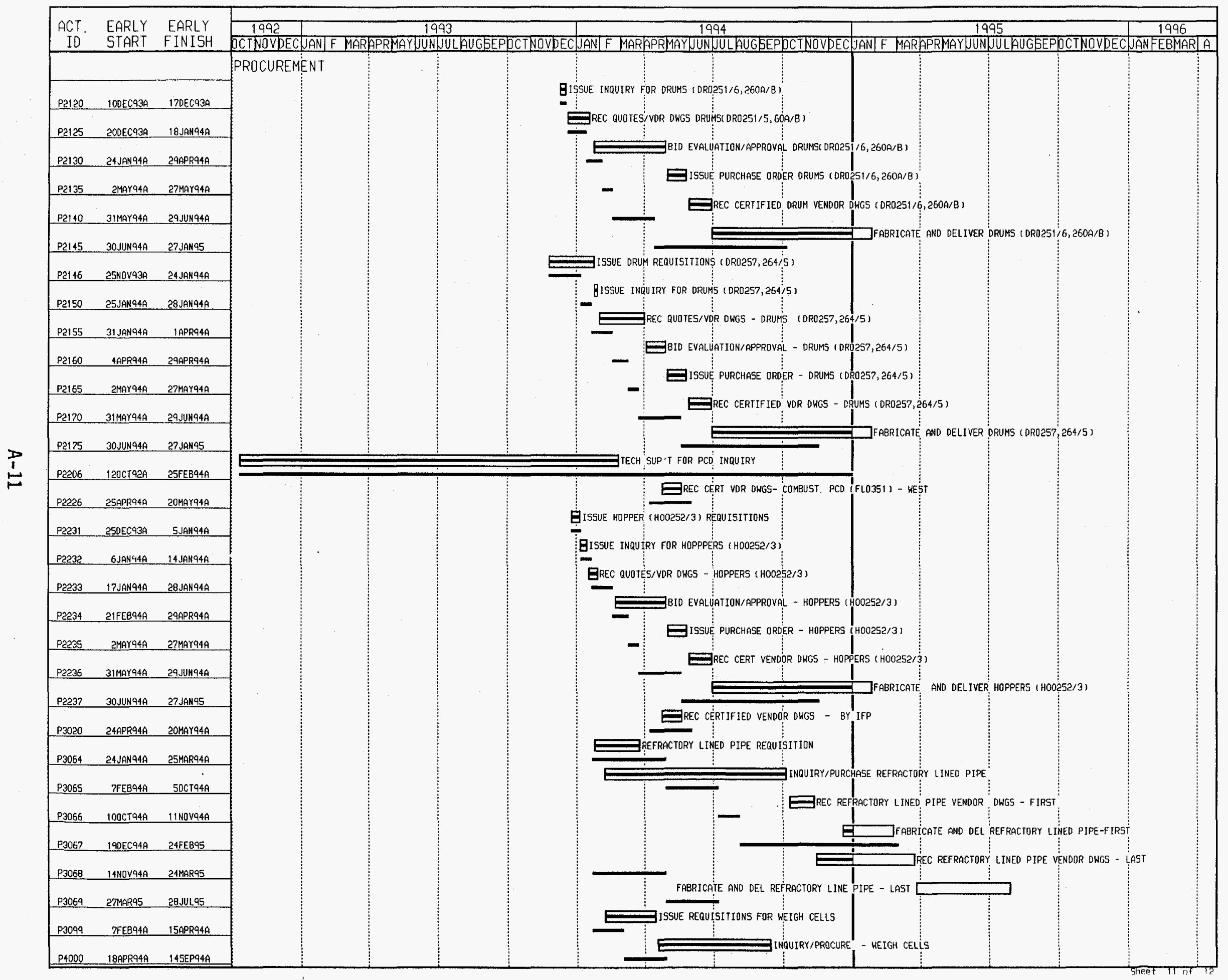




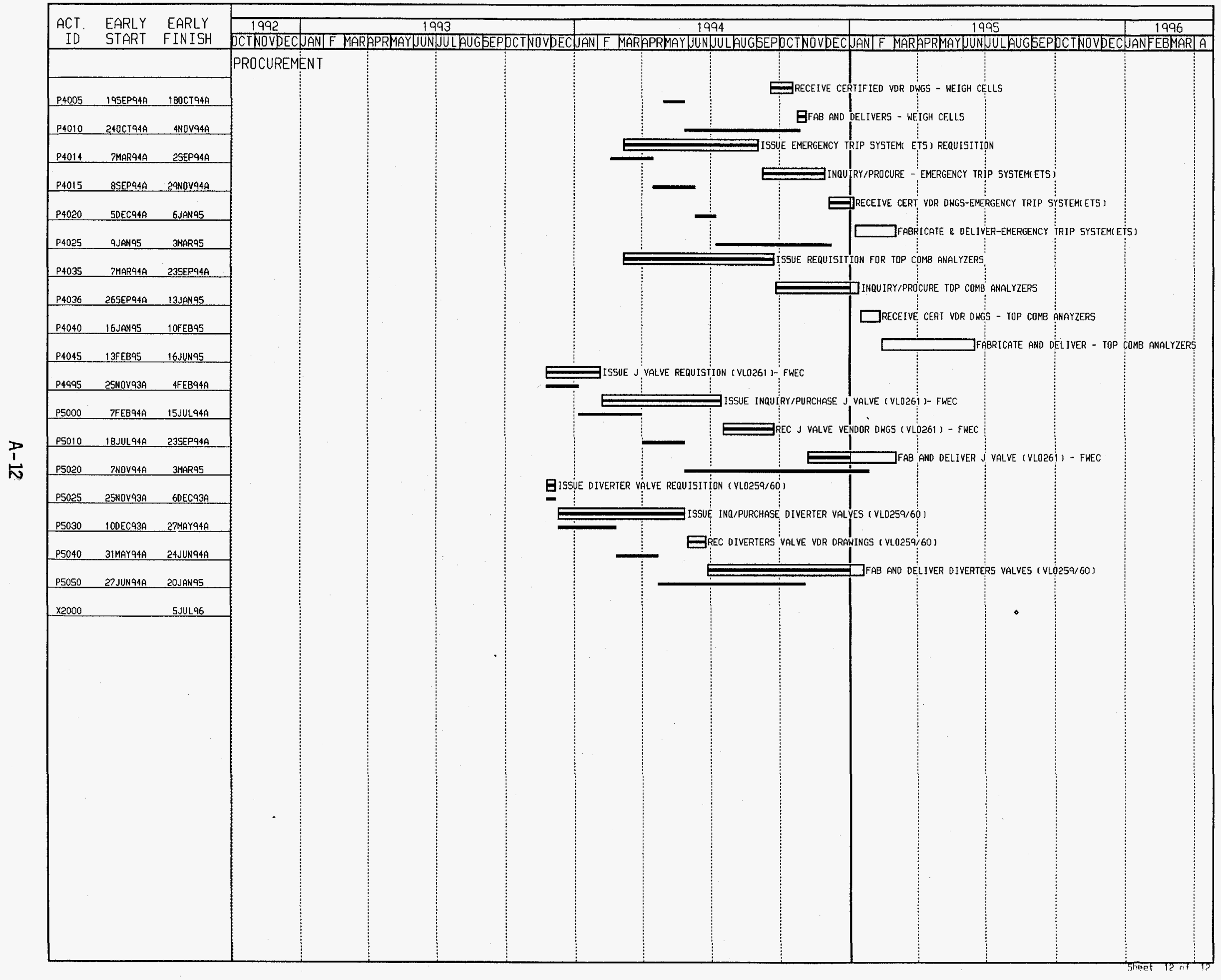


APPENDIX B

AGENDA FROM THE FW/SCS DETAILED DESIGN MEETING HELD ON NOVEMBER 15-17, 1994 


\title{
Foster Wheeler/SCS Detailed Design Discussions November 15-17, 1994 \\ Livingston, New Jersey
}

\section{November 15 and 16:}

Detailed design review between FW and SCS personnel, by discipline. This will be in "breakout" meetings. A list of suggested topics is attached, however, each FW/SCS discipline should discuss with their counterpart at SCS/FW what the individual discussions will involve, prior to the meetings, so all will be prepared for a productive working session.

\author{
David Elmore/Danny Burnette (civil) \\ Greg Mann/Terry Hulsey (mechanical) \\ Jimmy Horton (instrument) \\ King Knight/Ken Walker/Scott Jackson (electrical)
}

\section{November 16:}

Design Hazard Review discussions between FW (Naba Chakraborty, John Hemmings, Norm Feinberg) and John Wheeldon/Darrell Moore.

P\&ID Review/Comments, if warranted. This may need to take place later, after the Design Hazard Review recommendations are further along the completion curve.

\section{November 17:}

This day will resolve any unsettled or controversial outstanding issues from other meetings, as well as anything else project management wishes to discuss, but will include the following:

- Management review of design status (based on breakout meetings held earlier in the week), including:

- Manhours expended vs. budgeted, by discipline.

- Percent completion for each detail design area/activity, by discipline

- Remaining schedule for each design area

- Status of refractory lined pipe design, fabrication, and delivery

- Westinghouse and Allison

- Contract/purchase order status

- Detail design schedule and discussion of design issues and questions

- Review and resolution of unresolved design hazard review items

- Scope of supply issues (if any), including "deliverables" and their content

- P\&ID comment issues, including "final" P\&ID issue date

- Preliminary discussion on design closeout schedule 


\subsection{Detailed Design Review}

Discuss the status of detailed design, including reviewing the drawings or other documentation to ensure SCS and FW are in agreement on what is to be delivered, including content and schedule. Determine for each discipline the level of completeness of each design task (or group of tasks), the schedule FW has on the table for that task, and how that fits in with SCS design and/or construction requirements.

\subsection{Structural and Detailed Piping Design}

1. Equipment layout

2. PDS model of equipment and piping

3. Plan and elevation drawings

4. Pipe stress analysis

5. Status of equipment design and delivery

6. Refractory-lined piping layout and isometrics

7. Status of piping design and delivery

8. CS piping isometrics and pipe support details

9. Piping material takeoff

\subsection{Detailed Electrical Design}

1. Electrical specifications

2. Equipment load calculations

3. Elementary control diagrams

4. Power and control wiring plan

5. Power and/or control tray plans

6. Circuit naming, raceway naming, circuit routing and schedule, raceway schedule etc.

7. Cable specifications and requirements

8. Instrument cable tray plans

9. Wiring installation details

10. Interconnecting wiring diagrams

11. Emergency trip system ladder diagrams and drawings

12. PCD interface

13. Freeze protection

14. Process and hopper cone heat

15. VSD status

16. Generator reverse power

17. Allison/USTC interface

18. Electrical material takeoff 


\subsection{Detailed Instrument Design}

1. Instrument installation \& support details

2. Instrumentation requisitions

3. SAMA configuration drawings

4. Sequence control diagrams

5. Instrument location plans

6. Logic diagrams

7. Point-to-point wiring diagrams

8. IRS review

9. Database structure for configuration

10. Process analyzer design and procurement responsibility and status

11. Instrument material takeoff

\subsection{Review of Design Hazard Review}

Reach agreement on each item listed from the review, or assign responsibility for resolution within a reasonable time period. Also, identify remaining components for review, and when the review should be conducted. Unsettled or controversial items can be discussed with George Griswold and Jim Crumm.

\subsection{P\&ID Comments}

If time permits, discuss the status of P\&ID development, including incorporation of SCS comments from earlier issues that are still appropriate but have not yet been addressed. Also, review the status of the following:

1. FW/SCS interface lists

2. Overall plant control philosophy (including FWEC system)

3. Operating logic descriptions

4. Interlock logic diagrams. 
APPENDIX C

FW APFBC SYSTEM:

TOPPING COMBUSTOR/GAS TURBINE PIPING SYSTEM 
December 14, 1994

Letter No. 2.1-665

File No(s). 2.1

Southern Company Services, Inc.

Post Office Box 2625

Birmingham, AL 35202

Attention: $\quad$ Mr. Darrell L Moore

Contract Administrator

Subject:

FW Job No. $15-4161$

SCS PSD Facility - APFBC System

TOPPING COMBUSTOR/GAS TURBINE PIPING SYSTEM

Dear Mr. Moore:

In accord with recent discussions between FW USA and SCS, Westinghouse and Allison, FW USA has opted to take full design responsibility for all piping from the alkali gitters tifrough the topping combustor and into the gas turbine. FW USA has been responsible for all of the piping except a short transition piece between the topping combustor and the gas turbine since the original conceptual package (Phase 1). FW USA decision to take over responsibility for the one remaining piece of pipe is two fold.

Allison has expressed a reluctance to take responsibility for this "pipe spool" and had, therefore, placed an exceedingly large contingency factor on the spool's price, approximately $\$ 500,000$. However, the over-riding reason for FW USA's decision is that FW USA is responsible for the design of everything else in this extremely complicated piping system that runs from the alkali gutter outlets to the topping combustor including the quench/venting systems, the topping combustor with its three air recycle lines from the gas turbine compressor, the steam system and propane fuel system that ties into the topping combustor, the quench air system after the topping combustor. This system must be modelled for pipe stress as a single system under one company's control. Since the spool in Allison's original scope is only five to ten feet long it makes no sense for them to be involved in the piping system. 
Mr. D. Moore

Letter No. 2.1-665

December 14, 1994

Page 2

It should be noted that the pipe spool in question has nothing to do with the scroll assembly at the inlet to Allison's gas turbine/compressor system. This item is still completely within Allison's scope of supply.

All of the above was reviewed during our recent review/coordination meeting on November 17,1994. As we discussed, in our purchase order with Allison we intend to exercise the option for the take out price for the spool. If you have any questions please do not hesitate to contact me.

Very truly yours,

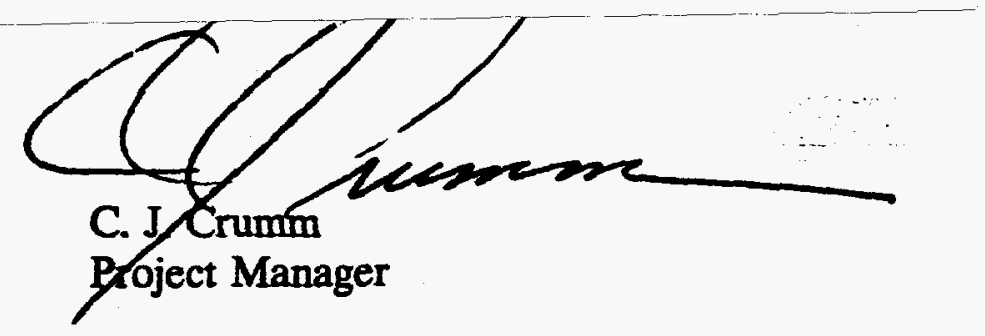

CJC:ljs

R:ISOUTHERN|665.2-1

cc: $\quad \underline{\text { SCS }}$

EW

G. Griswold

N. Chakraborty

J. Hemmings

D. Lock

D. Richard 


\section{APPENDIX D}

FW APFBC SYSTEM:

EXPANSION JOINTS IN LINED PIPES 
October 21, 1994

Letter No. 2.1-616

File No.(s)2.1, 8.59

Southern Company Services, Inc.

Post Office Box 2625

Birmingham, AL 35202

Attention: $\quad$ Mr. Darrell L. Moore

Contracts Administrator

Subject:

FW Job No. 15-4161

SCS PSD Facility-APFBC System

EXPANSION JOINTS IN LINED PIPES

Dear Mr. Moore:

Attached is a copy of Chen/Chakraborty IOC dated October 14, 1994, the contents of which are self-explanatory.

Very truly yours,

CJCWNClcc

Attachment

A:LTR\#616.NC

cc: $\underline{\text { SCS }}$

FW

G. Griswold

N. Chakraborty

M. Chen

J. McClung

M. Quandt

D. Richard 
INTER OFFICE CORRESPONDENCE

\author{
October 14,1994
}

$\begin{array}{ll}\text { TO: } & \text { N. K. Chakraborty } \\ \text { FROM: } & \text { M. Y. Chen } \\ \text { CC: } & \text { A. S. Malsbury } \\ & \text { R. S. Kirk } \\ \text { J. L. Blough } \\ \text { N. Feinberg } \\ \text { E. Ghali } \\ \text { T. Kucharyk } \\ \text { M. Quandt } \\ \text { FW USA Contract 13004161 } \\ \text { SCS PDS Facility - APFBC SYstem } \\ \text { SUBJECT : } & \text { EXPANSION JOINTS IN REFRACTORY LINED PIPING }\end{array}$

There are three expansion joints in the carbonizer train and four expansion joints in the combustor train of the current refractory lined piping system. A review of possible corrosion attack on these expansion joints with our metallurgists concludes the following.

1. The construction material of all expansion joint bellows shall be Inconel 625 LCF.

2. All the bellows shall be two-ply testable with leak detector between plies.

3. In TIDD plant operating experience, expansion joints with internal insulation of ceramic fiber blanket and without bellows external insulation were used in the oxidizing flue gas system. The flue gas, containing corrosive gases $\mathrm{SO}_{2}$ and $\mathrm{SO}_{3}$, penetrated the ceramic fiber blanket and condensed on the cold bellows wall and corroded through the bellows thickness within a few days. Foster wheeler USA standard expansion joint design employs impervious castable refractory for the internal insulation and ceramic fiber blanket for the external insulation. The internal castable refractory will minimize the migration of corrosive gases to the bellows. The external blanket insulation is designed to maintain bellows temperature 
between 400 and $800^{\circ} \mathrm{F}$ (gas dew point is below $375^{\circ} \mathrm{F}$ ) to prevent any possible gas condensation in the event the gas finds its way to the bellows wall.

4. Considering the aggressive corrosion attack experienced in the TIDD plant, it is also recommended a set of thermocouples be attached to each bellows in oxidizing combustor train. These thermocouples will provide the actual bellows metal temperatures to ensure gas condensation will not take place. Our experience in the reducing environment service similar to the carbonizer train showed that condensation corrosion is not a problem with the material Inconel 625 for design life of 2000 hours. Therefore the thermocouple is considered not necessary for the expansion joints in the reducing carbonizer train when the design precautions as stated in 3. are implemented.

If you have any questions please contact us.

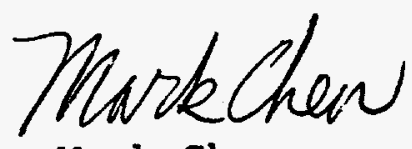

Mark Chen 


\section{APPENDIX E}

FW APFBC SYSTEM: PCD TEMPERATURE 
November 11, 1994

Letter No. 2.1-636

File No.(s)2.1

Southern Company Services, Inc.

Post Office Box 2625

Birmingham, AL 35202

Aftention: $\quad$ Mr. Darrell L. Moore

Contracts Administrator

Subject:

FW Job No. 15-4161

SCS PSD FACILITY-APFBC SYSTEM

PCD TEMPERATURE

Dear Mr. Moore:

As requested by SCS during a telephone discussion involving Rich Dennis (DOE), Zia Haq (SCS), John Wheeldon (EPRI) and John Hemmings (FW), the transient behavior of the gas temperature at the inlet and outlet of the carbonizer PCD has been evaluated. This is intended to establish a design basis for Oakridge National Laboratories to use as input for analysis of tubesheet stress in the IF\&P PCD, which they are performing under a DOE contract.

Three cases have been considered in our evaluation:

1. Loss of coal.

2. Loss of air (with a limited nitrogen flow automatically established to maintain fluidization).

3. PCD regeneration.

The results for the above three situations in terms of a design basis for the PCD tubesheet study are as follows:

A. In the case of loss of coal feed, the inlet gas temperature starts out at $1700^{\circ} \mathrm{F}$. Then at time zero ramps up at $40^{\circ} \mathrm{F}$ per minute until the trip temperature of $1850^{\circ} \mathrm{F}$ is reached. The temperature thereafter declines at a rate of $-100^{\circ} \mathrm{F}$ per minute for three minutes and at $-20^{\circ} \mathrm{F}$ per minute thereafter. The outlet gas temperature follows the inlet.

B. In the case of loss of air, the inlet gas temperature starts out at $1700^{\circ} \mathrm{F}$. Then at time zero it declines at $-150^{\circ} \mathrm{F}$ per minute for three minutes, thereafter at $-20^{\circ} \mathrm{F}$ per minute. The outlet gas temperature follows the inlet. 
Southern Company Services, Inc.

November 11, 1994

Attention: Mr. D. Moore

Letter No. 2.1-636

File No(s). 2.1

C. In the case of PCD regeneration the outlet gas temperature averages $1700^{\circ} \mathrm{F}$. It is subjected to a saw tooth temperature variation, consisting of a sudden drop of $200^{\circ} \mathrm{F}$ to $300^{\circ} \mathrm{F}$, followed by a rebound to the starting temperature at $10^{\circ} \mathrm{F}$ to $20^{\circ}$ per second for 20 seconds. This pattern repeats 6 times in succession (initial drops at 20 second intervals, corresponding to the admission of nitrogen pulses). The temperature then remains at $1700^{\circ} \mathrm{F}$ for 330 seconds. Thereafter the entire pattern is repeated. The inlet gas temperature may be assumed to remain at $1700^{\circ} \mathrm{F}$ throughout the disturbance.

We trust that this information is suitable for your requirements and request that you transmit it on to DOE.

Very truly yours,

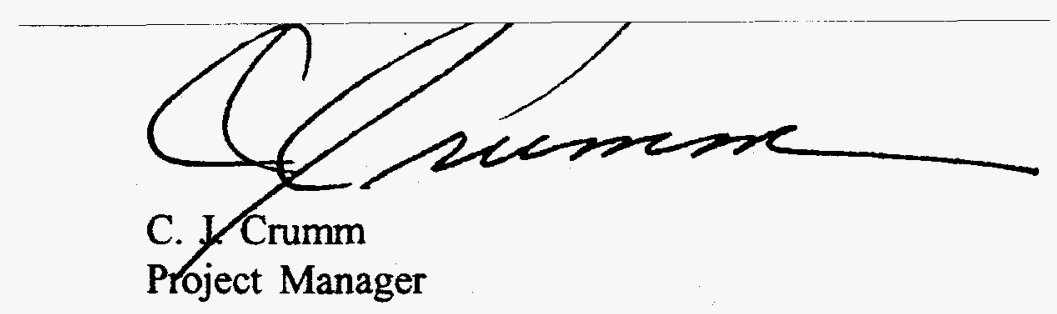

CJCUWHYad

Attachment

A:LIR\#636.NC

cc: $\quad \underline{\text { SCS }}$

$\underline{\text { FW }}$

G. Griswold

N. Chakraborty

J. Hemmings

J. McClung

M. Quandt

D. Richard 


\section{APPENDIX F}

FW APFBC TRAIN:

DETAILED COMPONENT SCHEDULE 
Southern Company Services PDS Facility

C OMPONENT SCHEDULE

EQUIPMENT LIST REVISION DATED - $7 / 19 / 94$

FOSTER HHEELER USA CORP Report SCSOCT Page 1 File SCSCS.R2D 1/09/95 FWUSA Project 115-00-04160 Sort ELCLASS/ITEM Actuals thru: 30-Dec-94

\begin{tabular}{|c|c|c|c|c|c|c|c|c|c|c|c|c|c|c|c|}
\hline $\begin{array}{l}\text { ITEM } \\
\text { ITEM DESC } \\
\text { Comment }\end{array}$ & QTY & SPEC/REQ & INO \# & PO \# & $\begin{array}{c}\text { FW } \\
\text { ISSUE } \\
\text { SPEC/ } \\
\text { REQ }\end{array}$ & $\begin{array}{c}\text { SCS } \\
\text { APPROVE } \\
\text { SPEC/ } \\
\text { REQ }\end{array}$ & $\begin{array}{c}\text { FH } \\
\text { ISSUE } \\
\text { INQUIRY/ } \\
\text { RFQ }\end{array}$ & $\begin{array}{l}\text { FW } \\
\text { RECEIVE } \\
\text { BIDS/ } \\
\text { QUOTES }\end{array}$ & $\begin{array}{l}\text { FW } \\
\text { COMPLETE } \\
\text { BID } \\
\text { TABS }\end{array}$ & $\begin{array}{c}\text { SCS } \\
\text { BID } \\
\text { TAB } \\
\text { APPROVAL }\end{array}$ & $\begin{array}{l}\text { FW } \\
\text { RELEASE } \\
\text { PURCHASE } \\
\text { ORDER }\end{array}$ & $\begin{array}{c}\text { FW } \\
\text { RECEIVE } \\
\text { VENDOR } \\
\text { ORAWINGS }\end{array}$ & $\begin{array}{c}\text { SHIP } \\
\text { F.O.B. }\end{array}$ & \begin{tabular}{|} 
DEL IVERY \\
TO \\
SITE/SHOP
\end{tabular} & $\begin{array}{l}\text { FIELD } \\
\text { NEED } \\
\text { SLACK } \\
\text { (IN WKS) }\end{array}$ \\
\hline
\end{tabular}

EQUIPMENT LIST CLASS: EXCHANGERS

\begin{tabular}{|c|c|c|c|c|c|c|c|c|c|c|c|c|c|c|c|c|}
\hline $\begin{array}{l}\text { HX0251 } \\
\text { Process Air Cooler }\end{array}$ & 1 & $1211 \mathrm{~A}$ & 109 & PP-9 & $\begin{array}{r}P \\
A / F\end{array}$ & $\left|\begin{array}{c}1 / 03 / 94 \\
1 / 04 / 94 \mathrm{~A} \\
\end{array}\right|$ & $\mid \begin{array}{c}1 / 17 / 94 \\
1 / 06 / 94 \mathrm{~A} \\
= \pm=E= \pm= \pm\end{array}$ & 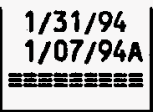 & $\mid \begin{array}{c}2 / 28 / 94 \\
1 / 25 / 94 \mathrm{~A} \\
2= \pm 0= \pm\end{array}$ & $\begin{array}{l}3 / 14 / 94 \\
2 / 25 / 94 \mathrm{~A} \\
\end{array}$ & $\begin{array}{l}3 / 28 / 94 \\
4 / 29 / 94 \mathrm{~A} \\
=\end{array}$ & $\left|\begin{array}{c}4 / 11 / 94 \\
6 / 20 / 94 A \\
0\end{array}\right|$ & $\begin{array}{c}6 / 06 / 94 \\
8 / 05 / 94 A \\
\end{array}$ & $\left|\begin{array}{c}9 / 19 / 94 \\
12 / 20 / 94 \mathrm{~A} \\
\end{array}\right|$ & $\left|\begin{array}{l}10 / 03 / 94 \\
12 / 27 / 94 A \\
12 / 94\end{array}\right|$ & $\begin{array}{r}12 / 14 / 94 \\
12 / 14 / 94 \\
-2\end{array}$ \\
\hline $\begin{array}{l}\text { HX0255 } \\
\text { Char Cooler } \\
\text { Re-Design }\end{array}$ & 1 & $1221 \mathrm{~A}$ & 120 & PP-19 & $\begin{array}{r}P \\
A / F\end{array}$ & $\mid \begin{array}{c}1 / 03 / 94 \\
1 / 24 / 94 \mathrm{~A} \\
1\end{array}$ & $\begin{array}{c}1 / 17 / 94 \\
1 / 25 / 94 \mathrm{~A} \\
= \pm\end{array}$ & $\mid \begin{array}{c}1 / 31 / 94 \\
3 / 18 / 94 \mathrm{~A} \\
0\end{array}$ & $\mid \begin{array}{l}2 / 16 / 94 \\
4 / 01 / 94 \mathrm{~A} \\
2\end{array}$ & $\begin{array}{l}\text { 3/02/94 } \\
4 / 15 / 94 \mathrm{~A} \\
\end{array}$ & \begin{tabular}{|c|}
$3 / 16 / 94$ \\
$4 / 29 / 94 \mathrm{~A}$ \\
$= \pm= \pm$
\end{tabular} & $\left|\begin{array}{c}3 / 30 / 94 \\
12 / 23 / 94 \mathrm{~A} \\
\mid\end{array}\right|$ & $\begin{array}{l}5 / 25 / 94 \\
1 / 06 / 95\end{array}$ & $\begin{array}{l}9 / 07 / 94 \\
4 / 07 / 95\end{array}$ & $\begin{array}{l}9 / 21 / 94 \\
4 / 14 / 95\end{array}$ & $\begin{array}{r}8 / 07 / 95 \\
8 / 07 / 95 \\
16\end{array}$ \\
\hline $\begin{array}{l}\text { HX0256 } \\
\text { Air Heater }\end{array}$ & 1 & 1211E & 109 & 0.9 & $\begin{array}{r}P \\
A / F\end{array}$ & 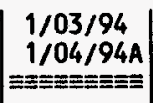 & $\mid$\begin{tabular}{c|}
$1 / 17 / 94$ \\
$1 / 06 / 94 \mathrm{~A}$ \\
$=\equiv=\equiv= \pm= \pm$
\end{tabular} & $\mid \begin{array}{l}1 / 31 / 94 \\
1 / 07 / 94 \mathrm{~A} \\
= \pm= \pm\end{array}$ & $\mid \begin{array}{l}2 / 28 / 94 \\
1 / 25 / 94 \mathrm{~A} \\
\end{array}$ & $\begin{array}{l}3 / 14 / 94 \\
2 / 25 / 94 \mathrm{~A} \\
\end{array}$ & $\begin{array}{l}3 / 28 / 94 \\
4 / 29 / 94 \mathrm{~A} \\
\end{array}$ & $\left|\begin{array}{l}4 / 11 / 94 \\
6 / 20 / 94 \mathrm{~A} \\
2=\end{array}\right|$ & $\begin{array}{r}6 / 06 / 94 \\
8 / 05 / 94 \mathrm{~A} \\
\end{array}$ & $\mid \begin{array}{c}9 / 19 / 94 \\
12 / 20 / 94 \mathrm{~A} \\
\end{array}$ & 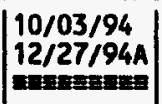 & $\begin{array}{r}12 / 14 / 94 \\
12 / 14 / 94 \\
-2\end{array}$ \\
\hline
\end{tabular}

Ti EQUIPMENT LIST CLASS: FBHE PACKAGE (BY FWEC)

\begin{tabular}{|c|c|c|c|c|c|c|c|c|c|c|c|c|c|}
\hline $\begin{array}{l}\text { CY0252 } \\
\text { Combustor Cyclone }\end{array}$ & $1 \quad 1291 \mathrm{~A}$ & $\mathbf{A} / \mathbf{P}$ & \begin{tabular}{|l|}
$1 / 03 / 94$ \\
$1 / 31 / 94 \mathrm{~A}$ \\
$=0= \pm$
\end{tabular} & $\mid \begin{array}{l}1 / 17 / 94 \\
2 / 04 / 94 \mathrm{~A} \\
\end{array}$ & $\begin{array}{l}1 / 24 / 94 \\
2 / 11 / 94 \mathrm{~A} \\
2\end{array}$ & $\begin{array}{l}2 / 21 / 94 \\
2 / 25 / 94 \mathrm{~A}\end{array}$ & $\mid \begin{array}{l}3 / 07 / 94 \\
3 / 25 / 94 \mathrm{~A} \\
\end{array}$ & $\begin{array}{c}3 / 21 / 94 \\
4 / 29 / 94 \mathrm{~A} \\
\end{array}$ & $\left|\begin{array}{c}4 / 04 / 94 \\
7 / 15 / 94 A \\
0\end{array}\right|$ & \begin{tabular}{|l|}
$5 / 30 / 94$ \\
$8 / 19 / 94 \mathrm{~A}$ \\
8
\end{tabular} & $\begin{array}{l}1 / 09 / 95 \\
2 / 17 / 95\end{array}$ & $\begin{array}{l}1 / 23 / 95 \\
2 / 24 / 95\end{array}$ & $\begin{array}{r}8 / 07 / 95 \\
8 / 07 / 95 \\
23\end{array}$ \\
\hline $\begin{array}{l}\text { HX0253 } \\
\text { Fludized Bottom Ash }\end{array}$ & $\begin{array}{l}11291 \mathrm{~A} \\
\text { Cooler }\end{array}$ & $\begin{array}{r}P / F \\
A\end{array}$ & $\begin{array}{l}1 / 03 / 94 \\
1 / 31 / 94 \mathrm{~A} \\
\end{array}$ & $\mid$\begin{tabular}{c|}
$1 / 17 / 94$ \\
$2 / 04 / 94 \mathrm{~A}$ \\
210
\end{tabular} & $\begin{array}{c}1 / 31 / 94 \\
2 / 11 / 94 \mathrm{~A} \\
= \pm= \pm \equiv \equiv \equiv\end{array}$ & $\begin{array}{l}2 / 28 / 94 \\
2 / 25 / 94 \mathrm{~A} \\
2\end{array}$ & $\begin{array}{c}3 / 14 / 94 \\
3 / 25 / 94 \mathrm{~A} \\
3 / 25 / 9\end{array}$ & $\mid \begin{array}{l}3 / 28 / 94 \\
4 / 29 / 94 \mathrm{~A} \\
2\end{array}$ & $\left|\begin{array}{c}4 / 11 / 94 \\
7 / 15 / 94 A \\
\mid\end{array}\right|$ & \begin{tabular}{|}
$6 / 06 / 94$ \\
$8 / 26 / 94 A$ \\
8
\end{tabular} & $\begin{array}{l}1 / 02 / 95 \\
2 / 03 / 95\end{array}$ & $\begin{array}{l}1 / 16 / 95 \\
2 / 10 / 95\end{array}$ & $\begin{array}{r}5 / 08 / 95 \\
5 / 08 / 95 \\
12\end{array}$ \\
\hline $\begin{array}{l}\text { LP1102 } \\
\text { FBHE Ash Lined Pipe }\end{array}$ & $\begin{array}{l}1 \\
\text { To Combustor }\end{array}$ & $\begin{array}{r}P \\
A / F\end{array}$ & 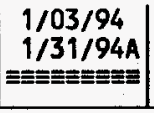 & $\mid$\begin{tabular}{c|}
$1 / 17 / 94$ \\
$2 / 04 / 94 \mathrm{~A}$ \\
$2 / 2$
\end{tabular} & 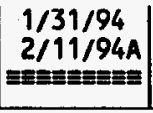 & $\begin{array}{l}2 / 28 / 94 \\
2 / 25 / 94 A \\
2\end{array}$ & $\mid \begin{array}{c}3 / 14 / 94 \\
3 / 25 / 94 \mathrm{~A} \\
\end{array}$ & 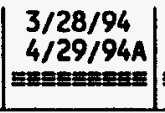 & $\mid \begin{array}{l}4 / 11 / 94 \\
7 / 15 / 94 \mathrm{~A} \\
\end{array}$ & $\mid \begin{array}{c}6 / 06 / 94 \\
10 / 17 / 94 \mathrm{~A} \\
\\
\end{array}$ & $\begin{array}{l}1 / 02 / 95 \\
5 / 05 / 95\end{array}$ & $\begin{array}{l}1 / 16 / 95 \\
5 / 12 / 95\end{array}$ & $\begin{array}{r}2 / 13 / 95 \\
2 / 13 / 95 \\
-13 \\
\end{array}$ \\
\hline $\begin{array}{l}\text { PG0251 } \\
\text { FBHE Package }\end{array}$ & $1291 \mathrm{~A}$ & $\begin{array}{r}P \\
A / F\end{array}$ & $\begin{array}{c}12 / 24 / 93 \\
1 / 31 / 94 \mathrm{~A} \\
\equiv \equiv \equiv \equiv \equiv \equiv \equiv\end{array}$ & $\mid \begin{array}{c}1 / 07 / 94 \\
2 / 04 / 94 \mathrm{~A} \\
=\end{array}$ & $\begin{array}{r}1 / 14 / 94 \\
2 / 11 / 94 \mathrm{~A} \\
\end{array}$ & $\begin{array}{c}2 / 11 / 94 \\
2 / 25 / 94 \mathrm{~A} \\
\end{array}$ & $\begin{array}{c}2 / 25 / 94 \\
3 / 25 / 94 \mathrm{~A} \\
\end{array}$ & $\left|\begin{array}{c}3 / 11 / 94 \\
4 / 29 / 94 \mathrm{~A} \\
\end{array}\right|$ & $\mid \begin{array}{c}3 / 25 / 94 \\
7 / 15 / 94 \mathrm{~A} \\
\end{array}$ & $\left|\begin{array}{c}5 / 20 / 94 \\
10 / 14 / 94 a \\
01=0\end{array}\right|$ & $\begin{array}{l}1 / 31 / 95 \\
4 / 19 / 95\end{array}$ & $\begin{array}{l}2 / 14 / 95 \\
4 / 26 / 95\end{array}$ & $\begin{array}{r}6 / 20 / 95 \\
6 / 20 / 95 \\
8\end{array}$ \\
\hline $\begin{array}{l}\text { RX0252 } \\
\text { Combustor }\end{array}$ & $1291 \mathrm{~A}$ & $\begin{array}{r}P \\
A / F\end{array}$ & $\mid \begin{array}{c}12 / 24 / 93 \\
1 / 31 / 94 \mathrm{~A} \\
1 / 129\end{array}$ & \begin{tabular}{|c|}
$1 / 07 / 94$ \\
$2 / 04 / 94 \mathrm{~A}$ \\
$\equiv=0$
\end{tabular} & 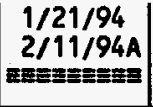 & $\begin{array}{c}2 / 18 / 94 \\
2 / 25 / 94 A \\
2 / 2519\end{array}$ & $\mid \begin{array}{c}3 / 04 / 94 \\
3 / 25 / 94 \mathrm{~A} \\
3 / 25 / 2\end{array}$ & $\mid \begin{array}{l}3 / 18 / 94 \\
4 / 29 / 94 \mathrm{~A} \\
2\end{array}$ & $\mid$\begin{tabular}{c|}
$4 / 01 / 94$ \\
$7 / 15 / 94 A$ \\
Ez:menas
\end{tabular} & $\left|\begin{array}{c}5 / 27 / 94 \\
10 / 14 / 94 \mathrm{~A} \\
0\end{array}\right|$ & $\begin{array}{l}2 / 21 / 95 \\
3 / 22 / 95\end{array}$ & $\begin{array}{l}3 / 07 / 95 \\
3 / 29 / 95\end{array}$ & $\begin{array}{r}5 / 08 / 95 \\
5 / 08 / 95 \\
6\end{array}$ \\
\hline $\begin{array}{l}\text { VL0261 } \\
\text { Combustor Cyclone J }\end{array}$ & $\begin{array}{l}1 \text { 1291A } \\
\text { Valve }\end{array}$ & $\begin{array}{r}P \\
A / F\end{array}$ & 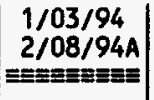 & $\mid$\begin{tabular}{c|}
$1 / 17 / 94$ \\
$2 / 08 / 94 \mathrm{~A}$ \\
$2 / 0$
\end{tabular} & 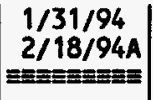 & 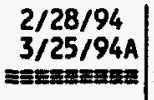 & $\mid \begin{array}{c}3 / 14 / 94 \\
4 / 15 / 94 \mathrm{~A} \\
\end{array}$ & $\mid \begin{array}{l}3 / 28 / 94 \\
4 / 29 / 94 \mathrm{~A} \\
=\end{array}$ & 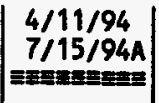 & $\begin{array}{l}6 / 06 / 94 \\
9 / 23 / 94 \mathrm{~A} \\
9 / 2\end{array}$ & $\begin{array}{l}1 / 16 / 95 \\
2 / 24 / 95\end{array}$ & $\begin{array}{l}1 / 30 / 95 \\
3 / 03 / 95\end{array}$ & $\begin{array}{r}8 / 07 / 95 \\
8 / 07 / 95 \\
22\end{array}$ \\
\hline
\end{tabular}

EQUIPMENT LIST CLASS: MECHANICAL EQUIPMENT

FLO351

Carbonizer

By I.F.P.

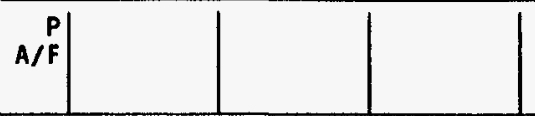




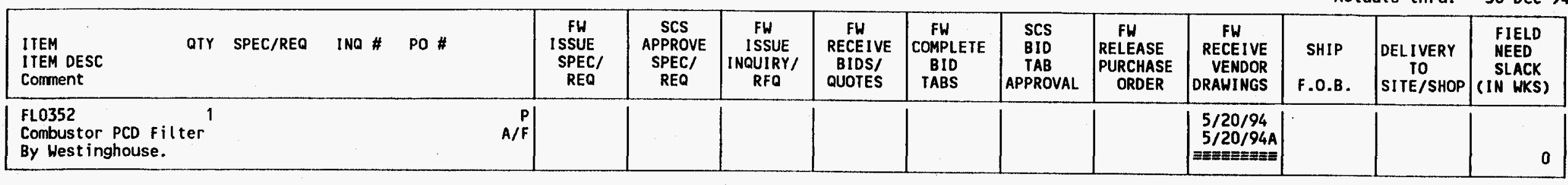

EQUIPMENT LIST CL.ASS: MECHANICAL - ALLLISON

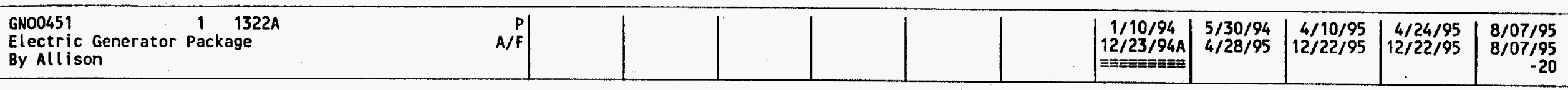

EQUIPMENT LIST CLASS: MECHANICAL - MATERIAL HANDLING

\begin{tabular}{|c|c|c|c|c|c|c|c|c|c|c|c|c|c|c|}
\hline $\begin{array}{l}\text { Fl0253 } \\
\text { Fugitive Dust Bag House } \\
\text { Deleted }\end{array}$ & & & $\begin{array}{r}P \\
A / F\end{array}$ & & & & & & & & & & & 0 \\
\hline $\begin{array}{l}\text { Fl.0254 } \\
\text { Coal Surge Hopper Filter }\end{array}$ & 104 & PP-8 & $\begin{array}{r}P \\
A / F\end{array}$ & $\mid \begin{array}{l}12 / 06 / 93 \\
12 / 06 / 93 \mathrm{~A} \\
\equiv \equiv \equiv= \pm= \pm=\equiv\end{array}$ & $\begin{array}{l}12 / 20 / 93 \\
12 / 13 / 93 \mathrm{~A} \\
\end{array}$ & 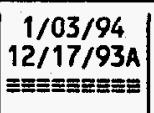 & $\mid \begin{array}{c}1 / 31 / 94 \\
1 / 18 / 94 \mathrm{~A} \\
0= \pm=1\end{array}$ & $\begin{array}{c}2 / 14 / 94 \\
3 / 18 / 94 \mathrm{~A} \\
\equiv \equiv \equiv \equiv \pm \equiv \equiv\end{array}$ & $\begin{array}{c}2 / 28 / 94 \\
4 / 29 / 94 \mathrm{~A} \\
= \pm=\mid\end{array}$ & $\mid \begin{array}{l}3 / 14 / 94 \\
5 / 27 / 94 \mathrm{~A} \\
\end{array}$ & $\begin{array}{c}5 / 09 / 94 \\
7 / 15 / 94 \mathrm{~A} \\
\equiv=0\end{array}$ & $\begin{array}{l}8 / 29 / 94 \\
2 / 16 / 95\end{array}$ & $\begin{array}{l}9 / 12 / 94 \\
2 / 23 / 95\end{array}$ & $\begin{array}{r}8 / 07 / 95 \\
8 / 07 / 95 \\
24\end{array}$ \\
\hline $\begin{array}{l}\text { FL } 0255 \\
\text { Sorbent Surge Hopper Filter }\end{array}$ & 104 & PP-8 & $\begin{array}{r}P \\
A / F\end{array}$ & 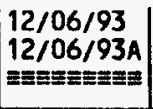 & $\begin{array}{l}12 / 20 / 93 \\
12 / 13 / 93 \mathrm{~A} \\
\mid= \pm=1\end{array}$ & \begin{tabular}{|c|}
$1 / 03 / 94$ \\
$12 / 17 / 93 \mathrm{~A}$ \\
$= \pm$
\end{tabular} & $\begin{array}{l}1 / 31 / 94 \\
1 / 18 / 94 \mathrm{~A} \\
\end{array}$ & $\mid \begin{array}{c}2 / 14 / 94 \\
3 / 18 / 94 \mathrm{~A} \\
\equiv \equiv \pm \equiv \pm= \pm \pm=\end{array}$ & $\begin{array}{c}2 / 28 / 94 \\
4 / 29 / 94 \mathrm{~A} \\
\equiv=\equiv= \pm\end{array}$ & $\left|\begin{array}{c}3 / 14 / 94 \\
5 / 27 / 94 \mathrm{~A} \\
2\end{array}\right|$ & $\begin{array}{c}5 / 09 / 94 \\
7 / 15 / 94 A \\
\end{array}$ & $\begin{array}{l}8 / 29 / 94 \\
2 / 16 / 95\end{array}$ & $\begin{array}{l}9 / 12 / 94 \\
2 / 23 / 95\end{array}$ & $\begin{array}{r}5 / 30 / 95 \\
5 / 30 / 95 \\
14\end{array}$ \\
\hline $\begin{array}{lc}\text { VL0258 } & 1 \\
\text { Baghouse Bottoms Valve } \\
\text { Deleted }\end{array}$ & & & $\begin{array}{r}P \\
A / F\end{array}$ & & & & & & & & & & & 0 \\
\hline $\begin{array}{l}\text { VL0259 } \\
\text { Coal Diverter Valve }\end{array}$ & 107 & PP-5 & $\begin{array}{r}P \\
A / F\end{array}$ & $\mid \begin{array}{l}12 / 06 / 93 \\
12 / 06 / 93 \mathrm{~A} \\
\pm= \pm= \pm\end{array}$ & $\mid \begin{array}{l}12 / 20 / 93 \\
12 / 13 / 93 \mathrm{~A} \\
\equiv \equiv \pm \equiv \mathrm{I}\end{array}$ & $\left|\begin{array}{c}1 / 03 / 94 \\
12 / 17 / 93 \mathrm{~A} \\
= \pm= \pm \equiv=\mid\end{array}\right|$ & $\begin{array}{l}1 / 31 / 94 \\
1 / 17 / 94 \mathrm{~A} \\
\equiv=\equiv\end{array}$ & 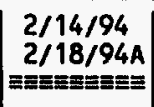 & $\begin{array}{c}2 / 28 / 94 \\
4 / 29 / 94 \mathrm{~A} \\
= \pm= \pm\end{array}$ & $\begin{array}{l}3 / 14 / 94 \\
5 / 27 / 94 \mathrm{~A} \\
==0\end{array}$ & $\begin{array}{c}5 / 09 / 94 \\
6 / 24 / 94 \mathrm{~A} \\
\end{array}$ & $\begin{array}{l}9 / 26 / 94 \\
1 / 15 / 95\end{array}$ & $\begin{array}{r}10 / 10 / 94 \\
1 / 22 / 95\end{array}$ & $\begin{array}{r}1 / 03 / 95 \\
1 / 03 / 95 \\
-3\end{array}$ \\
\hline $\begin{array}{l}\text { VL0260 } \\
\text { Dry Coal Diverter Valve }\end{array}$ & 107 & PP-5 & $\begin{aligned} P \\
A / F\end{aligned}$ & $\begin{array}{l}12 / 06 / 93 \\
12 / 06 / 93 \mathrm{~A} \\
\equiv \equiv \equiv= \pm= \pm\end{array}$ & $\begin{array}{l}12 / 20 / 93 \\
12 / 13 / 93 \mathrm{~A} \\
\equiv= \pm= \pm==0\end{array}$ & $\begin{array}{c}1 / 03 / 94 \\
12 / 17 / 93 \mathrm{~A} \\
= \pm \pm= \pm= \pm= \pm\end{array}$ & $\begin{array}{l}1 / 31 / 94 \\
1 / 17 / 94 \mathrm{~A} \\
= \pm= \pm=\end{array}$ & 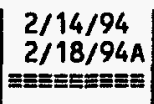 & $\mid$\begin{tabular}{c|}
$2 / 28 / 94$ \\
$4 / 29 / 94 \mathrm{~A}$ \\
$\equiv \mathbf{z}$
\end{tabular} & $\mid \begin{array}{c}3 / 14 / 94 \\
5 / 27 / 94 \mathrm{~A} \\
\equiv \equiv \equiv=\equiv=E\end{array}$ & $\begin{array}{l}5 / 09 / 94 \\
6 / 24 / 94 \mathrm{~A} \\
= \pm= \pm= \pm=\end{array}$ & $\begin{array}{l}9 / 26 / 94 \\
1 / 15 / 95\end{array}$ & $\begin{array}{r}10 / 10 / 94 \\
1 / 22 / 95\end{array}$ & $\begin{array}{r}1 / 03 / 95 \\
1 / 03 / 95 \\
-3\end{array}$ \\
\hline
\end{tabular}

EQUIPMENT LIST CLASS: MECHANICAL - MATERIAL. HANDLING

\begin{tabular}{|c|c|c|c|c|c|c|c|c|c|c|c|c|c|c|c|c|c|}
\hline $\begin{array}{l}\text { FD0251 } \\
\text { Sorbent }\end{array}$ & Feeder & 1 & 1361E & 110 & PP-10 & $\begin{array}{r}P \\
A / F\end{array}$ & $\mid \begin{array}{l}12 / 17 / 93 \\
12 / 17 / 94 \mathrm{~A} \\
\equiv \pm \equiv \equiv \equiv \equiv \equiv \equiv\end{array}$ & $\left|\begin{array}{c}12 / 31 / 93 \\
1 / 06 / 94 \mathrm{~A} \\
0=0\end{array}\right|$ & 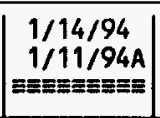 & $\begin{array}{l}2 / 11 / 94 \\
2 / 11 / 94 \mathrm{~A} \\
\end{array}$ & \begin{tabular}{|}
$2 / 25 / 94$ \\
$4 / 15 / 94 \mathrm{~A}$ \\
\end{tabular} & \begin{tabular}{|l|}
$3 / 11 / 94$ \\
$4 / 29 / 94 \mathrm{~A}$ \\
\end{tabular} & \begin{tabular}{|c|}
$3 / 25 / 94$ \\
$7 / 22 / 94 \mathrm{~A}$ \\
$\equiv \geq \equiv \equiv \equiv=\equiv$
\end{tabular} & 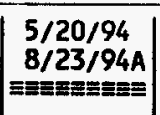 & $\begin{array}{r}10 / 14 / 94 \\
4 / 21 / 95\end{array}$ & $\begin{array}{r}10 / 28 / 94 \\
4 / 28 / 95\end{array}$ & $\begin{array}{r}3 / 30 / 95 \\
3 / 30 / 95 \\
-4\end{array}$ \\
\hline $\begin{array}{l}\text { FD0252 } \\
\text { Carbonizer }\end{array}$ & Coal & $\begin{array}{c}1 \\
\text { feeder }\end{array}$ & $1361 \mathrm{E}$ & 110 & $P P-10$ & $\begin{array}{r}P \\
A / F\end{array}$ & 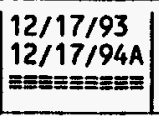 & $\left|\begin{array}{c}12 / 31 / 93 \\
1 / 06 / 94 \mathrm{~A} \\
\mid=1\end{array}\right|$ & $\left|\begin{array}{c}1 / 14 / 94 \\
1 / 11 / 94 \mathrm{~A} \\
\equiv\end{array}\right|$ & $\begin{array}{c}2 / 11 / 94 \\
2 / 11 / 94 \mathrm{~A} \\
2 / 119\end{array}$ & 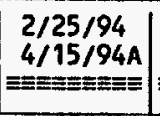 & $\begin{array}{c}3 / 11 / 94 \\
4 / 29 / 94 \mathrm{~A} \\
\end{array}$ & $\begin{array}{l}3 / 25 / 94 \\
7 / 22 / 94 \mathrm{~A} \\
\end{array}$ & $\mid \begin{array}{c}5 / 20 / 94 \\
8 / 23 / 94 \mathrm{~A} \\
20\end{array}$ & $\begin{array}{r}10 / 14 / 94 \\
4 / 21 / 95\end{array}$ & $\begin{array}{r}10 / 28 / 94 \\
4 / 28 / 95\end{array}$ & $\begin{array}{r}3 / 30 / 95 \\
3 / 30 / 95 \\
-4\end{array}$ \\
\hline $\begin{array}{l}\text { FD0253 } \\
\text { Combustor }\end{array}$ & Coal & $\begin{array}{c}1 \\
\text { Feeder }\end{array}$ & $1361 \mathrm{E}$ & 110 & PP-10 & $\begin{array}{r}P \\
A / F\end{array}$ & $\mid \begin{array}{l}12 / 17 / 93 \\
12 / 17 / 93 \mathrm{~A} \\
\equiv \equiv \equiv=\equiv \equiv \equiv \equiv \equiv \mid\end{array}$ & $\left|\begin{array}{c}12 / 31 / 93 \\
1 / 10 / 94 \mathrm{~A} \\
=\equiv=\equiv= \pm=\equiv\end{array}\right|$ & $\left|\begin{array}{c}1 / 14 / 94 \\
1 / 11 / 94 \mathrm{~A} \\
=\equiv= \pm= \pm=\equiv\end{array}\right|$ & \begin{tabular}{|l|}
$2 / 11 / 94$ \\
$2 / 11 / 94 \mathrm{~A}$ \\
\end{tabular} & $\begin{array}{l}2 / 25 / 94 \\
4 / 15 / 94 \mathrm{~A} \\
\end{array}$ & \begin{tabular}{|l|}
$3 / 11 / 94$ \\
$4 / 29 / 94 \mathrm{~A}$ \\
$= \pm=\equiv=\equiv$
\end{tabular} & 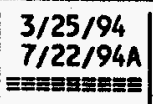 & $\begin{array}{l}5 / 20 / 94 \\
8 / 23 / 94 \mathrm{~A} \\
\end{array}$ & $\begin{array}{r}10 / 14 / 94 \\
4 / 21 / 95\end{array}$ & $\begin{array}{r}10 / 28 / 94 \\
4 / 28 / 95\end{array}$ & $\begin{array}{r}3 / 30 / 95 \\
3 / 30 / 95 \\
-4\end{array}$ \\
\hline
\end{tabular}


COMPONENT SCHEDULE

EQUIPMENT LIST REVISION DATED - $7 / 19 / 94$
FOSTER WHEELER USA CORP REPOTT SCSOCT File SCSCS R2D

-04160 1/09/95 Actuals thru: 30-Dec-94

\begin{tabular}{|c|c|c|c|c|c|c|c|c|c|c|c|c|c|c|c|c|}
\hline $\begin{array}{l}\text { ITEM } \\
\text { ITEM DESC } \\
\text { Comment }\end{array}$ & QTY & SPEC/REQ & INQ \# & PO \# & & $\begin{array}{c}\text { FW } \\
\text { ISSUE } \\
\text { SPEC/ } \\
\text { REQ }\end{array}$ & $\begin{array}{l}\text { SCS } \\
\text { APPROVE } \\
\text { SPEC/ } \\
\text { REQ }\end{array}$ & $\begin{array}{c}\text { FW } \\
\text { ISSUE } \\
\text { INOUIRY/ } \\
\text { RFQ }\end{array}$ & $\begin{array}{c}\text { FW } \\
\text { RECEIVE } \\
\text { BIDS/ } \\
\text { QUOTES }\end{array}$ & $\begin{array}{c}\text { FW } \\
\text { COMPLETE } \\
\text { BID } \\
\text { TABS }\end{array}$ & $\begin{array}{c}\text { SCS } \\
\text { BID } \\
\text { TAB } \\
\text { APPROVAL. }\end{array}$ & $\begin{array}{c}\text { FW } \\
\text { RELEASE } \\
\text { PURCHASE } \\
\text { ORDER }\end{array}$ & $\begin{array}{c}\text { FH } \\
\text { RECE IVE } \\
\text { VENDOR } \\
\text { DRAWINGS }\end{array}$ & $\begin{array}{l}\text { SHIP } \\
\text { F.O.B. }\end{array}$ & $\begin{array}{c}\text { DEL IVERY } \\
\text { TO } \\
\text { SITE/SHOP }\end{array}$ & $\begin{array}{l}\text { FIELD } \\
\text { NEED } \\
\text { SLACK } \\
\text { (IN WKS) }\end{array}$ \\
\hline $\begin{array}{l}\text { FD0256 } \\
\text { Fines Cool ing }\end{array}$ & $\begin{array}{r}1 \\
\text { Screw }\end{array}$ & $\begin{array}{l}\text { 1379B } \\
\text { Feeder }\end{array}$ & 100 & PP- 13 & $\begin{array}{r}P \\
A / F\end{array}$ & $\begin{array}{l}12 / 17 / 93 \\
12 / 17 / 93 \mathrm{~A} \\
\equiv \pm \equiv \equiv=\end{array}$ & $\mid \begin{array}{l}12 / 31 / 93 \\
12 / 23 / 93 \mathrm{~A} \\
\mid \mathrm{z}\end{array}$ & $\begin{array}{c}1 / 14 / 94 \\
12 / 24 / 93 \mathrm{~A} \\
\equiv=\equiv\end{array}$ & 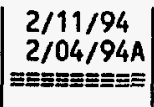 & $\begin{array}{l}2 / 25 / 94 \\
4 / 01 / 94 \mathrm{~A} \\
=\end{array}$ & $\begin{array}{c}3 / 11 / 94 \\
4 / 29 / 94 \mathrm{~A} \\
\equiv\end{array}$ & $\begin{array}{l}3 / 25 / 94 \\
9 / 14 / 94 \mathrm{~A} \\
\end{array}$ & $\left|\begin{array}{c}5 / 20 / 94 \\
11 / 15 / 94 \mathrm{~A} \\
0=0\end{array}\right|$ & $\begin{array}{r}10 / 13 / 94 \\
5 / 20 / 95\end{array}$ & $\begin{array}{r}10 / 27 / 94 \\
5 / 27 / 95\end{array}$ & $\begin{array}{r}5 / 08 / 95 \\
5 / 08 / 95 \\
-3\end{array}$ \\
\hline
\end{tabular}

EQUIPMENT LIST CLASS: MECHANICAL - WESTINGHOUSE

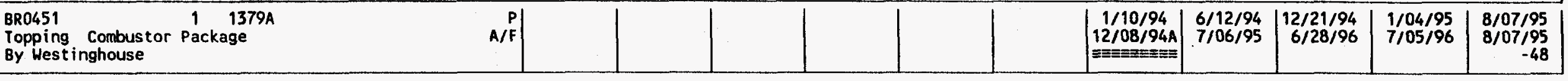

EQUIPMENT LIST CLASS: MECHANICAL EQUIPMENT

\begin{tabular}{|c|c|c|c|c|c|c|c|c|c|c|c|c|c|c|c|c|}
\hline $\begin{array}{l}\text { BL0251 } \\
\text { Baghouse Fan } \\
\text { Deleted }\end{array}$ & 1 & & & & $\begin{array}{r}P \\
A / F\end{array}$ & & & & & & & & & & & 0 \\
\hline $\begin{array}{l}\text { Co0251 } \\
\text { Booster Air Compress }\end{array}$ & $\begin{array}{c}1 \\
\text { sor }\end{array}$ & $1322 A$ & 114 & PP-6 & $\begin{array}{r}P \\
A / F\end{array}$ & $\begin{array}{c}1 / 03 / 94 \\
1 / 25 / 94 \mathrm{~A} \\
\pm \equiv \equiv \equiv= \pm\end{array}$ & $\mid \begin{array}{c}1 / 17 / 94 \\
1 / 28 / 94 \mathrm{~A} \\
\equiv= \pm= \pm= \pm \equiv \equiv\end{array}$ & $\begin{array}{c}1 / 31 / 94 \\
1 / 28 / 94 \mathrm{~A} \\
\equiv \equiv \equiv \equiv \equiv \pm \equiv\end{array}$ & $\mid \begin{array}{c}2 / 28 / 94 \\
2 / 25 / 94 A \\
0= \pm\end{array}$ & $\mid \begin{array}{c}3 / 14 / 94 \\
4 / 15 / 94 \mathrm{~A} \\
\equiv \equiv \pm \equiv \equiv \equiv \equiv \equiv\end{array}$ & $\mid \begin{array}{c}3 / 28 / 94 \\
4 / 29 / 94 \mathrm{~A} \\
== \pm=\end{array}$ & $\left|\begin{array}{c}4 / 11 / 94 \\
6 / 28 / 94 \mathrm{~A} \\
0\end{array}\right|$ & 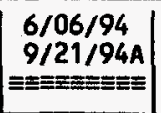 & $\begin{array}{l}1 / 27 / 95 \\
6 / 02 / 95\end{array}$ & $\begin{array}{l}2 / 10 / 95 \\
6 / 09 / 95\end{array}$ & $\begin{array}{r}5 / 08 / 95 \\
5 / 08 / 95 \\
-5\end{array}$ \\
\hline $\begin{array}{l}\text { CO0252 } \\
\text { Transport Air Compre }\end{array}$ & $\begin{array}{l}1 \\
\text { essor }\end{array}$ & $r^{1322 B}$ & 114 & PP-6 & $\begin{array}{r}P \\
A / F\end{array}$ & 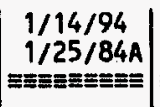 & $\left|\begin{array}{c}1 / 28 / 94 \\
1 / 28 / 94 \mathrm{~A} \\
= \pm\end{array}\right|$ & $\begin{array}{c}2 / 11 / 94 \\
1 / 28 / 94 \mathrm{~A} \\
\equiv \equiv \equiv \equiv \equiv \equiv \equiv=\mid\end{array}$ & $\mid \begin{array}{c}3 / 11 / 94 \\
2 / 25 / 94 \mathrm{~A} \\
20\end{array}$ & $\begin{array}{l}3 / 25 / 94 \\
4 / 15 / 94 \mathrm{~A} \\
= \pm \equiv \equiv\end{array}$ & $\mid \begin{array}{c}4 / 08 / 94 \\
4 / 29 / 94 \mathrm{~A} \\
\equiv \pm \equiv= \pm=\mid\end{array}$ & $\left|\begin{array}{c}4 / 22 / 94 \\
6 / 28 / 94 \mathrm{~A} \\
6\end{array}\right|$ & $\mid \begin{array}{c}6 / 17 / 94 \\
9 / 21 / 94 \mathrm{~A} \\
0=0\end{array}$ & $\begin{array}{l}1 / 03 / 95 \\
6 / 02 / 95\end{array}$ & $\begin{array}{l}1 / 17 / 95 \\
6 / 09 / 95\end{array}$ & $\begin{array}{r}2 / 16 / 95 \\
2 / 16 / 95 \\
-16\end{array}$ \\
\hline $\begin{array}{l}\text { FNO251 } \\
\text { Char Cooler Fan }\end{array}$ & 1 & 13258 & 119 & PP- 15 & $\begin{array}{r}P \\
A / F\end{array}$ & 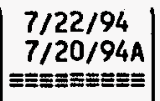 & 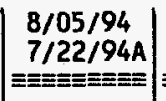 & $\begin{array}{l}8 / 12 / 94 \\
7 / 29 / 94 \mathrm{~A} \\
=\equiv \equiv \equiv\end{array}$ & 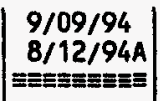 & $\mid \begin{array}{c}9 / 23 / 94 \\
9 / 09 / 94 \mathrm{~A} \\
\equiv \equiv \equiv=\equiv=\equiv\end{array}$ & $\left|\begin{array}{c}10 / 07 / 94 \\
9 / 16 / 94 \mathrm{~A} \\
\equiv=\equiv\end{array}\right|$ & $\mid \begin{array}{c}10 / 21 / 94 \\
9 / 23 / 94 \mathrm{~A} \\
0=\end{array}$ & 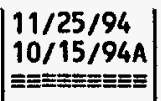 & $\begin{array}{l}4 / 10 / 95 \\
1 / 18 / 95\end{array}$ & $\begin{array}{l}4 / 24 / 95 \\
1 / 25 / 95\end{array}$ & $\begin{array}{r}2 / 13 / 95 \\
2 / 13 / 95 \\
3\end{array}$ \\
\hline
\end{tabular}

EQUIPMENT LIST CLASS: MISCELLANEOUS

\begin{tabular}{|c|c|c|c|c|c|c|c|c|c|c|c|c|c|c|c|c|c|}
\hline $\begin{array}{l}\text { AH0252 } \\
\text { Carbonizer }\end{array}$ & Air Prehe & $\begin{array}{c}1 \\
\text { eater }\end{array}$ & $r^{1244 A}$ & 105 & $P P-4$ & $\begin{array}{r}P \\
A / F\end{array}$ & \begin{tabular}{|l|}
$12 / 06 / 93$ \\
$12 / 06 / 93 \mathrm{~A}$ \\
$\equiv \equiv \equiv \equiv \equiv \equiv \equiv \equiv \equiv$
\end{tabular} & $\mid \begin{array}{l}12 / 20 / 93 \\
12 / 09 / 94 \mathrm{~A} \\
\equiv=\equiv \equiv=\equiv\end{array}$ & $\left|\begin{array}{c}1 / 03 / 94 \\
12 / 17 / 93 \mathrm{~A} \\
\equiv=E= \pm \equiv \equiv \equiv\end{array}\right|$ & $\left|\begin{array}{c}1 / 31 / 94 \\
1 / 17 / 94 \mathrm{~A} \\
\vdots \equiv \equiv \equiv \equiv \equiv \equiv \equiv \equiv \equiv\end{array}\right|$ & $\mid \begin{array}{l}2 / 14 / 94 \\
2 / 25 / 94 \mathrm{~A} \\
=\equiv \equiv \equiv\end{array}$ & $\begin{array}{c}2 / 28 / 94 \\
4 / 29 / 94 \mathrm{~A} \\
\equiv=\equiv \equiv \equiv \equiv \equiv \equiv\end{array}$ & $\mid \begin{array}{c}3 / 14 / 94 \\
5 / 27 / 94 \mathrm{~A} \\
5 \mid\end{array}$ & $\mid \begin{array}{c}5 / 09 / 94 \\
7 / 22 / 94 \mathrm{~A} \\
\equiv \equiv \equiv=\equiv \equiv\end{array}$ & $\mid \begin{array}{r}10 / 03 / 94 \\
3 / 30 / 95\end{array}$ & $\left|\begin{array}{r}10 / 17 / 94 \\
4 / 06 / 95\end{array}\right|$ & $\begin{array}{r}5 / 30 / 95 \\
5 / 30 / 95 \\
8\end{array}$ \\
\hline $\begin{array}{l}\text { AHO253 } \\
\text { Combustor }\end{array}$ & Air Prehea & $\begin{array}{l}1 \\
\text { ter }\end{array}$ & 12448 & 105 & $P P-4$ & $\begin{array}{r}P \\
A / F\end{array}$ & $\begin{array}{l}12 / 06 / 93 \\
12 / 06 / 93 \mathrm{~A} \\
0= \pm \equiv \equiv \equiv\end{array}$ & 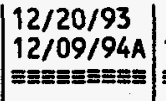 & $\begin{array}{c}1 / 03 / 94 \\
12 / 17 / 93 \mathrm{~A} \\
0\end{array}$ & $\mid \begin{array}{l}1 / 31 / 94 \\
1 / 17 / 94 \mathrm{~A} \\
=\end{array}$ & $\left|\begin{array}{c}2 / 14 / 94 \\
2 / 25 / 94 \mathrm{~A} \\
\end{array}\right|$ & 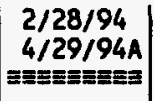 & $\mid \begin{array}{c}3 / 14 / 94 \\
5 / 27 / 94 \mathrm{~A} \\
\end{array}$ & $\mid \begin{array}{l}5 / 09 / 94 \\
7 / 22 / 94 \mathrm{~A} \\
\end{array}$ & $\left|\begin{array}{r}10 / 03 / 94 \\
3 / 30 / 95\end{array}\right|$ & $\left|\begin{array}{r}10 / 17 / 94 \\
4 / 06 / 95\end{array}\right|$ & $\begin{array}{r}12 / 14 / 94 \\
12 / 14 / 94 \\
-16\end{array}$ \\
\hline $\begin{array}{l}\text { AH0254 } \\
\text { Combus tor }\end{array}$ & Above Grid & ${ }^{1} \mathrm{Air}$ & $\begin{array}{l}1244 \mathrm{C} \\
\text { r Preheate }\end{array}$ & $r^{105}$ & PP-4 & $\begin{array}{r}P \\
A / F\end{array}$ & $\begin{array}{l}12 / 06 / 93 \\
12 / 06 / 93 \mathrm{~A} \\
= \pm \pm \equiv \equiv=\equiv \equiv \equiv\end{array}$ & $\mid \begin{array}{l}12 / 20 / 93 \\
12 / 09 / 94 \mathrm{~A} \\
\equiv \equiv \equiv \equiv \equiv \equiv \equiv \equiv \equiv\end{array}$ & $\begin{array}{c}1 / 03 / 94 \\
12 / 17 / 93 \mathrm{~A} \\
\equiv \equiv= \pm=\equiv \equiv \equiv \equiv\end{array}$ & $\left|\begin{array}{c}1 / 31 / 94 \\
1 / 17 / 94 \mathrm{~A} \\
= \pm \equiv \pm=\equiv \pm \equiv\end{array}\right|$ & $\left|\begin{array}{c}2 / 14 / 94 \\
2 / 25 / 94 \mathrm{~A} \\
\equiv \equiv \equiv= \pm \equiv \equiv\end{array}\right|$ & 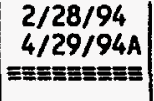 & $\mid \begin{array}{l}3 / 14 / 94 \\
5 / 27 / 94 \mathrm{~A} \\
5 / 27 / 9\end{array}$ & $\mid \begin{array}{l}5 / 09 / 94 \\
7 / 22 / 94 \mathrm{~A} \\
\equiv=\equiv \equiv= \pm \equiv=\equiv\end{array}$ & $\begin{array}{r}10 / 03 / 94 \\
3 / 30 / 95\end{array}$ & $\begin{array}{r}10 / 17 / 94 \\
4 / 06 / 95\end{array}$ & $\begin{array}{r}5 / 08 / 95 \\
5 / 08 / 95 \\
5\end{array}$ \\
\hline $\begin{array}{l}\text { BR0251 } \\
\text { Flare }\end{array}$ & & 1 & $1928 \mathrm{~A}$ & 101 & PP-7 & $\begin{array}{r}P \\
A / F\end{array}$ & 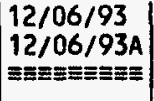 & 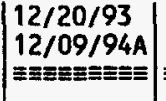 & 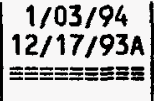 & 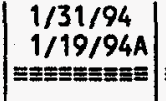 & $\left|\begin{array}{c}2 / 14 / 94 \\
2 / 25 / 94 \mathrm{~A} \\
\equiv \equiv \equiv \equiv \equiv \equiv \equiv \equiv \equiv \mid\end{array}\right|$ & \begin{tabular}{|c|}
$2 / 28 / 94$ \\
$4 / 29 / 94 \mathrm{~A}$ \\
$\equiv \equiv \equiv \equiv \equiv \equiv \equiv \equiv$
\end{tabular} & 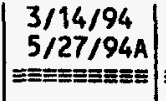 & $\mid \begin{array}{c}5 / 09 / 94 \\
7 / 08 / 94 A \\
\equiv=1\end{array}$ & $\begin{array}{l}11 / 08 / 94 \\
10 / 24 / 94 \mathrm{~A} \\
\end{array}$ & $\left|\begin{array}{l}11 / 22 / 94 \\
10 / 28 / 94 A \\
= \pm \equiv=\end{array}\right|$ & $\begin{array}{r}8 / 07 / 95 \\
8 / 07 / 95 \\
40\end{array}$ \\
\hline
\end{tabular}


COMPONENT SCHEDULE

EQUIPMENT LIST REVISION DATED - $7 / 19 / 94$
FOSTER WHEELER USA CORP REPOrT SCSOCT FWUSA Project 115-00-04160

\begin{tabular}{|c|c|c|c|c|c|c|c|c|c|c|c|c|c|c|c|c|}
\hline $\begin{array}{l}\text { ITEM } \\
\text { ITEM DESC } \\
\text { Comment }\end{array}$ & arr & SPEC/REQ & INO \# & PO \# & & $\begin{array}{c}\text { FW } \\
\text { ISSUE } \\
\text { SPEC/ } \\
\text { REQ }\end{array}$ & $\begin{array}{l}\text { SCS } \\
\text { APPROVE } \\
\text { SPEC/ } \\
\text { REQ }\end{array}$ & $\begin{array}{c}\text { FW } \\
\text { ISSUE } \\
\text { INQUIRY } \\
\text { RFQ }\end{array}$ & $\begin{array}{c}\text { FW } \\
\text { RECEIVE } \\
\text { BIDS/ } \\
\text { QUOTES }\end{array}$ & $\begin{array}{l}\text { FW } \\
\text { COMPLETE } \\
\text { BID } \\
\text { TABS }\end{array}$ & $\begin{array}{c}\text { SCS } \\
\text { BID } \\
\text { TAB } \\
\text { APPROVAL }\end{array}$ & $\begin{array}{c}\text { FW } \\
\text { RELEASE } \\
\text { PURCHASE } \\
\text { ORDER }\end{array}$ & $\begin{array}{c}\text { FW } \\
\text { RECEIVE } \\
\text { VENDOR } \\
\text { DRAWINGS }\end{array}$ & $\begin{array}{l}\text { SHIP } \\
\text { F.O.B. }\end{array}$ & $\begin{array}{c}\text { DEL. IVERY } \\
\text { TO } \\
\text { SITE/SHOP }\end{array}$ & $\begin{array}{l}\text { FIELD } \\
\text { NEED } \\
\text { SLACK } \\
\text { (IN WKS) }\end{array}$ \\
\hline $\begin{array}{l}\text { cro251 } \\
\text { Carbonizer }\end{array}$ & Cyclone & $1353 \mathrm{~A}$ & 100 & PP-1 & $\begin{array}{r}P \\
A / F\end{array}$ & 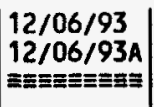 & $\mid \begin{array}{l}12 / 20 / 93 \\
12 / 09 / 94 \mathrm{~A} \\
= \pm= \pm \equiv \pm= \pm=\end{array}$ & $\mid \begin{array}{c}1 / 03 / 94 \\
12 / 17 / 93 \mathrm{~A} \\
\mid= \pm\end{array}$ & $\begin{array}{c}1 / 31 / 94 \\
1 / 18 / 94 \mathrm{~A} \\
0=\end{array}$ & $\mid \begin{array}{c}2 / 14 / 94 \\
2 / 11 / 94 \mathrm{~A} \\
\equiv \equiv= \pm \equiv \equiv \equiv \equiv\end{array}$ & 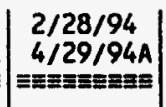 & $\left|\begin{array}{c}3 / 14 / 94 \\
5 / 27 / 94 \mathrm{~A} \\
\equiv\end{array}\right|$ & $\begin{array}{c}5 / 09 / 94 \\
6 / 13 / 94 \mathrm{~A} \\
=\end{array}$ & $\begin{array}{r}11 / 28 / 94 \\
2 / 20 / 95\end{array}$ & $\begin{array}{r}12 / 12 / 94 \\
2 / 27 / 95\end{array}$ & $\begin{array}{r}8 / 07 / 95 \\
8 / 07 / 95 \\
23\end{array}$ \\
\hline
\end{tabular}

EQUIPMENT LIST CLASS: PACKAGES

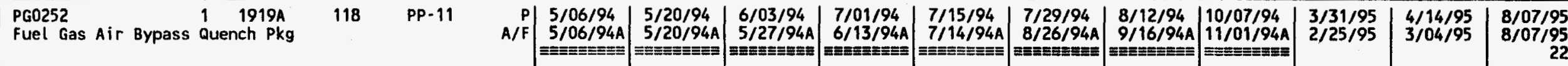

$\begin{array}{ll}\text { PG0253 } & 1 \\ \text { Vitiated Air Bypass Quench Package } \\ \text { deleted }\end{array}$

P/F

deleted

EQUIPMENT LIST CLASS: REFRACTORY LINED PIPE

$\begin{array}{lllll}\text { LP0601 } & 1 & 1161 \mathrm{~A} & 116 & \text { PP-16 }\end{array}$

$\stackrel{1}{\infty}$

\begin{tabular}{|llll}
\hline & $1161 \mathrm{~A}$ & 116 & PP-16
\end{tabular}

\begin{tabular}{l|l|l|l|l|l|}
$P$ & $1 / 21 / 94$ & $2 / 04 / 94$
\end{tabular} F $1 / 21 / 94 \mathrm{~A} \mid 2 / 04 / 94 \mathrm{~A}$

$2 / 18 / 94|3 / 18 / 94|$

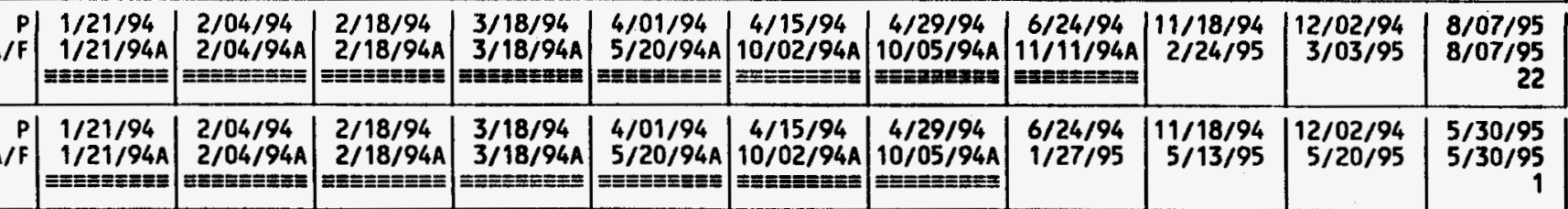

$\begin{array}{lllll}\text { LP0613 } & 1 & 1161 \mathrm{~A} & 116 & \text { PP-16 }\end{array}$

\begin{tabular}{r|l|l|l|l|l|}
$\mathrm{P}$ & $1 / 21 / 94$ & $2 / 04 / 94$ & $2 / 18 / 94$ & $3 / 18 / 94$ \\
\hline
\end{tabular} \begin{tabular}{|l|c|c|c|c|c|c|c|}
$4 / 01 / 94$ & $4 / 15 / 94$ & $4 / 29 / 94$ & $6 / 24 / 94$ & $11 / 18 / 94$ & $12 / 02 / 94$ & $12 / 28 / 94$ \\
\hline 5 & $5 / 20 / 94 A$ & $10 / 02 / 94 A$ & $0 / 05 / 94 A$ & $11 / 11 / 94 A$ & $2 / 24 / 95$ & $3 / 03 / 95$ & $12 / 28 / 94$
\end{tabular}

\begin{tabular}{llllll}
$\begin{array}{l}\text { LP0613 } \\
\text { Carbonizer Char }\end{array}$ & 1 & $1161 \mathrm{~A}$ & 116 & PP - 16 \\
\hline LP0801 & 1 & $1161 \mathrm{~A}$ & 116 & PP- 16
\end{tabular}

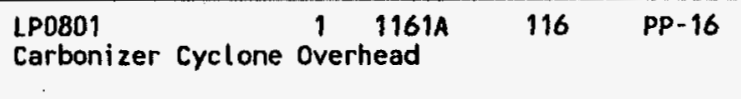

\begin{tabular}{lcccc} 
LP0802 & 1 & $1161 \mathrm{~A}$ & 116 & PP-16 \\
\hline
\end{tabular}

Carbonizer PCD Overhead

A/F

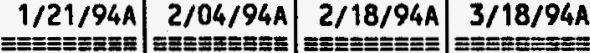

\begin{tabular}{l|l|l|l|l|l|l|}
\hline P & $1 / 21 / 94$ & $2104 / 94$ \\
\hline
\end{tabular}

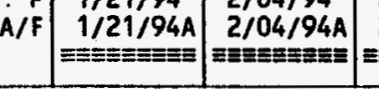
$11 / 11 / 94 \mathrm{~A}$

\begin{tabular}{l|l|l|l|l|l|l|l|l|}
$\mathrm{P}$ & $1 / 21 / 94$ & $2 / 04 / 94$ & $2 / 18 / 94$ & $3 / 18 / 94$ & $4 / 01 / 94$ & $4 / 15 / 94$ & $4 / 29 / 94$
\end{tabular}

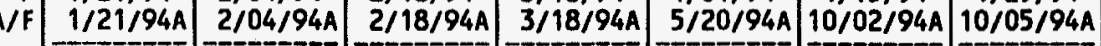

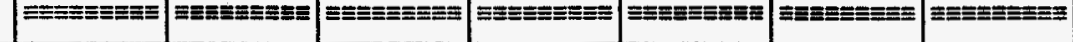

\begin{tabular}{|l|c|c|c|}
\hline $\begin{array}{l}\text { LP0803 } 1161 \mathrm{~A} \\
\text { Carbonizer Cyclone Bottoms }\end{array}$ & 116 & PP-16 & \\
\hline
\end{tabular}

\begin{tabular}{|l|l|l|l|}
\hline $\begin{array}{l}\text { LP0804 } \\
\text { Carbonizer Char to Combustor }\end{array}$ & 11616 & $P P-16$
\end{tabular}

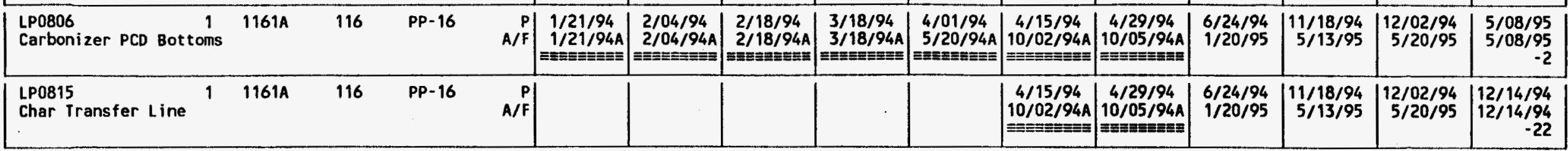




\begin{tabular}{|c|c|c|c|c|c|c|c|c|c|c|c|c|c|c|c|c|}
\hline $\begin{array}{l}\text { IIEM } \\
\text { ITEM DESC } \\
\text { Comment }\end{array}$ & QTY & SPEC/REQ & ING \# & PO \# & & $\begin{array}{c}\text { FW } \\
\text { ISSUE } \\
\text { SPEC/ } \\
\text { REQ }\end{array}$ & $\begin{array}{l}\text { SCS } \\
\text { APPROVE } \\
\text { SPEC/ } \\
\text { REQ }\end{array}$ & $\begin{array}{l}\text { FW } \\
\text { ISSUE } \\
\text { INQUIRY/ } \\
\text { RFQ }\end{array}$ & \begin{tabular}{c|} 
FW \\
RECEIVE \\
BIDS/ \\
QUOTES \\
\end{tabular} & \begin{tabular}{|c} 
FW \\
COMPLETE \\
BID \\
TABS \\
\end{tabular} & \begin{tabular}{|c|} 
SCS \\
BID \\
TAB \\
APPROVAL \\
\end{tabular} & \begin{tabular}{|c} 
FH \\
RELEASE \\
PURCHASE \\
ORDER
\end{tabular} & $\begin{array}{c}\text { FW } \\
\text { RECEIVE } \\
\text { VENDOR } \\
\text { DRAWINGS }\end{array}$ & $\begin{array}{l}\text { SHIP } \\
\text { F.O.B. }\end{array}$ & $\begin{array}{l}\text { DELIVERY } \\
\text { TO } \\
\text { SITE/SHOP }\end{array}$ & $\begin{array}{l}\text { FIELD } \\
\text { NEED } \\
\text { SLACK } \\
\text { (IN WKS ) }\end{array}$ \\
\hline $\begin{array}{l}\text { LP0910 } \\
\text { Combustor Primary Ho }\end{array}$ & $\begin{array}{r}1 \\
\text { Hot }\end{array}$ & $\begin{array}{l}1161 \mathrm{~A} \\
\text { tart-up air }\end{array}$ & $r^{116}$ & PP- 16 & $\begin{array}{r}P \\
A / F\end{array}$ & 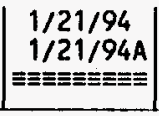 & $\begin{array}{l}2 / 04 / 94 \\
2 / 04 / 94 \mathrm{~A} \\
=\equiv=\equiv\end{array}$ & $\mid \begin{array}{c}2 / 18 / 94 \\
2 / 18 / 94 \mathrm{~A} \\
\equiv= \pm=E=\mid\end{array}$ & $\mid \begin{array}{c}3 / 18 / 94 \\
3 / 18 / 94 \mathrm{~A} \\
\equiv= \pm= \pm= \pm= \pm\end{array}$ & $\begin{array}{l}4 / 01 / 94 \\
5 / 20 / 94 \mathrm{~A} \\
\equiv \equiv \equiv \equiv \equiv \equiv \equiv= \\
\end{array}$ & 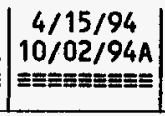 & $\mid \begin{array}{c}4 / 29 / 94 \\
10 / 05 / 94 \mathrm{~A} \\
\equiv \pm \pm= \pm\end{array}$ & $\begin{array}{c}6 / 24 / 94 \\
11 / 11 / 94 \mathrm{~A} \\
\end{array}$ & $\begin{array}{r}11 / 18 / 94 \\
2 / 24 / 95\end{array}$ & $\begin{array}{r}12 / 02 / 94 \\
3 / 03 / 95\end{array}$ & $\begin{array}{r}12 / 14 / 94 \\
12 / 14 / 94 \\
-11\end{array}$ \\
\hline $\begin{array}{l}\text { LP0913 } \\
\text { Combustor Above Gric }\end{array}$ & id ${ }^{1}$ sto & $\begin{array}{l}1161 \mathrm{~A} \\
\text { art-up air }\end{array}$ & 116 & $P P=16$ & $\begin{array}{r}P \\
A / F\end{array}$ & $\mid \begin{array}{c}1 / 21 / 94 \\
1 / 21 / 94 \mathrm{~A} \\
\equiv \equiv \equiv \equiv \pm \equiv \equiv \equiv\end{array}$ & $\mid \begin{array}{c}2 / 04 / 94 \\
2 / 04 / 94 \mathrm{~A} \\
= \pm \equiv= \pm= \pm= \pm\end{array}$ & $\mid \begin{array}{c}2 / 18 / 94 \\
2 / 18 / 94 \mathrm{~A} \\
\equiv \equiv \equiv \equiv=\equiv \equiv\end{array}$ & 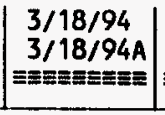 & $\begin{array}{l}4 / 01 / 94 \\
5 / 20 / 94 \mathrm{~A} \\
\equiv \equiv=\equiv\end{array}$ & $\left|\begin{array}{c}4 / 15 / 94 \\
10 / 02 / 94 \mathrm{~A} \\
\equiv / 02 / 9\end{array}\right|$ & 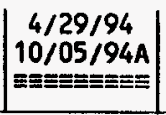 & $\begin{array}{l}6 / 24 / 94 \\
1 / 06 / 95\end{array}$ & $\begin{array}{r}11 / 18 / 94 \\
3 / 24 / 95\end{array}$ & $\begin{array}{r}12 / 02 / 94 \\
3 / 31 / 95\end{array}$ & $\begin{array}{r}5 / 08 / 95 \\
5 / 08 / 95 \\
5\end{array}$ \\
\hline $\begin{array}{l}\text { LP1001 } \\
\text { Combustor Cyclone ov }\end{array}$ & $\begin{array}{c}1 \\
\text { Overhe }\end{array}$ & $1161 \mathrm{~A}$ & 116 & PP- 16 & $\begin{array}{r}P \\
A / F\end{array}$ & 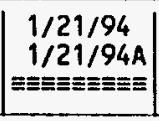 & 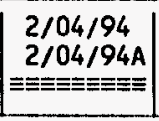 & $\mid \begin{array}{c}2 / 18 / 94 \\
2 / 18 / 94 \mathrm{~A} \\
\equiv \equiv \equiv \equiv \equiv \equiv \equiv \equiv\end{array}$ & 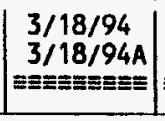 & $\begin{array}{c}4 / 01 / 94 \\
5 / 20 / 94 \mathrm{~A} \\
\equiv \equiv \equiv \equiv \equiv \equiv \equiv \equiv\end{array}$ & $\begin{array}{c}4 / 15 / 94 \\
10 / 02 / 94 \mathrm{~A} \\
0202\end{array}$ & 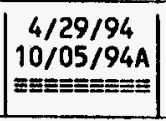 & $\begin{array}{l}6 / 24 / 94 \\
2 / 10 / 95\end{array}$ & $\begin{array}{r}11 / 18 / 94 \\
6 / 02 / 95\end{array}$ & $\begin{array}{r}12 / 02 / 94 \\
6 / 09 / 95\end{array}$ & $\begin{array}{r}8 / 07 / 95 \\
8 / 07 / 95 \\
8\end{array}$ \\
\hline $\begin{array}{l}\text { LP1002 } \\
\text { Combustor PCD Overhe }\end{array}$ & $\stackrel{1}{1}$ & $1161 \mathrm{~A}$ & 116 & PP-16 & $\begin{array}{r}P \\
A / F\end{array}$ & $\mid \begin{array}{c}1 / 21 / 94 \\
1 / 21 / 94 \mathrm{~A} \\
\equiv= \pm= \pm\end{array}$ & 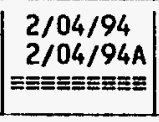 & 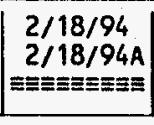 & 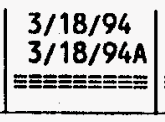 & $\mid \begin{array}{c}4 / 01 / 94 \\
5 / 20 / 94 \mathrm{~A} \\
= \pm \equiv \equiv \equiv \equiv \equiv \equiv\end{array}$ & $\mid \begin{array}{c}4 / 15 / 94 \\
10 / 02 / 94 \mathrm{~A} \\
\equiv= \pm E \equiv \pm E \equiv \equiv\end{array}$ & $\mid \begin{array}{c}4 / 29 / 94 \\
10 / 05 / 94 \mathrm{~A} \\
\equiv= \pm\end{array}$ & $\begin{array}{l}6 / 24 / 94 \\
2 / 10 / 95\end{array}$ & $\begin{array}{r}11 / 18 / 94 \\
6 / 02 / 95\end{array}$ & $\begin{array}{r}12 / 02 / 94 \\
6 / 09 / 95\end{array}$ & $\begin{array}{r}5 / 08 / 95 \\
5 / 08 / 95 \\
-5 \\
\end{array}$ \\
\hline $\begin{array}{l}\text { LP1004 } \\
\text { Combustor PCD Botton }\end{array}$ & $\begin{array}{r}1 \\
\text { oms }\end{array}$ & $1161 \mathrm{~A}$ & 116 & PP- 16 & $\begin{array}{r}P \\
A / F\end{array}$ & $\mid \begin{array}{c}1 / 21 / 94 \\
1 / 21 / 94 \mathrm{~A} \\
\equiv \equiv \equiv \equiv \equiv \equiv=\mid\end{array}$ & 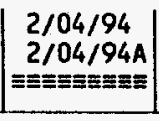 & $\begin{array}{c}2 / 18 / 94 \\
2 / 18 / 94 \mathrm{~A} \\
\equiv= \pm= \pm=\equiv\end{array}$ & 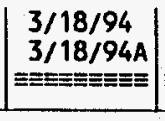 & $\begin{array}{c}4 / 01 / 94 \\
5 / 20 / 94 \mathrm{~A} \\
= \pm=E=E\end{array}$ & $\left|\begin{array}{c}4 / 15 / 94 \\
10 / 02 / 94 A \\
\equiv \equiv E \equiv \equiv \equiv \equiv \equiv \equiv\end{array}\right|$ & 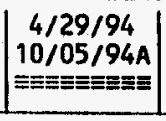 & $\begin{array}{l}6 / 24 / 94 \\
2 / 10 / 95\end{array}$ & $\begin{array}{r}11 / 18 / 94 \\
6 / 02 / 95\end{array}$ & $\begin{array}{r}12 / 02 / 94 \\
6 / 09 / 95\end{array}$ & $\begin{array}{r}7 / 12 / 95 \\
7 / 12 / 95 \\
5\end{array}$ \\
\hline $\begin{array}{l}\text { LP1334 } \\
\text { Air Preheater Line }\end{array}$ & 1 & $1161 \mathrm{~A}$ & 116 & PP- 16 & $A / F$ & & & & & & 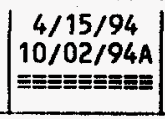 & $\left|\begin{array}{c}4 / 29 / 94 \\
10 / 05 / 94 \mathrm{~A} \\
0\end{array}\right|$ & $\begin{array}{c}6 / 24 / 94 \\
11 / 11 / 94 \mathrm{~A} \\
0===\end{array}$ & $\begin{array}{r}11 / 18 / 94 \\
2 / 24 / 95\end{array}$ & $\begin{array}{r}12 / 02 / 94 \\
3 / 03 / 95\end{array}$ & $\begin{array}{r}12 / 14 / 94 \\
12 / 14 / 94 \\
-11 \\
\end{array}$ \\
\hline $\begin{array}{l}\text { LP1401 } \\
\text { Carbonizer Alkali Ge } \\
\text { "On Hold" }\end{array}$ & $\begin{array}{c}1 \\
\text { Getter }\end{array}$ & $\begin{array}{l}1161 \mathrm{~A} \\
\text { Out let }\end{array}$ & 116 & & $\begin{array}{r}P \\
A / F\end{array}$ & 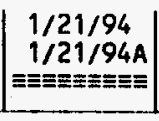 & $\mid \begin{array}{c}2 / 04 / 94 \\
2 / 04 / 94 \mathrm{~A} \\
\equiv \equiv= \pm= \pm= \pm\end{array}$ & $\begin{array}{c}2 / 18 / 94 \\
2 / 18 / 94 \mathrm{~A} \\
\end{array}$ & $\mid \begin{array}{c}3 / 18 / 94 \\
3 / 18 / 94 \mathrm{~A} \\
== \pm\end{array}$ & $\begin{array}{c}4 / 01 / 94 \\
5 / 20 / 94 \mathrm{~A} \\
=\end{array}$ & 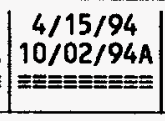 & $\mid \begin{array}{c}4 / 29 / 94 \\
10 / 05 / 94 \mathrm{~A} \\
\equiv= \pm= \pm= \pm\end{array}$ & $\begin{array}{l}6 / 24 / 94 \\
3 / 31 / 95\end{array}$ & $\begin{array}{r}11 / 18 / 94 \\
7 / 21 / 95\end{array}$ & $\begin{array}{r}12 / 02 / 94 \\
7 / 28 / 95\end{array}$ & $\begin{array}{r}2 / 13 / 95 \\
2 / 13 / 95 \\
-24 \\
\end{array}$ \\
\hline $\begin{array}{l}\text { LP1402 } \\
\text { Combustor Alkali Get } \\
\text { "On Hold" }\end{array}$ & $\begin{array}{c}1 \\
\text { etter }\end{array}$ & $\begin{array}{l}1161 \mathrm{~A} \\
\text { Outlet }\end{array}$ & 116 & & $\begin{array}{r}P \\
A / F\end{array}$ & 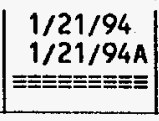 & $\left|\begin{array}{c}2 / 04 / 94 \\
2 / 04 / 94 \mathrm{~A} \\
0=1\end{array}\right|$ & $\begin{array}{c}2 / 18 / 94 \\
2 / 18 / 94 \mathrm{~A} \\
\equiv= \pm \equiv \equiv \equiv \equiv \equiv\end{array}$ & $\left|\begin{array}{c}3 / 18 / 94 \\
3 / 18 / 94 \mathrm{~A} \\
\equiv=\equiv=\equiv \equiv \equiv \equiv\end{array}\right|$ & $\mid \begin{array}{c}4 / 01 / 94 \\
5 / 20 / 94 A \\
\equiv \equiv=\equiv \pm \equiv \equiv\end{array}$ & 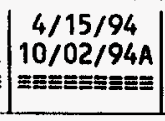 & $\mid \begin{array}{c}4 / 29 / 94 \\
10 / 05 / 94 \mathrm{~A} \\
\equiv \pm= \pm= \pm\end{array}$ & $\begin{array}{l}6 / 24 / 94 \\
3 / 31 / 95\end{array}$ & $\begin{array}{r}11 / 18 / 94 \\
7 / 21 / 95\end{array}$ & $\begin{array}{r}12 / 02 / 94 \\
7 / 28 / 95\end{array}$ & $\begin{array}{r}2 / 13 / 95 \\
2 / 13 / 95 \\
-24 \\
\end{array}$ \\
\hline $\begin{array}{l}\text { LP2501 } \\
\text { Fuel Gas Bypass } \\
\text { Deleted }\end{array}$ & 1 & & & & $\begin{array}{r}P \\
A / F\end{array}$ & & & & & & & & & & & 0 \\
\hline $\begin{array}{l}\text { LP2502 } \\
\text { Vitiated Air Bypass } \\
\text { Deleted }\end{array}$ & & & & & $\begin{array}{r}P \\
A / F\end{array}$ & & & & & & & & & & & 0 \\
\hline $\begin{array}{l}\text { LP2532 } \\
\text { Fuel Gas \& Vitiated } \\
\text { Added "On Hold" }\end{array}$ & Air & Quench Pkg & & & $\begin{array}{r}P \\
A / F\end{array}$ & & & & & & 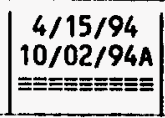 & 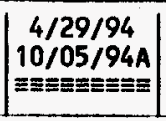 & $\begin{array}{l}6 / 24 / 94 \\
3 / 31 / 95\end{array}$ & $\begin{array}{r}11 / 18 / 94 \\
7 / 21 / 95\end{array}$ & $\begin{array}{r}12 / 02 / 94 \\
7 / 28 / 95\end{array}$ & $\begin{array}{r}5 / 08 / 95 \\
5 / 08 / 95 \\
-12 \\
\end{array}$ \\
\hline $\begin{array}{l}\text { LP2533 } \\
\text { Fuel Gas \& Vitiated } \\
\text { Added "On Hold" }\end{array}$ & Air & Quench Pkg & & & $\begin{array}{r}P \\
A / F\end{array}$ & & & & & & 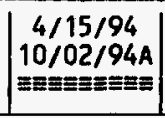 & $\begin{array}{c}4 / 29 / 94 \\
10 / 05 / 94 \mathrm{~A} \\
0= \pm=\equiv=\equiv\end{array}$ & $\begin{array}{l}6 / 24 / 94 \\
3 / 31 / 95\end{array}$ & $\begin{array}{r}11 / 18 / 94 \\
7 / 21 / 95\end{array}$ & $\begin{array}{r}12 / 02 / 94 \\
7 / 28 / 95\end{array}$ & $\begin{array}{r}5 / 08 / 95 \\
5 / 08 / 95 \\
-12\end{array}$ \\
\hline
\end{tabular}

EQUIPMENT LIST CLASS: VALVES

\begin{tabular}{|c|c|c|c|c|c|c|c|c|c|c|c|c|c|c|c|c|}
\hline $\begin{array}{l}\text { VL0262 } \\
\text { Char Valve }\end{array}$ & 1 & $1162 \mathrm{~A}$ & 115 & PP-14 & $\begin{array}{r}P \\
A / F\end{array}$ & 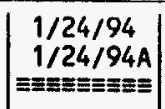 & 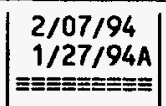 & $\mid \begin{array}{c}2 / 21 / 94 \\
4 / 01 / 94 \mathrm{~A} \\
\equiv \equiv= \pm \equiv \equiv \equiv \equiv\end{array}$ & $\mid \begin{array}{c}3 / 21 / 94 \\
4 / 08 / 94 \mathrm{~A} \\
\equiv=\equiv=\equiv= \pm=\mid\end{array}$ & $\mid \begin{array}{c}4 / 04 / 94 \\
4 / 15 / 94 \mathrm{~A} \\
= \pm= \pm= \pm=0\end{array}$ & $\mid \begin{array}{c}4 / 18 / 94 \\
8 / 26 / 94 \mathrm{~A} \\
=\end{array}$ & 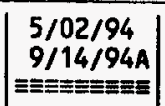 & $\mid \begin{array}{c}6 / 27 / 94 \\
11 / 04 / 94 \mathrm{~A} \\
\end{array}$ & $\begin{array}{r}12 / 09 / 94 \\
3 / 10 / 95\end{array}$ & $\begin{array}{r}12 / 23 / 94 \\
3 / 17 / 95\end{array}$ & $\begin{array}{r}5 / 08 / 95 \\
5 / 08 / 95 \\
7\end{array}$ \\
\hline
\end{tabular}




\begin{tabular}{|c|c|c|c|c|c|c|c|c|c|c|c|c|c|c|c|}
\hline $\begin{array}{l}\text { IIEM } \\
\text { ITEM DESC } \\
\text { Comment }\end{array}$ & SPEC/REQ & INQ \# & PO \# & & $\begin{array}{c}\text { FW } \\
\text { ISSUE } \\
\text { SPEC/ } \\
\text { REQ }\end{array}$ & $\begin{array}{l}\text { SCS } \\
\text { APPROVE } \\
\text { SPEC/ } \\
\text { REQ }\end{array}$ & $\begin{array}{l}\text { FW } \\
\text { ISSUE } \\
\text { INQUIRY/ } \\
\text { RFQ }\end{array}$ & $\begin{array}{l}\text { FW } \\
\text { RECEIVE } \\
\text { BIDS/ } \\
\text { QUDTES }\end{array}$ & $\begin{array}{l}\text { FW } \\
\text { COMPLETE } \\
\text { BID } \\
\text { TABS }\end{array}$ & $\begin{array}{c}\text { SCS } \\
\text { BID } \\
\text { TAB } \\
\text { APPROVAL }\end{array}$ & \begin{tabular}{|c|} 
FW \\
RELEASE \\
PURCHASE \\
ORDER
\end{tabular} & $\begin{array}{c}\text { FW } \\
\text { RECEIVE } \\
\text { VENDOR } \\
\text { DRAWINGS }\end{array}$ & $\begin{array}{l}\text { SHIP } \\
\text { F.o.B. }\end{array}$ & $\begin{array}{l}\text { DELIVERY } \\
\text { TO } \\
\text { SITE/SHOP }\end{array}$ & $\begin{array}{l}\text { F IELD } \\
\text { NEED } \\
\text { SLACK } \\
\text { (IN HKS) }\end{array}$ \\
\hline $\begin{array}{l}\text { VL0263 } \\
\text { Vitiated Air Bypass V } \\
\text { Deleted }\end{array}$ & Ive & & & $\begin{array}{r}P \\
A / F\end{array}$ & & & & & & & & & & & 0 \\
\hline $\begin{array}{l}\text { VL0264 } \\
\text { Fuel Gas Bypass Valve } \\
\text { Deleted }\end{array}$ & & & & $\begin{aligned} P \\
A / F\end{aligned}$ & & & & & & & & & & & 0 \\
\hline $\begin{array}{l}\text { VLO451 } \\
\text { Vitiated Air Valves }\end{array}$ & $1511 \mathrm{~A}$ & 115 & PP. 14 & $\begin{array}{r}P \\
A / F\end{array}$ & $\begin{array}{c}1 / 24 / 94 \\
1 / 24 / 94 \mathrm{~A} \\
\equiv \equiv \equiv \equiv \equiv \equiv \equiv \equiv\end{array}$ & $\begin{array}{c}2 / 07 / 94 \\
1 / 27 / 94 \mathrm{~A} \\
=\equiv \equiv \equiv \equiv \equiv= \pm \equiv\end{array}$ & $\mid \begin{array}{c}2 / 21 / 94 \\
4 / 01 / 94 \mathrm{~A} \\
\equiv \pm \equiv \equiv \equiv \equiv \equiv\end{array}$ & $\begin{array}{c}3 / 21 / 94 \\
5 / 13 / 94 \mathrm{~A} \\
\equiv \equiv \pm \equiv \pm \equiv=\end{array}$ & $\begin{array}{l}4 / 04 / 94 \\
5 / 27 / 94 \mathrm{~A} \\
=\end{array}$ & $\mid \begin{array}{c}4 / 18 / 94 \\
8 / 26 / 94 A \\
\equiv= \pm \equiv=0\end{array}$ & $\mid \begin{array}{l}5 / 02 / 94 \\
9 / 14 / 94 \mathrm{~A} \\
\end{array}$ & $\begin{array}{l}6 / 27 / 94 \\
3 / 10 / 95\end{array}$ & $\begin{array}{r}12 / 09 / 94 \\
6 / 09 / 95\end{array}$ & $\begin{array}{r}12 / 23 / 94 \\
6 / 16 / 95\end{array}$ & $\begin{array}{r}5 / 08 / 95 \\
5 / 08 / 95 \\
-6\end{array}$ \\
\hline $\begin{array}{l}\text { VL0452 } \\
\text { Fuel Gas Valve }\end{array}$ & 15118 & 115 & PP- 14 & $\begin{array}{r}p \\
A / F\end{array}$ & $\begin{array}{c}1 / 24 / 94 \\
1 / 24 / 94 \mathrm{~A} \\
\equiv \equiv \equiv \equiv \equiv \equiv \equiv \equiv=\end{array}$ & $\begin{array}{l}2 / 07 / 94 \\
1 / 27 / 94 \mathrm{~A} \\
=\equiv \equiv \pm \equiv= \pm \equiv=\end{array}$ & $\begin{array}{c}2 / 21 / 94 \\
4 / 01 / 94 \mathrm{~A} \\
=2\end{array}$ & $\begin{array}{c}3 / 21 / 94 \\
5 / 13 / 94 \mathrm{~A} \\
= \pm= \pm= \pm=\mid\end{array}$ & $\begin{array}{c}4 / 04 / 94 \\
5 / 27 / 94 \mathrm{~A} \\
\equiv= \pm= \pm=\end{array}$ & $\begin{array}{c}4 / 18 / 94 \\
8 / 26 / 94 A \\
\equiv \equiv \pm \equiv \equiv \equiv \equiv\end{array}$ & $\begin{array}{l}5 / 02 / 94 \\
9 / 14 / 944 \mathrm{~A} \\
\equiv \equiv \equiv \equiv \equiv \equiv \equiv \equiv \equiv\end{array}$ & $\begin{array}{l}6 / 27 / 94 \\
3 / 10 / 95\end{array}$ & $\begin{array}{r}12 / 09 / 94 \\
6 / 09 / 95\end{array}$ & $\begin{array}{r}12 / 23 / 94 \\
6 / 16 / 95\end{array}$ & $\begin{array}{r}5 / 08 / 95 \\
5 / 08 / 95 \\
-6\end{array}$ \\
\hline
\end{tabular}

EQUIPMENT LIST CLASS: VESSELS - DRUMS

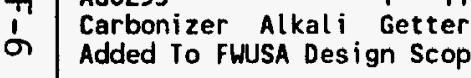

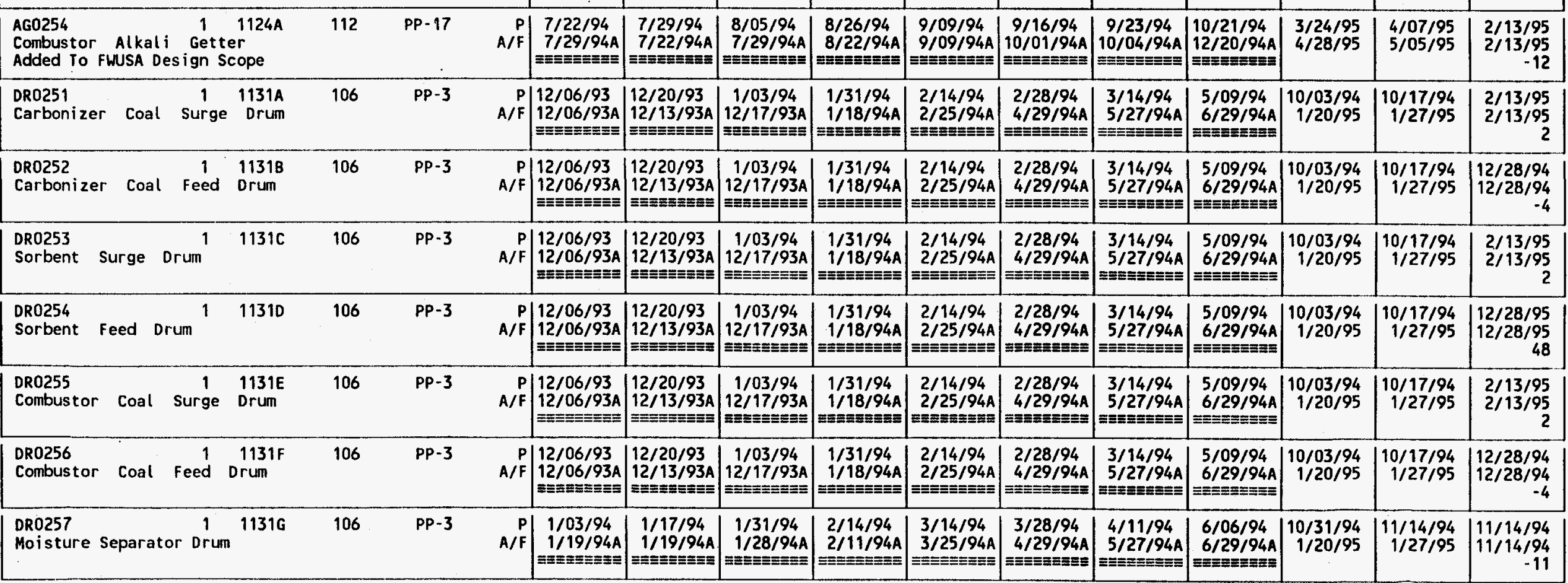


COMPONENI SCHEDULE

EQUIPMENT LIST REVISION DATED - $7 / 19 / 94$
FOSTER WHEELER USA CORP Report SCSOCT File SCSCS.R2D

Page 7

30-Dec- 94

\begin{tabular}{|c|c|c|c|c|c|c|c|c|c|c|c|c|c|c|c|}
\hline $\begin{array}{l}\text { ITEM } \\
\text { ITEM DESC } \\
\text { Comment }\end{array}$ & Y SPEC/REQ & INQ \# & PO \# & & $\begin{array}{c}\text { FW } \\
\text { ISSUE } \\
\text { SPEC/ } \\
\text { REQ }\end{array}$ & $\begin{array}{l}\text { SCS } \\
\text { APPROVE } \\
\text { SPEC/ } \\
\text { REQ }\end{array}$ & $\begin{array}{c}\text { FW } \\
\text { ISSUE } \\
\text { INOUIRY/ } \\
\text { RFO }\end{array}$ & $\begin{array}{c}\text { FW } \\
\text { RECEIVE } \\
\text { BIDS/ } \\
\text { QUOTES }\end{array}$ & $\begin{array}{c}\text { FW } \\
\text { COMPLETE } \\
\text { BID } \\
\text { TABS }\end{array}$ & \begin{tabular}{|c|} 
SCS \\
BID \\
TAB \\
APPROVAL
\end{tabular} & $\begin{array}{c}\text { FW } \\
\text { RELEASE } \\
\text { PURCHASE } \\
\text { ORDER }\end{array}$ & $\begin{array}{c}\text { FW } \\
\text { RECEIVE } \\
\text { VENDOR } \\
\text { ORAWINGS }\end{array}$ & $\begin{array}{l}\text { SHIP } \\
\text { F.O.B. }\end{array}$ & $\begin{array}{l}\text { DEL IVERY } \\
\text { TO } \\
\text { SITE/SHOP }\end{array}$ & $\begin{array}{l}\text { FIELD } \\
\text { NEED } \\
\text { SLACK } \\
\text { (IN WKS) }\end{array}$ \\
\hline $\begin{array}{l}\text { DR0258 } \\
\text { Carbonizer Cyclone } \\
\text { Deleted }\end{array}$ & $1^{1}$ Drain Drum & & & $\begin{array}{r}P \\
A / F\end{array}$ & & & & & & & & & & & 0 \\
\hline $\begin{array}{l}\text { DR0260 A/B } \\
\text { Ash Depressurizat ior }\end{array}$ & $\begin{array}{cc}2 & 1131 \mathrm{~K} \\
\text { on } & \text { Drums }\end{array}$ & 106 & PP-3 & $\begin{array}{r}P \\
A / F\end{array}$ & $\mid \begin{array}{l}12 / 06 / 93 \\
12 / 06 / 93 \mathrm{~A} \\
20=\mathrm{a}\end{array}$ & $\left|\begin{array}{l}12 / 20 / 93 \\
12 / 13 / 93 \mathrm{~A} \\
\equiv \pm \equiv \equiv \pm \equiv \equiv \equiv\end{array}\right|$ & $\mid \begin{array}{c}1 / 03 / 94 \\
12 / 17 / 93 \mathrm{~A} \\
\end{array}$ & $\mid \begin{array}{c}1 / 31 / 94 \\
1 / 18 / 94 \mathrm{~A} \\
\equiv \equiv \equiv= \pm=\equiv\end{array}$ & $\mid \begin{array}{c}2 / 14 / 94 \\
2 / 25 / 94 \mathrm{~A} \\
\equiv=0\end{array}$ & $\begin{array}{c}2 / 28 / 94 \\
4 / 29 / 94 \mathrm{~A} \\
0\end{array}$ & $\mid \begin{array}{c}3 / 14 / 94 \\
5 / 27 / 94 \mathrm{~A} \\
=\end{array}$ & $\begin{array}{c}5 / 09 / 94 \\
6 / 29 / 94 \mathrm{~A} \\
\end{array}$ & $\begin{array}{r}10 / 03 / 94 \\
1 / 20 / 95\end{array}$ & $\begin{array}{l}10 / 17 / 94 \\
1 / 27 / 95\end{array}$ & $\begin{array}{r}12 / 14 / 94 \\
12 / 14 / 94 \\
-6\end{array}$ \\
\hline $\begin{array}{l}\text { DR0264 } \\
\text { Oversize Char Drum }\end{array}$ & $1131 \mathrm{~L}$ & 106 & PP-3 & $\begin{array}{r}P \\
A / F\end{array}$ & $\mid \begin{array}{c}1 / 03 / 94 \\
1 / 19 / 94 \mathrm{~A} \\
\equiv= \pm= \pm \equiv \equiv\end{array}$ & $\mid \begin{array}{c}1 / 17 / 94 \\
1 / 20 / 94 \mathrm{~A} \\
\equiv= \pm \equiv \equiv \equiv \equiv\end{array}$ & $\mid \begin{array}{c}1 / 31 / 94 \\
1 / 20 / 94 \mathrm{~A} \\
\equiv= \pm= \pm= \pm\end{array}$ & 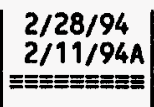 & $\left|\begin{array}{l}3 / 14 / 94 \\
3 / 25 / 94 \mathrm{~A}\end{array}\right|$ & $\mid \begin{array}{c}3 / 28 / 94 \\
4 / 29 / 94 \mathrm{~A} \\
\equiv= \pm\end{array}$ & $\mid \begin{array}{c}4 / 11 / 94 \\
5 / 27 / 94 \mathrm{~A} \\
= \pm=\equiv= \pm\end{array}$ & 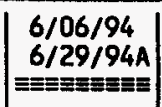 & $\begin{array}{r}10 / 31 / 94 \\
1 / 20 / 95\end{array}$ & $\begin{array}{r}11 / 14 / 94 \\
1 / 27 / 95\end{array}$ & $\begin{array}{r}2 / 13 / 95 \\
2 / 13 / 95 \\
2\end{array}$ \\
\hline $\begin{array}{l}\text { DR0265 } \\
\text { Ash Surge Drum }\end{array}$ & $11131 M$ & 106 & pp-3 & $\begin{array}{r}P \\
A / F\end{array}$ & $\begin{array}{r}1 / 03 / 94 \\
1 / 19 / 94 \mathrm{~A} \\
0=E=E\end{array}$ & $\begin{array}{c}1 / 17 / 94 \\
1 / 19 / 94 \mathrm{~A} \\
\equiv \equiv \equiv \equiv \equiv=\equiv \equiv\end{array}$ & 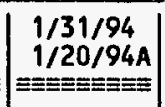 & 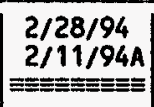 & $\mid \begin{array}{c}3 / 14 / 94 \\
3 / 25 / 94 \mathrm{~A} \\
= \pm \equiv= \pm= \pm= \pm \mid\end{array}$ & $\mid \begin{array}{c}3 / 28 / 94 \\
4 / 29 / 94 \mathrm{~A} \\
0\end{array}$ & $\mid \begin{array}{c}4 / 11 / 94 \\
5 / 27 / 94 \mathrm{~A} \\
5= \pm= \pm= \pm\end{array}$ & $\begin{array}{c}6 / 06 / 94 \\
6 / 29 / 94 \mathrm{~A} \\
\equiv=E\end{array}$ & $\begin{array}{r}10 / 31 / 94 \\
1 / 20 / 95\end{array}$ & $\begin{array}{r}11 / 14 / 94 \\
1 / 27 / 95\end{array}$ & $\begin{array}{r}2 / 13 / 95 \\
2 / 13 / 95 \\
2\end{array}$ \\
\hline
\end{tabular}

EQUIPMENT LIST CLASS: VESSELS - HOPPERS

$\pi$

\begin{tabular}{|c|c|c|c|c|c|c|c|c|c|c|c|c|c|c|c|c|}
\hline $\begin{array}{l}\text { H00252 } \\
\text { Coal Surge Hopper }\end{array}$ & 1 & $1143 A$ & 111 & PP-3 & $\begin{array}{r}P \\
A / F\end{array}$ & 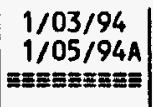 & 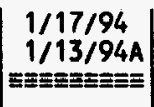 & 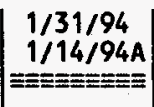 & $\begin{array}{l}2 / 28 / 94 \\
1 / 28 / 94 \mathrm{~A} \\
=\equiv\end{array}$ & $\begin{array}{l}3 / 14 / 94 \\
3 / 04 / 94 \mathrm{~A} \\
3= \pm \equiv \pm=\end{array}$ & 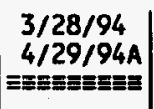 & $\left|\begin{array}{c}4 / 11 / 94 \\
5 / 27 / 94 \mathrm{~A} \\
0\end{array}\right|$ & $\begin{array}{l}6 / 06 / 94 \\
6 / 29 / 94 \mathrm{~A} \\
6 / 29\end{array}$ & $\begin{array}{r}10 / 31 / 94 \\
1 / 20 / 95\end{array}$ & $\begin{array}{r}11 / 14 / 94 \\
1 / 27 / 95\end{array}$ & $\begin{array}{r}8 / 07 / 95 \\
8 / 07 / 95 \\
27\end{array}$ \\
\hline $\begin{array}{l}\text { H00253 } \\
\text { Sorbent Surge Hopper }\end{array}$ & 1 & $1143 \mathrm{~B}$ & 111 & PP-3 & $\begin{array}{r}P \\
A / F\end{array}$ & 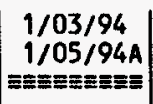 & 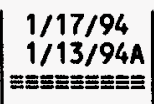 & $\begin{array}{c}1 / 31 / 94 \\
1 / 14 / 94 \mathrm{~A} \\
= \pm=\equiv=\end{array}$ & 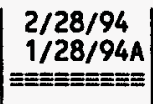 & $\begin{array}{l}3 / 14 / 94 \\
3 / 04 / 94 \mathrm{~A} \\
\end{array}$ & $\begin{array}{c}3 / 28 / 94 \\
4 / 29 / 94 \mathrm{~A} \\
=\end{array}$ & $\left|\begin{array}{c}4 / 11 / 94 \\
5 / 27 / 94 \mathrm{~A} \\
0\end{array}\right|$ & $\begin{array}{c}6 / 06 / 94 \\
6 / 29 / 94 \mathrm{~A} \\
0= \pm= \pm\end{array}$ & $\begin{array}{r}10 / 31 / 94 \\
1 / 20 / 95\end{array}$ & $\begin{array}{r}11 / 14 / 94 \\
1 / 27 / 95\end{array}$ & $\begin{array}{r}5 / 30 / 95 \\
5 / 30 / 95 \\
18\end{array}$ \\
\hline
\end{tabular}

EQUIPMENT LIST CLASS: VESSELS - REACTORS

\begin{tabular}{|c|c|c|c|c|c|c|c|c|c|c|c|c|c|c|c|c|}
\hline $\begin{array}{l}\text { RX0251 } \\
\text { Carbonizer }\end{array}$ & 1 & $1121 \mathrm{~A}$ & 113 & PP-2 & $\begin{array}{r}P \\
A / F\end{array}$ & $\mid \begin{array}{c}1 / 03 / 94 \\
1 / 24 / 94 \mathrm{~A} \\
=\end{array}$ & 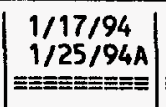 & $\begin{array}{c}1 / 31 / 94 \\
3 / 18 / 94 \mathrm{~A} \\
\end{array}$ & $\begin{array}{c}2 / 28 / 94 \\
4 / 08 / 94 \mathrm{~A} \\
=2\end{array}$ & $\begin{array}{c}3 / 14 / 94 \\
4 / 15 / 94 \mathrm{~A} \\
\end{array}$ & $\begin{array}{c}3 / 28 / 94 \\
4 / 29 / 94 \mathrm{~A} \\
\end{array}$ & \begin{tabular}{c|}
$4 / 11 / 94$ \\
$7 / 01 / 94 \mathrm{~A}$ \\
$\equiv=\equiv \equiv=\equiv$
\end{tabular} & $\left|\begin{array}{c}6 / 06 / 94 \\
8 / 19 / 94 \mathrm{~A} \\
\mid=\equiv\end{array}\right|$ & $\begin{array}{l}2 / 06 / 95 \\
4 / 07 / 95\end{array}$ & $\begin{array}{l}2 / 20 / 95 \\
4 / 14 / 95\end{array}$ & $\begin{array}{r}8 / 07 / 95 \\
8 / 07 / 95 \\
16\end{array}$ \\
\hline
\end{tabular}




\section{APPENDIX G}

WILSONVILLE INTERACTIVE LEARNING SYSTEM:

MWK TRAIN FLOWCHARTS 


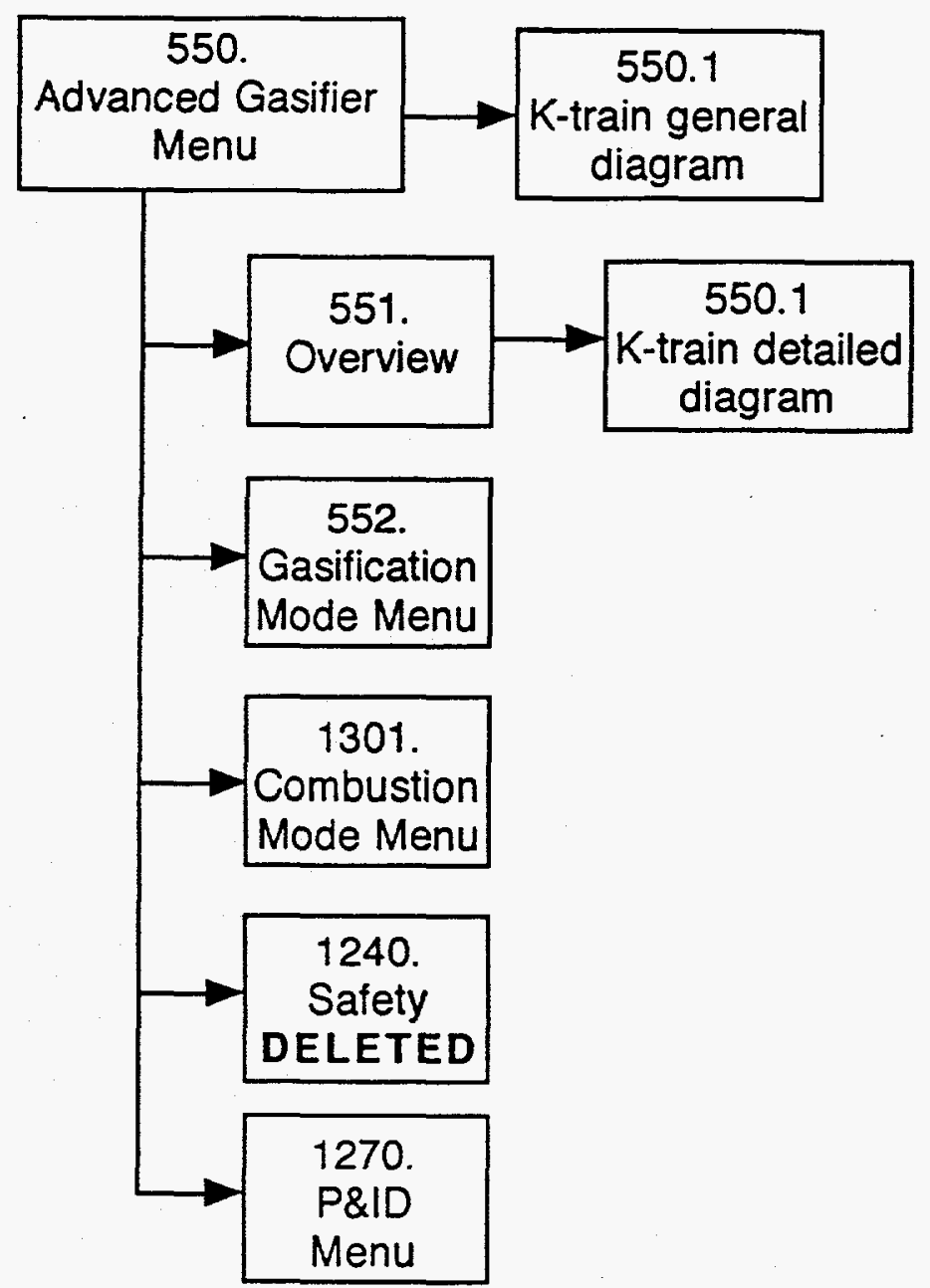


Technology Transfer Modules: flowchart, Advanced Gasifier; Gasification Mode, page 1

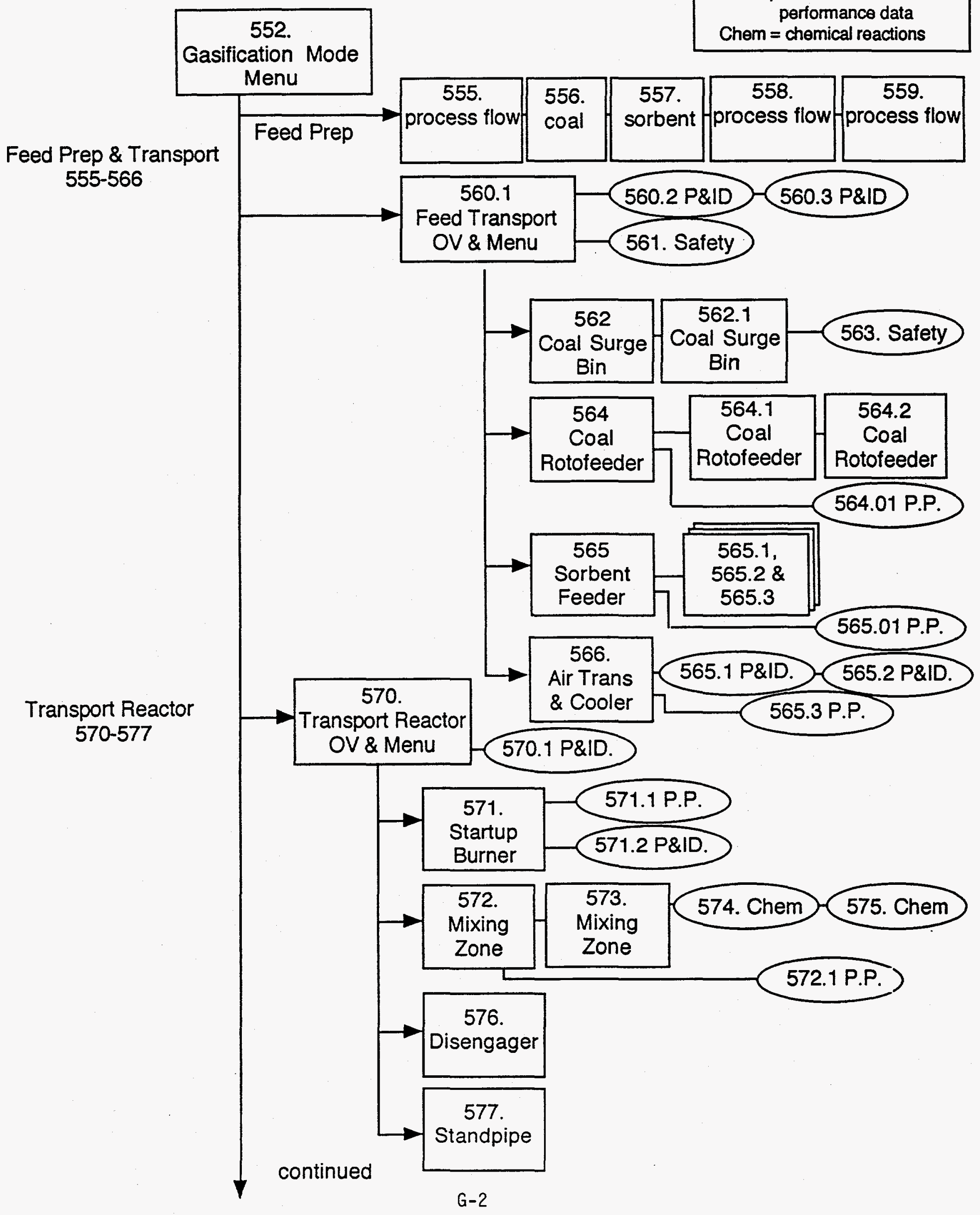


Gas Handling 1215-1227, 580-589

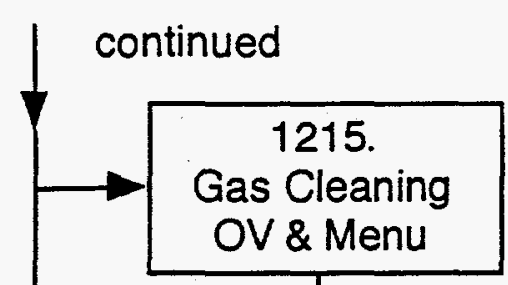

Views $=$ still or stills

P.P. = process performance data

Chem $=$ chemical reactions

1217.1 P\&ID

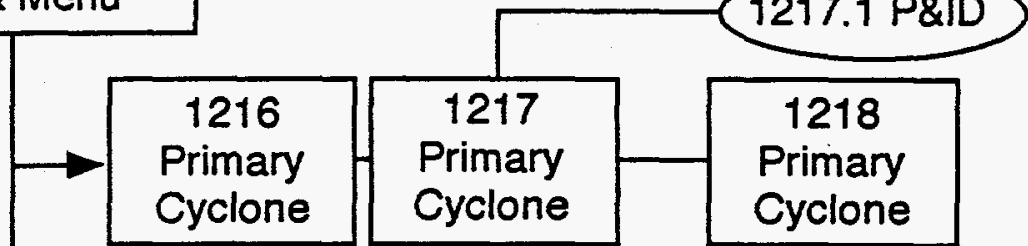

\begin{tabular}{c}
$\rightarrow \begin{array}{c}1219 \\
\text { Primary } \\
\text { Gas Cooler }\end{array}$ \\
\hline $\begin{array}{l}1221 . \\
P C D\end{array}$ \\
\hline
\end{tabular}

1222.

Secondary

Gas Cooler

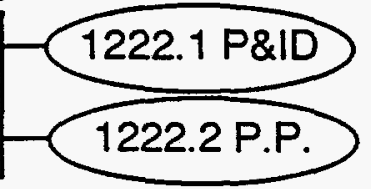

1223.

Fuel Cell

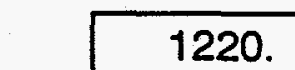

Primary

Gas Cooler

1220.1 P\&ID

1219.1 P.P.
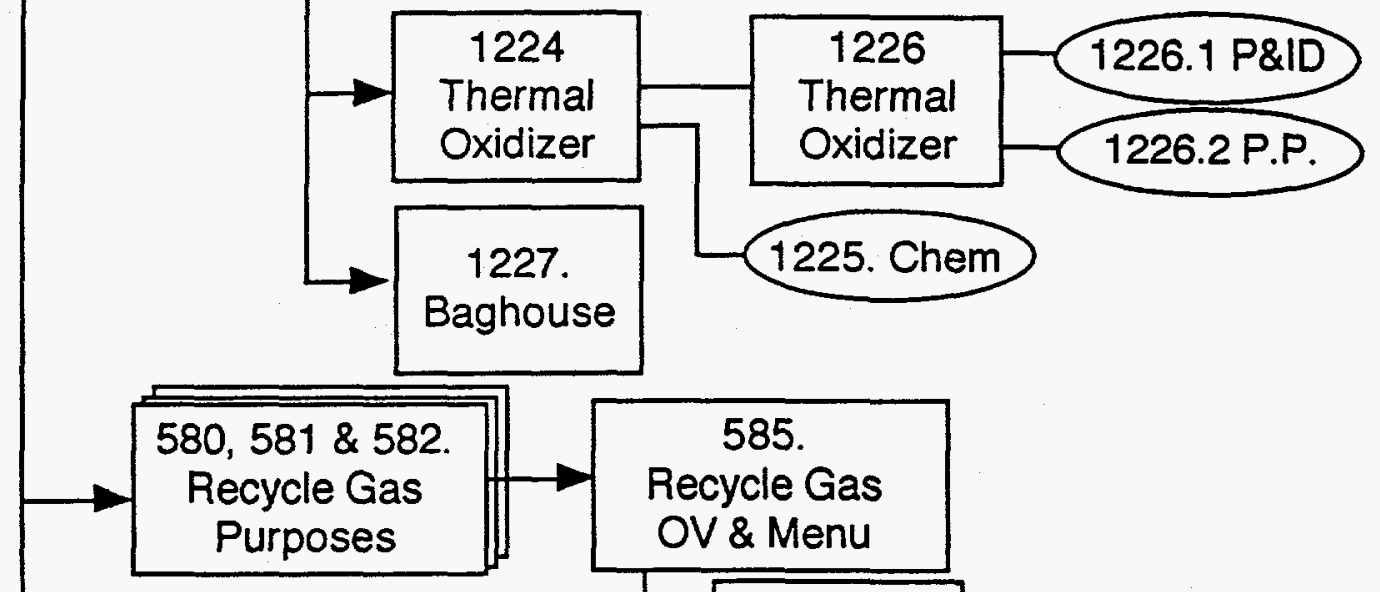

$\downarrow$ continued

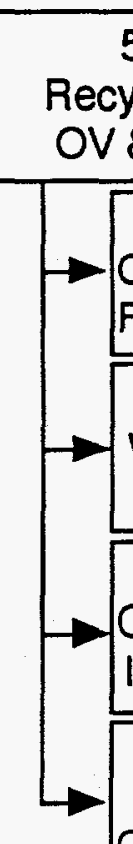

585.

Recycle Gas

OV \& Menu

586.

Compressor

Feed Cooler

587.

Whirl-away

Separator

588.

Compressor

Intake Filter

589.

Booster

Compressor
588.1 P.P. 
Technology Transfer Modules: flowchart, Advanced Gasifier; Gasification Mode, page 3

Solids Handling $590-599,1200-1212$

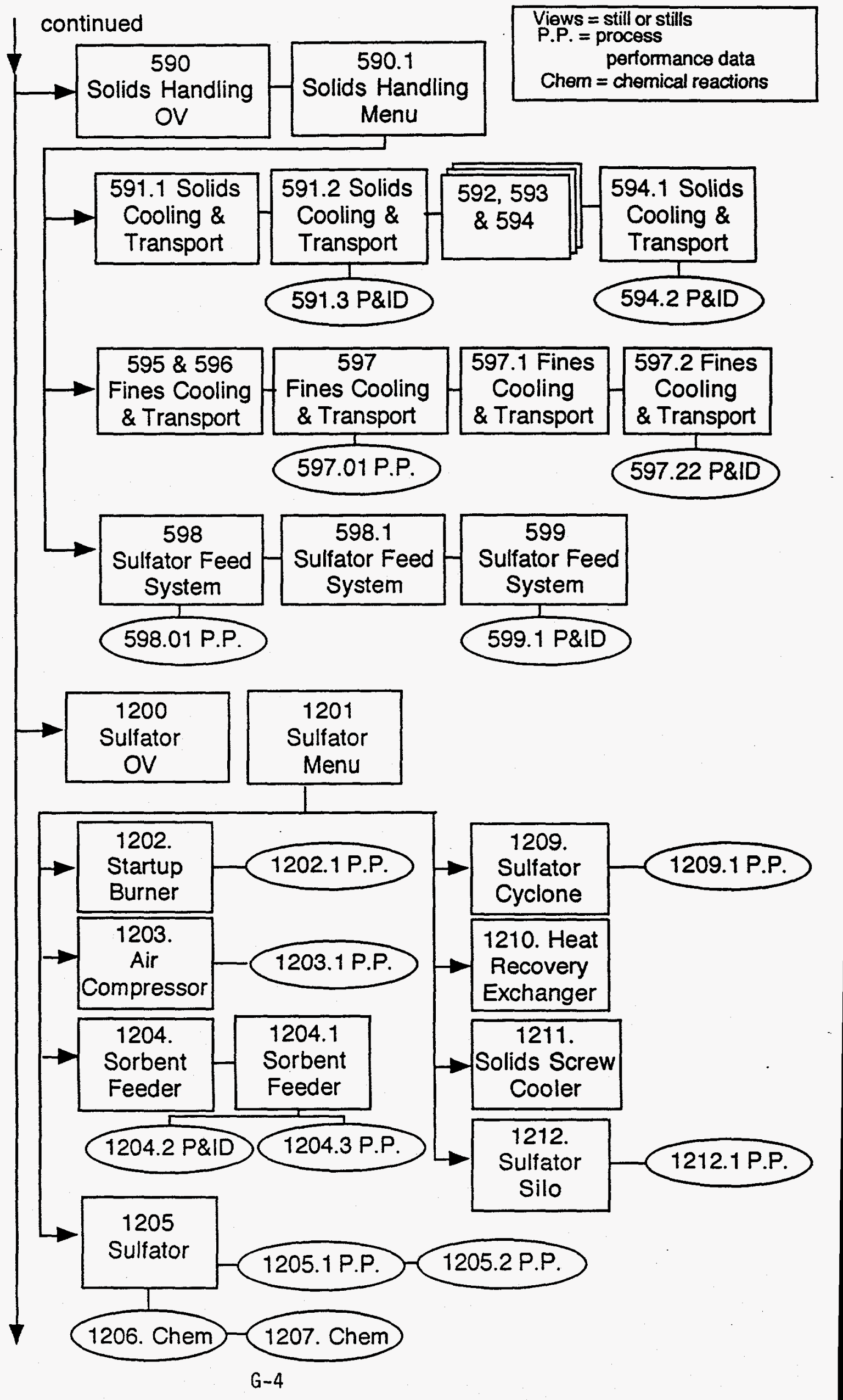


Technology Transfer Modules: flowchart, Advanced Gasifier; Gasification Mode, page 4

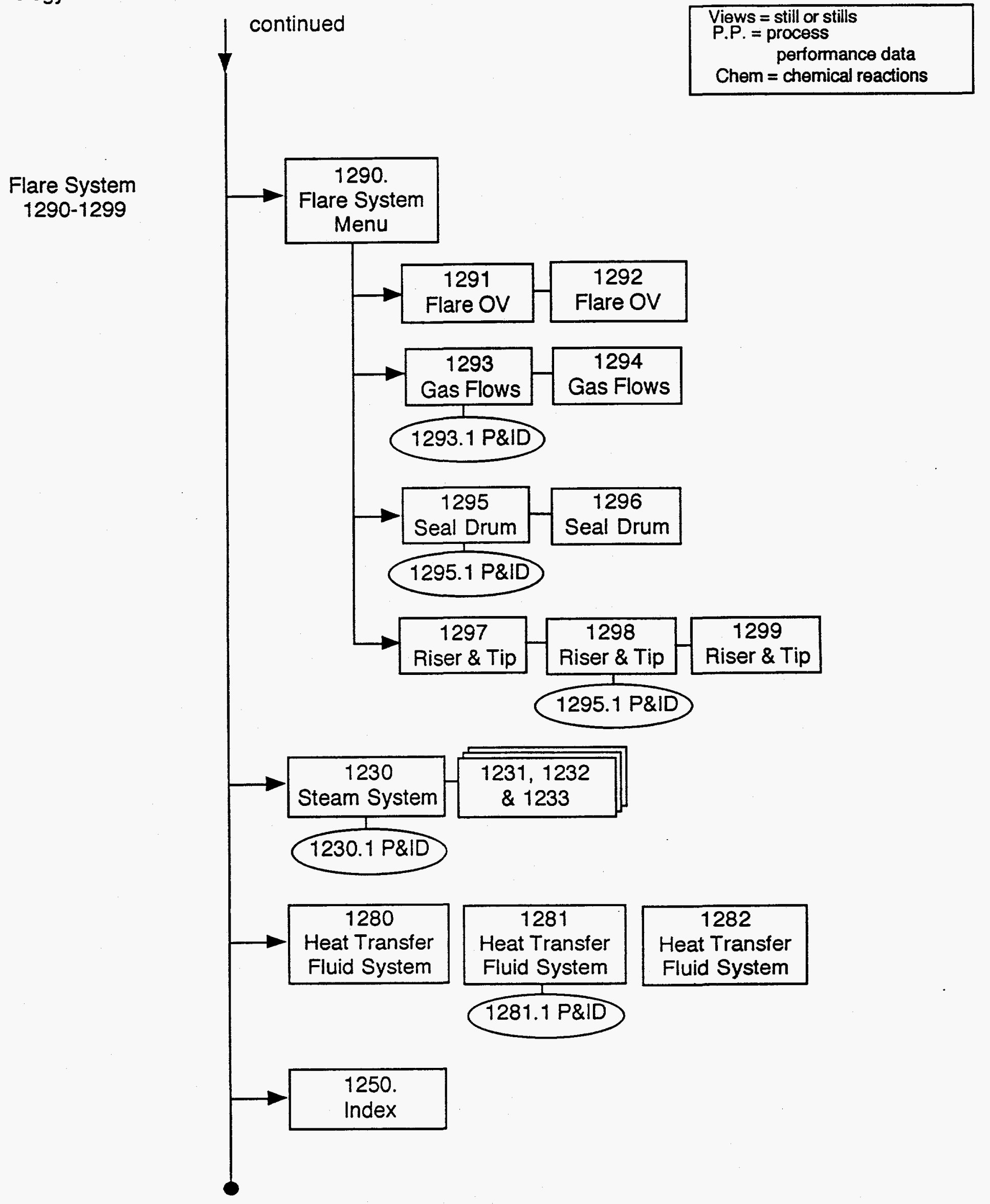




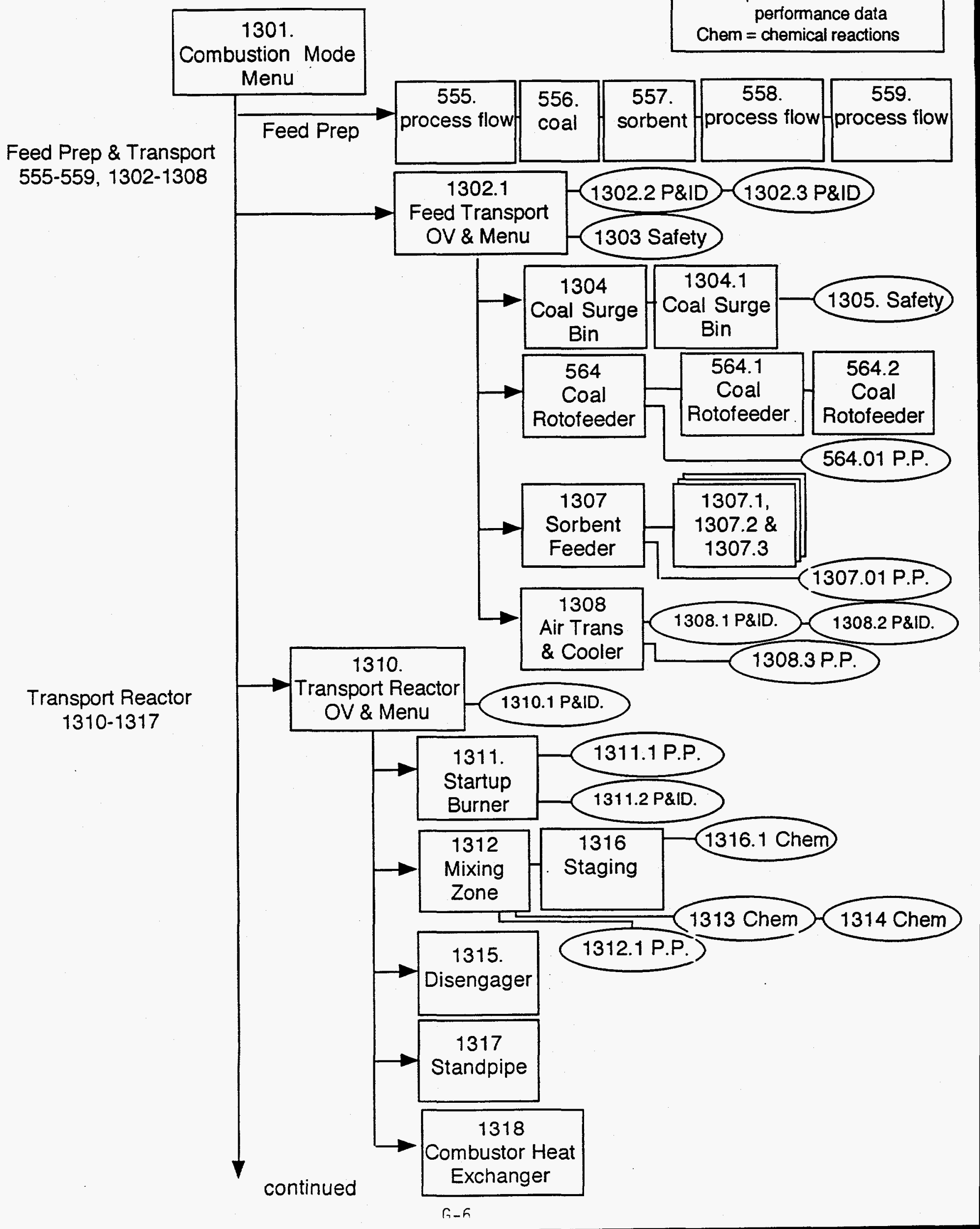

Views $=$ still or stills Views = still or
P.P. = process Chem $=$ chemical reactions

Feed Prep \& Transport $555-559,1302-1308$

Transport Reactor $1310-1317$
1310. OV \& Menu 
Technology Transfer Modules: flowchart, Advanced Gasifier; Combustion Mode, page 2
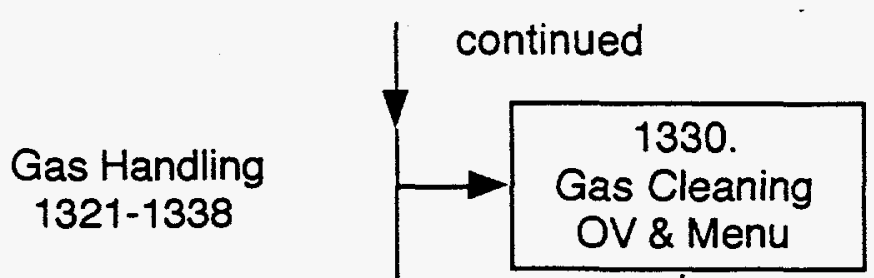

Views $=$ still or stills

Views = still or s
P.P. = process

performance data

Chem $=$ chemical reactions

$1321-1338$

OV \& Menu

1332.1 P\&ID
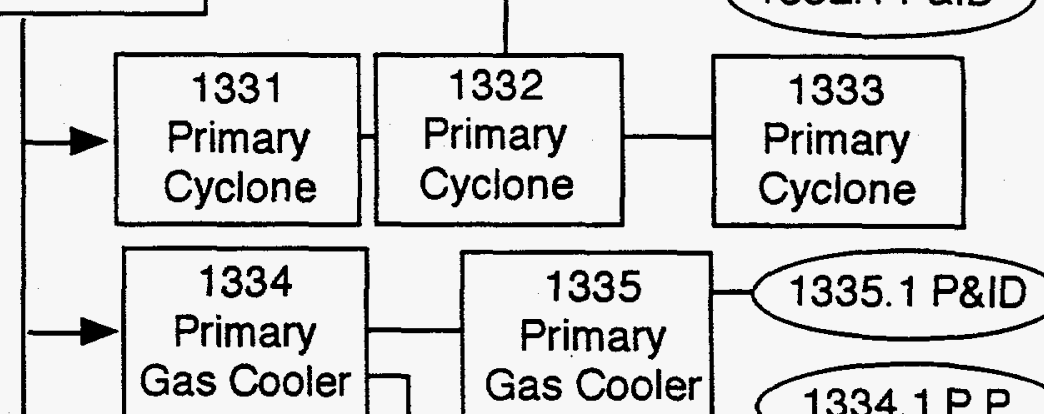

1335

Cyclone
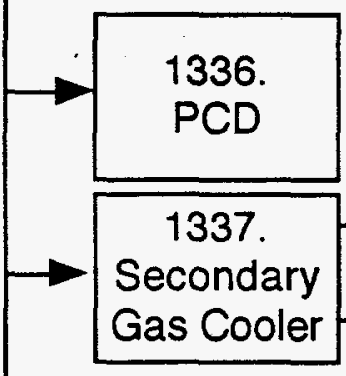

1337.1 P\&ID

1338.

Baghouse

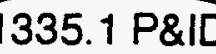

Primary

Gas Cooler

1334.1 P.P.

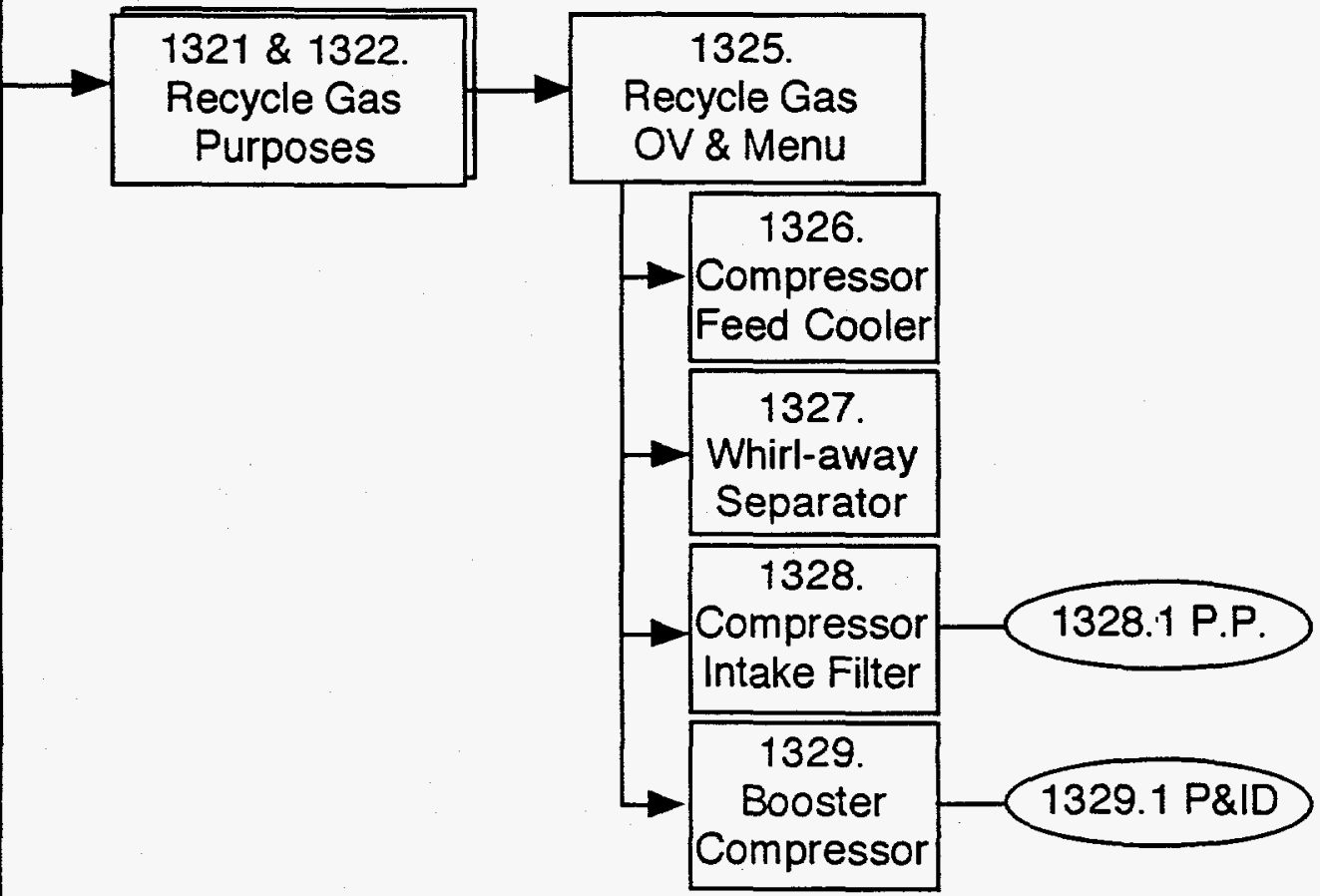

continued 
i echnology Transfer Modules: flowchart, Advanced Gasifier; Combustion Mode, page 3

Solids Handling 1340-1351

Flare System 1290-1299

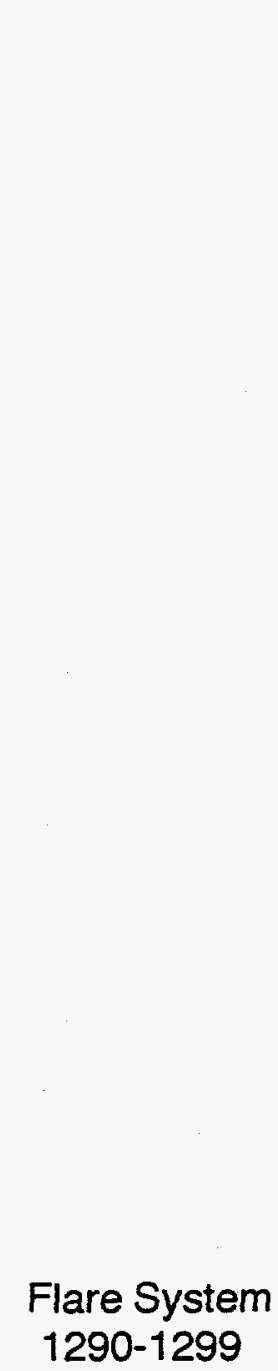

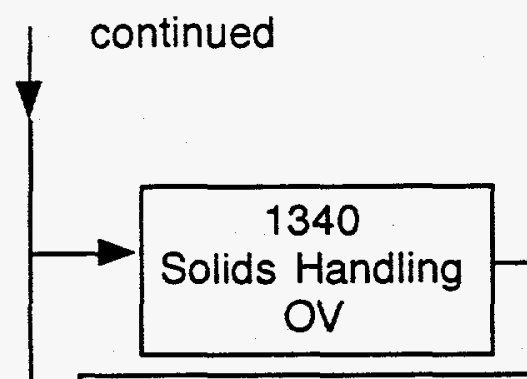

Views $=$ still or stills

P.P. = process

performance data

Chem $=$ chemical reactions

1340.1

Solids Handling

Menu
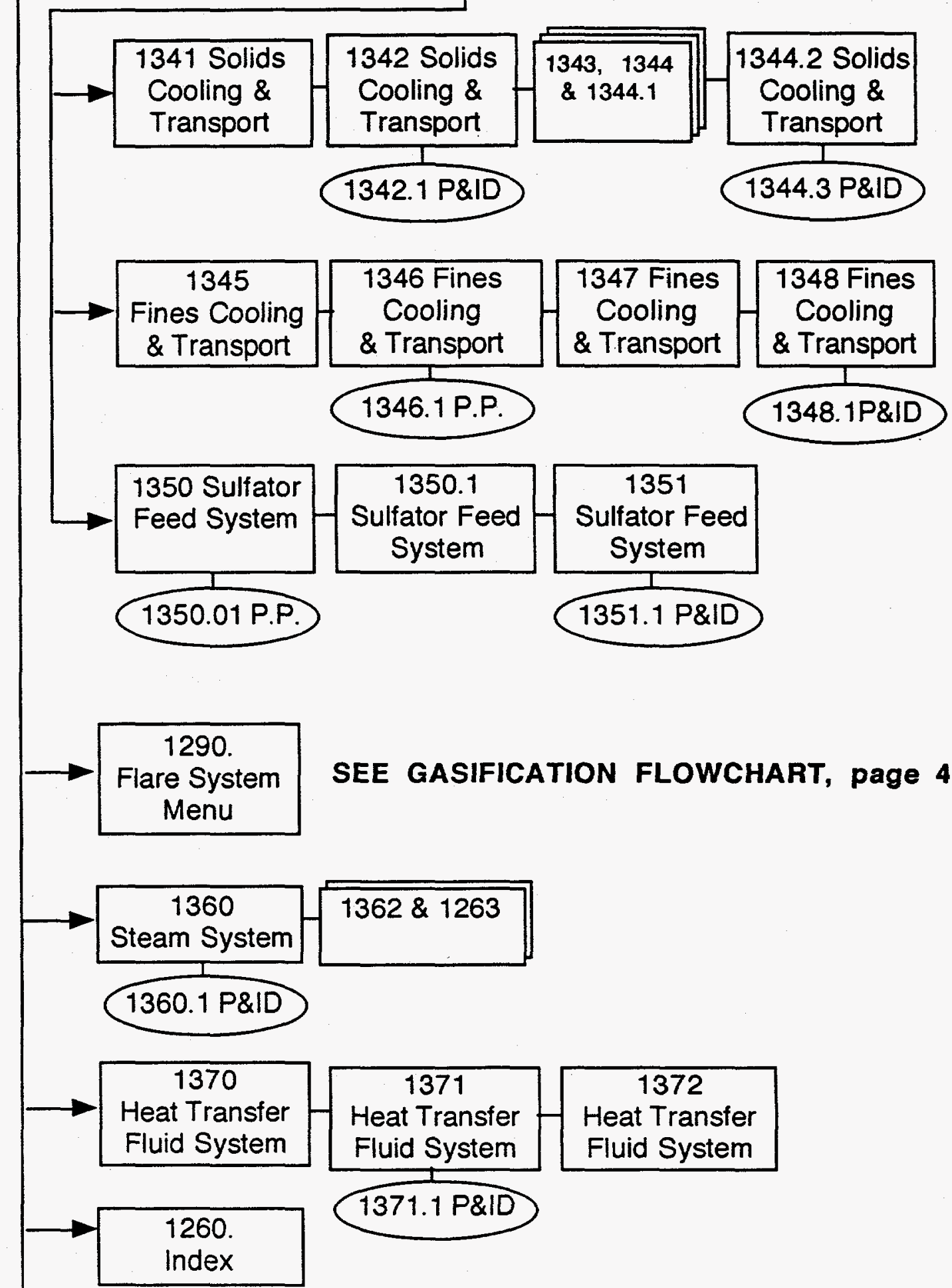

$1362 \& 1263$

44.2 Solids Cooling \& Transport

1344.3 P\&ID 